\title{
COBRANÇA PELO USO DA ÁGUA E ESCASSEZ DE RECURSOS HÍDRICOS: \\ Proposta de Modelo de Cobrança \\ e AplicaÇão na Bacia do Rio Atibaia
}

\section{Aurélio Teodoro Fontes}

Tese apresentada à Escola de Engenharia de São Carlos da Universidade de São Paulo, como parte dos requisitos para obtenção do título de Doutor em Ciências da Engenharia Ambiental.

ORIENTADOR: Prof. Titular Marcelo Pereira de Souza 
Fontes, Aurélio Teodoro

Cobrança pelo uso da água e escassez de recursos hídricos : proposta de modelo de cobrança e aplicação na bacia do rio Atibaia / Aurélio Teodoro Fontes. -- São Carlos, 2003.

Tese (Doutorado) -- Escola de Engenharia de São Carlos-Universidade de São Paulo, 2003.

Área: Ciências da Engenharia Ambiental.

Orientador: Prof. Tit. Marcelo Pereira de Souza.

1. Cobrança pelo uso da água.

2. Instrumento econômico de gestão ambiental. 3. Gestão de recursos hídricos. I. Título. 
“... o importante é que decisões ecológicas e éticas determinem os preços, não o contrário..."

Herman Daly 
Dedico às minhas companheiras de todas as horas, Bruna e Jô, e à Marina que está por chegar. 


\section{Agradecimentos}

Ao professor Marcelo Pereira de Souza por mais esta orientação e, muito mais, pelo contínuo apoio à minha formação profissional.

Aos amigos que caminharam e ainda caminham nesta jornada.

A todos os colegas que contribuíram para a realização deste trabalho, em especial ao Kaito, ao Giovanni è à Celimar.

À minha família sempre presente.

Ao Prof. Rubem La Laina Porto e ao Alexandre do LabSid / EPUSP.

Ao CRHEA e ao Departamento de Hidráulica e Saneamento pela estrutura.

E ao CNPq pela bolsa de estudo. 


\section{Sumário}

Lista de Figuras

Lista de Tabelas

Resumo

Abstract

1. Introdução ..................................................................................... 1

2. Objetivos ...................................................................................... 6

3. Revisão da Literatura …........................................................................... 7

3.1. Gestão Ambiental .................................................................................. 7

3.1.1 Gestão de Recursos Hídricos ............................................................ 11

3.1.2 Cobrança pelo Uso da Água ......................................................... 17

3.2. Escassez de Água e Cobrança ................................................................... 23

3.2.1 O Caso da França .............................................................................. 29

3.2.1.1 Formação do valor cobrado na França ................................... 32

3.2.2 O Caso da Alemanha ..................................................................... 35

3.2.2.1 Formação do valor cobrado na Alemanha ............................. 37

3.2.3 Experiência Brasileira: o caso do Ceará ............................................ 40

3.2.3.1 Formação do valor cobrado no Ceará .................................... 42

4. Material e Métodos ................................................................................. 47

4.1 Metodologia de Cobrança .................................................................... 48

4.1.1 Cobrança sobre Lançamento de Poluentes ........................................ 48

4.1.2 Cobrança sobre Consumo de Água ................................................. 51

4.2 Capacidade de Pagamento ................................................................ 52

4.2.1 Setor Agrícola ............................................................................. 54

4.2.2 Setor Industrial .................................................................... 57 
4.3 Modelagem Matemática

4.3.1 Modsimp 32

4.3.2 Aplicação do Modsimp 32 ........................................................... 62

5. Modelo de Cobrança Proposto ...................................................................... 66

5.1 Cobrança sobre Lançamento de Poluentes ........................................... $\quad 70$

5.2 Cobrança sobre Captação de Água......................................................... 76

5.2.1 Qualidade determinada pela Vazão Mínima...................................... 77

5.2.2 Qualidade determinada pela Poluição.............................................. 79

5.2.3 Qualidade: análise comparativa Vazão Mínima x Poluição................ 79

6. Aplicação do Modelo: Resultados e Discussão................................................ 82

6.1 Caracterização da Área de Estudo ......................................................... 83

6.2 Resultados Obtidos e Discussão........................................................... 87

6.2.1 Primeiro cenário: captação de água com pouca escassez................. 89

6.2.1.1 Cenário em ambiente MODSIM......................................... 91

6.2.2 Segundo cenário: captação de água e lançamento de efluente......... 94

6.2.3 Terceiro cenário: captação e poluição com escassez de água........... 98

6.2.4 Quarto cenário: transposição de bacias......................................... 100

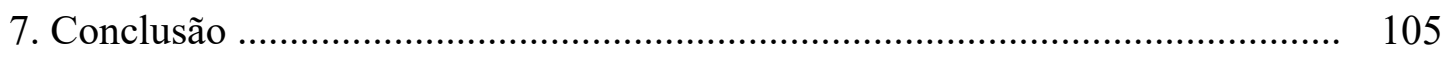

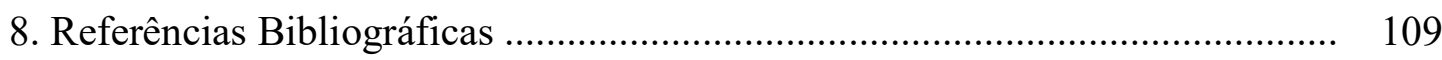




\section{Lista de Figuras}

Figura 3.1 - Sistema de gestão ambiental …................................................... 8

Figura 3.2 - Objetivo da cobrança ...................................................................... 27

Figura 4.1 - Curva para cobrança ….................................................................. 49

Figura 4.2 - Quadro demonstrativo de resultados ......................................... 58

Figura 4.3 - Balanço financeiro de empresa têxtil ............................................ 58

Figura 4.4 - Representação de uma rede de fluxo ................................................. 61

Figura 4.5 - Compartimentos ambientais da sub-bacia Atibaia .......................... 63

Figura 4.6 - Rede de fluxo da bacia do Atibaia ................................................... 64

Figura 4.7 - Postos fluviométricos da bacia do rio Piracicaba .......................... 65

Figura 5.1 - Curva para cobrança ................................................................ $\quad 74$

Figura 5.2 - Formulação do modelo de cobrança proposto …............................. 80

Figura 6.1 - Localização da área de estudo ....................................................... 83

Figura 6.2 - Localização da bacia do rio Piracicaba ............................................ 84

Figura 6.3 - Esquema da rede de fluxo relativo à porção da bacia do Atibaia ..... 88

Figura 6.4 - Curva de permanência de trecho da bacia dada pelo MODSIM ....... 88

Figura 6.5 - Tela do MODSIM com destaque para a planilha de cobrança ......... 92

Figura 6.6 - Detalhe exemplificando planilha de cobrança no MODSIM ............ 94 


\section{Lista de Tabelas}

Tabela 4.1 - Curvas de custos totais de sistemas de tratamento de efluentes e equações da curva para cobrança

Tabela 4.2 - Consumo anual de água por cultura na bacia do rio Atibaia ............ 56

Tabela 4.3 - Capacidade de pagamento por cultura na bacia do rio Atibaia referente ao gasto de $90 \%$ da renda com subsistência famíliar

Tabela 4.4 - Demandas na bacia do Atibaia - ano 2010 64

Tabela 6.1 - Dados de SMA (1994), Azambuja (2000) e Righetto (2001)

Tabela 6.2 - Análise do índice de qualidade para captação de água no C.ITA ......

Tabela 6.3 - Preço por unidade de água e total arrecadado do usuário no C.ITA... 97

Tabela 6.4 - Análise do índice de qualidade para captação de água no C.PAN .... 98

Tabela 6.5 - Preço por unidade de água e total arrecadado do usuário no C.PAN.. 99

Tabela 6.6 - Cenários com dados de saturação do rio, vazão do rio e vazão captada da bacia do Piracicaba para a RMSP

Tabela 6.7 - Preços por unidade de água e totais arrecadados por ano do modelo proposto e respectivos totais do modelo base 


\section{Resumo}

No Brasil, a Política Nacional de Recursos Hídricos apresenta a cobrança pelo uso da água como um instrumento de gestão de recursos hídricos de caráter econômico. Considerando esse caráter, a cobrança deve ter como objetivos: racionalizar o uso do recurso baseado na sua escassez; reconhecer a água como um bem de valor econômico, refletindo os custos ambientais advindos de sua utilização; e diminuir os conflitos entre os usos, induzindo uma alocação que considere o gerenciamento da demanda e as prioridades da sociedade.

Além dessas metas, como instrumento de gestão de uma política que lista como primeiro objetivo "assegurar à atual e às futuras gerações a necessária disponibilidade de água, em padrões de qualidade adequados aos respectivos usos", a cobrança deve ser implementada de maneira que o agente usuário direcione seu comportamento no sentido da sustentabilidade ambiental.

Mediante esses fundamentos, o que se pretende desenvolver neste trabalho é a aplicação de um modelo de cobrança sobre o uso da água que considera como princípio base a manutenção da qualidade ambiental medida pela adequada gestão da escassez de água e, compondo a busca dessa qualidade, a racionalização econômica e a viabilização financeira. Essa predominância do ambiente sobre aspectos econômicos vem no sentido de desqualificar argumentos segundo os quais, os impactos advindos dos usos da água serão corrigidos indefinidamente mediante investimentos financeiros em infra-estrutura. Admitir que o desenvolvimento tem esse poder é supor equivocadamente que o meio econômico é limitante do meio ambiente e não o contrário.

Esta constatação mostra qual é o problema da maioria das propostas de cobrança que valoram a água baseadas em custos de tratamento de resíduos e de 
obras hidráulicas. Por mais elaborados que sejam essas fórmulas de cobrança, chegando a ponto de se conseguir que fique mais caro, mediante um padrão ambiental corretamente definido, captar água ou lançar poluentes do que racionalizar usos, o preço da água não pode estar baseado em fatores cuja "sustentabilidade" pode acabar no curto prazo, dependendo do ritmo de crescimento econômico.

A sustentabilidade dos recursos hídricos só será base da cobrança pelo uso da água se o valor cobrado for dificultando esse uso à medida que os recursos tornarem-se escassos, e não quando os custos de medidas mitigadoras dessa escassez se tornarem excessivamente elevados. Portanto, o modelo de cobrança proposto neste trabalho procura garantir que o agente econômico que está exaurindo o meio ambiente não possa ter capacidade de pagar por essa degradação, ajudando efetivamente a política de outorga do direito de uso da água na observância da capacidade de suporte do meio.

Palavras-chave: cobrança pelo uso da água; instrumento econômico de gestão ambiental; gestão de recursos hídricos. 


\section{Abstract}

In Brazil, the Water Resources National Policy incorporates the water pricing as an economic tool for water resources management. Considering this definition, the water pricing must accomplish the following objectives: to promote the efficient use of the resource considering its shortage; to recognize the water as a good (commodity) with economic value, internalizing the environmental costs of externalities originated from the use of water resources; to reduce the conflicts of water use through an allocation system which balance the society priorities with the water demand management.

The water pricing is included as a management tool in a policy whose primary objective is to "ensure water availability for current and future generations with suitable quality standards according to its respective uses". So besides the goals mentioned above, the water pricing must be implemented in a way to induce the user to behave towards the environmental sustainability.

Based on these fundamentals, this research presents the conceptualization and application of a pricing model for water use that considers the principle of environmental efficiency evaluated by the adequate management of the water shortage. Following the environmental efficiency, the model also pursues the economic and financial efficiency of the water resource system. This predominance of the environment over the economy weakens arguments that the water use impacts would be compensated indefinitely by financial investments in infrastructure. To admit that economic development has this power is similar to mistakenly assume that the economic dimension is the limit for the environment, and not the opposite.

This argument clarifies the problem of the majority of the water pricing methodologies, which define the value of water based on wastewater treatment costs and on hydraulic construction costs. Even if these pricing methods are very well 
defined, in a way that they define prices for water diversion or wastewater discharges higher than prices for rational use, the price of water cannot be based on indicators whose sustainability may end in the short time, in accordance with the economic growth.

The sustainability of the water resources as fundamental for the water pricing will be accomplished when the price charged for the water reflects the shortage of the resources, and not the cost for mitigation measures. So, the water-pricing model proposed in this research tries to guarantee that the economic agent who is degrading the environment will not be able to pay for the costs of this degradation.

Keywords: water pricing; economic tool for environmental resources management; water resources management. 


\section{Introdução}

O Homem está utilizando os recursos naturais para o desenvolvimento econômico de maneira cada vez mais acelerada. A escala temporal da natureza, muitas vezes, não consegue acompanhar o ritmo do avanço tecnológico que degrada o ambiente e o esgotamento dos recursos torna-se inevitável mesmo para aqueles considerados renováveis. As pessoas precisam pensar o mundo de modo a conciliar o bem estar humano com a limitação do meio ambiente, a fim de que o desenvolvimento responsável pelo ganho de qualidade de vida seja duradouro. Como boa parte da sociedade vem percebendo esse contexto, surgiram conceitos como ecodesenvolvimento e desenvolvimento sustentável.

Desde o começo da década de setenta, época da Conferência em Ambiente Humano de Estocolmo, pensadores ligados a programas das Nações Unidas como Maurice Strong e Inacy Sachs, observando comunidades rurais, fundamentaram aquilo que seria o "ecodesenvolvimento", conceito de desenvolvimento que deveria condicionar a dinâmica econômica à qualidade do ambiente e à inclusão social. De forma mais específica, segundo Vieira (1995), Inacy Sachs, no ano de $1974^{*}$, propôs um modelo de crescimento econômico descentralizado, participativo, respeitador da sustentabilidade ecológica e indutor da justiça social.

A partir da década de oitenta, esse novo conceito de desenvolvimento foi ampliado e tem se popularizado através da expressão "desenvolvimento sustentável", cuja definição mais difundida é a dada pela Comissão de Meio Ambiente e Desenvolvimento da Organização das Nações Unidas (World Commission on Environment and Development - WCED, 1987): “o desenvolvimento sustentável é aquele que atende às necessidades do presente sem comprometer a possibilidade de

\footnotetext{
${ }^{*}$ Sachs, I. Environnement et styles de développement. Annales. V.3, p.533-570, 1974.
} 
as gerações futuras atenderem as suas próprias necessidades". Entretanto, em Elliot (1994), já encontra-se referência a outra definição desse termo em trabalho de $1980^{*}$ : “desenvolvimento apropriado para satisfazer de maneira permanente às necessidades do Homem e conseguir a melhoria da qualidade da vida humana".

$\mathrm{Na}$ tentativa de viabilizar este novo paradigma, estão sendo criadas políticas ambientais, cujos objetivos são fazer com que as atividades antrópicas tenham como resultado o máximo possível de ganho em qualidade de vida com respectivo impacto ambiental negativo mínimo. Dentre essas políticas, ressalta-se a importância das políticas de recursos hídricos, que ocupam posição estratégica ao se pensar o desenvolvimento devido à condição de escassez de água. Afinal, a escassez pode inviabilizar o uso da água e tornar-se fator limitante das metas de um plano de desenvolvimento.

A pouca disponibilidade de recursos hídricos é conseqüência da degradação dos corpos d'água, representada, por exemplo, pelo assoreamento, pela contaminação por compostos tóxicos e pela diminuição da capacidade de autodepuração quando da diminuição da vazão através de captação. Como resultado imediato, a perda da qualidade dos recursos hídricos para usos mais nobres e o aumento do potencial para ocorrência de conflitos entre os usos múltiplos de recursos hídricos. Mediante essa realidade, faz-se necessária a existência de instrumentos eficientes e maneiras de atuação que visem administrar e solucionar esses problemas.

Surgem, então, na legislação brasileira, os instrumentos da Política Nacional de Recursos Hídricos (instituída pela Lei Federal $n^{\circ}$ 9.433/97) e, dentre eles, a cobrança pelo uso de recursos hídricos, instrumento fundamentado no caráter limitado desse recurso natural e, como conseqüência, na existência de um valor econômico para a água.

No Brasil, assim como em grande parte do mundo, o ar que se respira ou a água que se bebe dos rios são culturalmente encarados pela sociedade como bens naturalmente disponíveis. Para o indivíduo comum, esse cenário ainda é realidade enquanto esses usos não representarem risco à saúde. Entretanto, esse raciocínio não pode ser aplicado diretamente para usos em escalas maiores. Em função do aumento

\footnotetext{
* Allen, R. How to save the World. London: Kogan Page, 1980.
} 
vertiginoso do uso de recursos naturais no último século, não se pode utilizá-los de forma indiscriminada sem que seja considerada a escassez imposta pelo meio ambiente. Alguma forma de gestão se faz necessária para tornar o uso desses recursos sustentável, principalmente sobre aqueles agentes cuja escala de utilização superam largamente o simples ato de respirar ou beber.

Neste contexto, o termo gestão pode ser traduzido como administração ou gerenciamento de um conjunto de ações, que devem ser fruto de um plano estabelecido a partir de determinados objetivos. Sintetizando, a política estabelece metas a serem racionalizadas pelo planejamento cujo resultado, o plano de ação, é executado na gestão. O adjetivo "ambiental" pode acompanhar estes termos, qualificando-os quanto à preocupação em preservar a qualidade do meio ambiente.

A cobrança pelo uso da água, instrumento de gestão ambiental, já é utilizada em diversos países, mas sua concepção necessita ser cuidada a fim de que sejam alcançados seus objetivos. A motivação para o surgimento da cobrança já indica quais devem ser esses objetivos, e a tradução de sua função num sistema de gestão ambiental mostra qual sua principal tarefa, a saber: contribuir (papel do instrumento) na administração (sinônimo de gestão) de conjunturas ambientais desfavoráveis (próprio do adjetivo ambiental).

No entanto, a complexidade do ambiente exige que todos os instrumentos integrem-se para a gestão desses problemas conjunturais. A degradação ambiental também ocorre em função da falta de ordenamento do uso e ocupação do solo, de uma ineficiente coordenação entre as atividades de licenciamento ambiental e outorga de direito de uso da água (no caso, outorga para lançamento de efluentes) e devido à ausência de informações sobre os níveis de poluição e contaminação existentes, ou seja, devido à não utilização adequada de instrumentos de gestão, mesmos os já previstos em lei.

A regulamentação da Política Nacional de Recursos Hídricos demanda a utilização de instrumentos técnicos e científicos inovadores, a fim de viabilizar a imediata implementação e operacionalização do sistema de gestão vislumbrado. Assim, a organização do arcabouço institucional e legal e a utilização de instrumentos de gestão de recursos hídricos, entre eles a cobrança pelo uso da água, 
ganham destaque na busca da solução dos conflitos pelo uso da água, objetivo da política e do planejamento ambientais.

Existe, ainda, um fator a considerar na implementação da cobrança que a diferencia dos outros instrumentos: ela é um instrumento econômico de gestão ambiental. Segundo Livingston (1995), implementar a cobrança, mecanismo inicialmente adaptado ao mercado, requer a absorção das características da água que trariam distorções mercadológicas ao sistema de cobrança. Sendo a água um "produto" de transporte e armazenamento dispendiosos, cuja disponibilidade para uns depende da utilização por outros e com incertezas associadas à sua natureza, como quantidade e qualidade sazonais, a alocação ótima desejada pelo sistema necessita da construção de cenários que ofereçam aos usuários algum grau de certeza da disponibilidade deste produto.

A modelagem matemática pode contribuir na formulação destes cenários, fornecendo a quantificação das interferências entre os usos da água, as possibilidades advindas do manejo de reservatórios e a probabilidade de ocorrência de determinados cenários desejados. A modelagem diminui a subjetividade do sistema de cobrança, fornecendo às instituições de gerenciamento condições de "aprimoramento do produto água". Além disso, ao possibilitar a avaliação da disponibilidade hídrica, fundamental na análise de impactos ambientais e em programas e decisões de aproveitamento múltiplo e integrado da água, a modelagem ajudará a integrar os instrumentos de gestão ambiental.

A construção de cenários futuros para avaliação da disponibilidade de água também poderá indicar o crescimento da demanda por recursos hídricos acompanhando o nível de desenvolvimento econômico, bem como o crescimento populacional. Desta maneira, a cobrança poderá ajudar no equacionamento do problema de escassez de água juntamente com planos de gerenciamento de demanda que visem ao redirecionamento dos padrões de consumo. Em verdade, somente mediante este diagnóstico é que a cobrança pelo uso da água poderá ter como base valores inibidores desse uso baseados na capacidade do ambiente em sustentá-lo.

A escala ambiental deve prevalecer sobre a escala humana quando avaliada a escassez de recursos naturais. Assim, a cobrança pelo uso dos recursos hídricos, que 
deve basear-se nessa escassez, não pode seguir uma lógica diferente dessa. A cobrança só alcançará seu objetivo se o valor cobrado não ficar ancorado no custo de desenvolvimento de tecnologias e de execução de obras de correção dos impactos negativos advindos do crescimento econômico. Como se depreende de Costanza (1991), um instrumento econômico de gestão ambiental que vise à sustentabilidade do desenvolvimento só obterá sucesso se observar a dependência dos sistemas econômicos aos sistemas ecológicos, visto que estes últimos são maiores e limitantes ao desenvolvimento dos primeiros.

A ressalva quanto ao alcance da cobrança é importante à medida que sua utilização vem sendo direcionada muito mais para a mitigação de problemas do que para a prevenção. Se analisadas as experiências de cobrança existentes, como fizeram diversos autores ${ }^{*}$, nota-se que elas fogem do conceito daquilo que seria gerir ou administrar recursos ambientais para se aproximarem da concepção de simples instrumentos de financiamento de obras e tecnologias que atuam apenas sobre os impactos sofridos por estes recursos. Com a cobrança tendo o caráter de instrumento de arrecadação, ela não cumprirá seu papel no sistema de gestão e não complementará outros instrumentos como a outorga do direito de uso da água.

O cenário anteriormente apresentado também é decorrente de um conjunto de motivos que incentivaram a definição dos temas a serem estudados neste trabalho, quais sejam:

- a escassez dos recursos hídricos;

- a utilização da água, oferta e demanda, a partir da aplicação da cobrança sobre o uso;

- a aplicação da modelagem matemática como instrumento de avaliação da oferta hídrica disponível.

\footnotetext{
*Barraqué, 1995; Kraemer, 1999; Lanna, 2000; Seroa da Motta, 1998; Zabel \& Rees, 1999.
} 


\section{Objetivos}

O presente trabalho busca desenvolver uma metodologia de cobrança pelo uso da água que associe a escassez de recursos hídricos ao valor econômico da água tendo como objetivo primeiro a sustentabilidade do meio e, em sua aplicação, deva permitir flexibilidade e apresentar uma fórmula final simples.

Como objetivos específicos:

- auxiliar no estabelecimento de políticas de conservação e recuperação da qualidade da água, incentivando as ocupações menos impactantes e os usos mais nobres determinados no sistema;

- indicar a relevância das políticas de conservação ambiental no gerenciamento dos recursos hídricos, evidenciando a interface entre os instrumentos de gestão. 


\section{Revisão da Literatura}

Neste acervo teórico são apresentados e analisados fundamentos - conceitos e aspectos jurídico-institucionais pertinentes ao trabalho - que embasam as discussões e os resultados obtidos na aplicação do modelo, bem como as considerações finais.

\subsection{Gestão Ambiental}

O termo gestão pode ser traduzido como administração ou gerenciamento de um conjunto de ações, as quais devem ser fruto de um plano estabelecido a partir de determinados objetivos. Em outras palavras, uma política estabelece metas a serem racionalizadas pelo planejamento cujo resultado, o plano de ação, é executado na gestão. O adjetivo "ambiental" pode acompanhar estes termos, qualificando-os quanto à preocupação em preservar a qualidade do meio ambiente.

Muitas vezes a designação gestão confunde-se com planejamento, principalmente pelas semelhanças entre as possíveis etapas dos métodos existentes. Isto pode ser observado ao se comparar a seqüência de planejamento relacionada por Vieira (1995) com as etapas da gestão ambiental apontadas por Souza (2000):

Como etapas do planejamento apresentam-se:

- identificação de necessidades e objetivos;

- análise de problemas e busca de alternativas;

- implementação e monitoramento de estratégias regionais.

Para a gestão ambiental têm-se:

- caracterização do meio ambiente e da atividade;

- análise de impacto ambiental;

- estratégia para implementação de medidas mitigadoras;

- monitoramento. 
Souza (2000) também coloca a necessidade de uma inter-relação entre as etapas do sistema de gestão ambiental, a fim de existir uma constante atualização do sistema. A dinâmica desse processo é representada conforme figura (3.1):

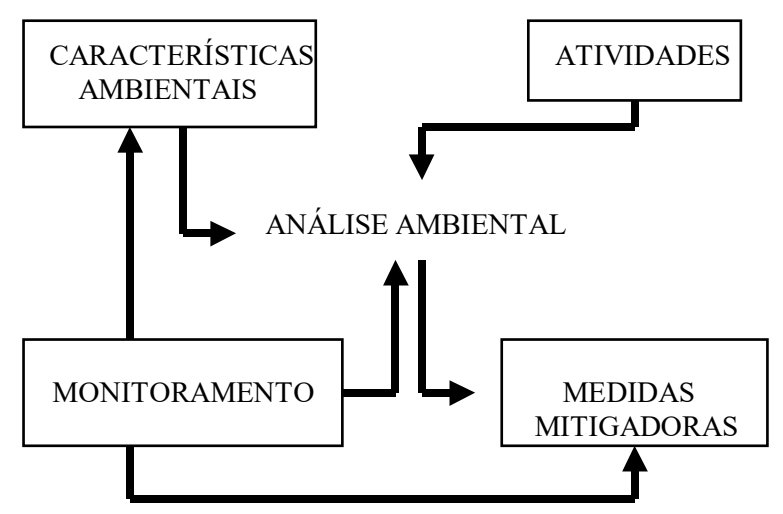

Figura 3.1 - Sistema de gestão ambiental (Fonte: Souza, 2000)

$\mathrm{Na}$ tentativa de explicitar as diferenças entre estes dois processos e de entender como eles se relacionam citam-se Almeida et al (1993), para os quais, modernamente, o processo de planejamento é continuado na gestão, sendo artificial uma separação entre os dois. Em verdade, a gestão é concebida como uma etapa interativa cujos dados realimentam as fases do planejamento, ou seja, o plano, fruto do planejamento, tem a função de coordenar os objetivos para a tomada de decisão e sua conseqüente execução, papel da gestão. A execução é realizada através de programas monitorados, o que possibilita a revisão do plano original.

Também a fim de esclarecer o significado de gestão ambiental e qual seu papel no processo de desenvolvimento, desta vez relacionando-a à política ambiental, apresenta-se a abordagem feita por Moraes (1994), na qual a gestão é considerada atribuição do Poder Público, cabendo a este pôr em prática a Política de Meio Ambiente. Para tanto, deve existir um modelo institucional descentralizado e participativo, no qual os órgãos ambientais estejam articulados entre os programas e ações de produção do espaço, sendo esta articulação função de uma gestão ambiental eficiente. 
Esta eficiência é buscada por Vieira (1995), que mencionando diversos textos de Ignacy Sachs e Olivier Godard*, aponta a necessidade do espaço, recortado para fins de planejamento, ser homogêneo do ponto de vista ecológico e ter uma identidade sociocultural, assegurando uma gestão integrada às potencialidades de recursos existentes. Propõe, para tanto, a utilização piloto de espaços microrregionais como forma de contribuição científica ao trabalho de planejamento, descrevendo-os como sendo "um espaço suficientemente restrito para a efetivação dos diagnósticos participativos e, ao mesmo tempo, em contraste com espaços urbanos ou com as bacias ou microbacias hidrográficas, suficientemente amplo para viabilizar estratégias melhor ajustadas à busca de soluções sinérgicas e complementares entre diferentes atividades produtivas".

No entanto, existe uma tendência atual que atribui à bacia hidrográfica o status de unidade ideal para fins de estudo, planejamento e gestão ambiental. Isto é fácil de compreender quando se consideram apenas os recursos hídricos, visto que existe a visualização do inter-relacionamento dos corpos de água através do escoamento superficial. Além disto, a erosão hídrica, que pode interferir em toda rede de drenagem através do assoreamento, assim como outros problemas da bacia, está intimamente relacionada ao uso do solo, seja pela falta de cobertura protetora do impacto da chuva, seja pela falta de obstáculos necessários ao acúmulo de água a fim de que ocorra o processo de infiltração (Fontes, 1997).

A utilização da bacia hidrográfica como unidade funcional que mais se ajusta à gestão, do ponto de vista ambiental, pode ser preconizada a partir da constatação de que seu comportamento como elemento de características morfológicas peculiares, que o define como eco-sistêmico, facilita a análise e o entendimento dos processos e dos problemas ambientais. Tem-se, inclusive, como exemplo de reconhecimento dos argumentos colocados, a adoção da bacia hidrográfica como unidade de estudo para

* GODARD, O. Aspects institucionnels de la gestion integrée des ressources naturelles et de lénvironnement. Paris, MSH, 1980. ; Ceron, J.P. Planification décentralisée et modes de développement. Paris, MSH, 1985.

$\overline{\mathrm{SACHS}}$, I. et al. Initiation à l'écodéveloppement. Toulouse, Privat, 1981. Ecodesenvolvimento. Crescer sem destruir. São Paulo, Vértice, 1986. Espaços, tempos e estratégias do desenvolvimento. São Paulo, Vértice, 1986. ; Silk, D. Food and energy. Strategies for sustainable development. Tóquio, UNU, 1990. 
o Estudo Prévio de Impacto Ambiental (EIA), a partir da Resolução CONAMA 001/86.

Desta forma, o surgimento de Comitês de Bacias, já consolidados na França, que são ocupados por representantes da sociedade civil e das unidades administrativas constituintes da bacia hidrográfica. Como ressalva, observa-se o fato de as regiões administrativas serem unidades tradicionais de gestão, existindo a tendência dos interesses expressos pelos seus representantes entrarem em conflito com os interesses da gestão compartilhada da bacia. A conseqüência deste conflito é que poucos conseguem pôr em prática a grande quantidade de teorias disponíveis sobre como deve ocorrer a gestão integrada dos fatores físicos, biológicos e antrópicos quando da organização do espaço territorial.

Entretanto, não se pode negar a evolução positiva ao se pensar o planejamento ambiental interativo. Neste, a execução e o controle das ações no sistema de gestão, e mesmo a seqüência de etapas expressa de maneira linear, devem ser modificados por tomadas de decisões baseadas em um fluxo contínuo de informações, existindo um ciclo de retroalimentação do sistema. Esta evolução acompanha outra, a do surgimento de novas diretrizes de desenvolvimento, iniciadas na década de setenta, que culminaram com a definição do que deve ser um desenvolvimento sustentável, conceito que introduziu mudanças significativas no universo dos responsáveis pela implementação de políticas de desenvolvimento, como a forma de abordagem sistêmica do meio e a gestão e o planejamento descentralizados e participativos - condições para que estes possam ser acompanhados do adjetivo ambiental (Delitti, 1995; Vieira, 1995; Souza, 2000).

Talvez, o sinal mais contundente da mudança de postura frente ao meio ambiente seja a incorporação de práticas gerenciais ambientais à operação geral das empresas. A motivação para esta mudança de comportamento adveio inicialmente do cumprimento às regulamentações legais, e ainda hoje este é o motivo principal, já que internalizar os custos sócio-ambientais muitas vezes é visto como uma diminuição do lucro. Todavia, também é sentida a mudança no discurso de representantes ligados à produção industrial, devido ao ganho financeiro que poderia vir da melhor aceitação de seu produto no mercado. Mercado este que, mais do que 
entender a qualidade ambiental como interesse difuso, passa a objetivar seu valor, ao ponto de existirem projetos de inclusão da valoração ambiental no processo de gestão e de definição de políticas ambientais (Motta, 1995).

Posto isso, o que é consenso entre diversos autores, e entre os profissionais da área em geral, é a colocação feita por Godard (1997) de que o futuro do meio ambiente está sendo jogado sobretudo no domínio das modalidades de gestão dos recursos naturais, tanto no caso de os mesmos estarem sendo super-explorados, quanto no caso de sua exploração estar acarretando a degradação do meio ambiente.

Um bom indicativo para soluções deste problema aparece em Sachs (1986), autor que expõe esta preocupação deste o início da década de setenta, colocando a gestão ambiental racional como condição fundamental à prevenção do esgotamento dos recursos naturais e entendendo esta racionalidade como a adoção de um sistema que integre os diversos setores e propicie a atuação das comunidades regionais. Em síntese, modo de agir descentralizado, sistêmico e participativo.

\subsubsection{Gestão de Recursos Hídricos}

Dentre os recursos naturais, a água ocupa lugar de destaque no mundo, seja pela falta deste recurso em diversas regiões seja pelo seu papel essencial à vida e às mais diversas atividades do Homem. A “pouca” quantidade de água doce disponível no planeta também é conseqüência de sua distribuição ser bastante heterogênea, com a relação "habitantes / disponibilidade de água" ficando muitas vezes abaixo do desejável. Como agravante, áreas muito habitadas tendem a esgotar esse recurso, utilizando-o num ritmo acima de sua capacidade de renovação.

Percebe-se que o abastecimento humano e uma variedade de atividades econômicas (agricultura, indústria, navegação, lazer, pesca) dependem dos recursos hídricos em suas mais variadas funções, nas quais desempenham os papéis de insumo, receptor de resíduos, meio de transporte, geração de energia elétrica, suporte para a vida aquática, etc. Essa multiplicidade de usos associada à limitação da quantidade e qualidade dos recursos hídricos disponíveis geram conflitos que somente através de um eficiente sistema de gestão poderão ser administrados e solucionados (Alves, 1997). 
Segundo Souza (1995), equacionar o problema da quantidade e qualidade de água a partir de usos múltiplos necessários ou desejados tem sido um denominador comum aos sistemas de gerenciamento de recursos hídricos. $\mathrm{O}$ autor ressalta que à medida que determinada região se desenvolve e nela se torna mais intenso o uso dos recursos hídricos disponíveis, fica maior o potencial de conflitos entre esses usos e maiores são os riscos de degradação da qualidade dos corpos de água. A implementação de sistemas integrados de gestão de recursos hídricos ocupa uma posição relevante no disciplinamento da apropriação desses recursos e, necessariamente, na manutenção da qualidade dos mesmos. Desta maneira, busca-se uma compatibilização de interesses, muitas vezes opostos (usuário poluidor x usuário consumidor), de maneira que o uso determinado para os recursos hídricos proporcione o máximo de benefícios para a sociedade.

Analisando a situação de recursos hídricos em países em desenvolvimento, Brookshire (1993) listou alguns objetivos a serem alcançados por um sistema de gerenciamento hídrico idealmente concebido:

- realização de investimentos em infra-estrutura de distribuição de água e armazenagem, maximizando os benefícios sociais;

- preços pagos pelos usuários refletindo os custos marginais de oferta de água e descarga de efluentes;

- alocação da água para usos mais valiosos, de maneira que sejam garantidas as necessidades básicas da população em termos de qualidade e quantidade;

- preservação de alguns cursos de água em seus estados naturais;

- desenvolvimento, por parte de alguns agricultores e industriais, de ações para que seus efluentes não comprometam a qualidade dos recursos hídricos;

- incentivo para que o custo marginal de tratamento de efluentes industriais seja igual ao benefício marginal do aumento da qualidade do recurso hídrico para outros usuários.

No Brasil, a Política Nacional de Recursos Hídricos, instituída pela Lei 9.433 de 08 de janeiro de 1997, regulamentou uma série de conceitos, princípios e instrumentos que formam um conjunto de elementos necessários ao gerenciamento dos recursos hídricos. A partir dos princípios instituídos, a água passa a ser considerada um bem econômico, finito e vulnerável; a bacia hidrográfica passa a constituir-se unidade de gestão; impõe-se a necessidade de contemplar os usos múltiplos; e a gestão implementada de maneira descentralizada e participativa. 
Definem-se, ainda, os instrumentos para a efetiva implementação dos sistemas de gestão de águas, a saber: a outorga de direito de uso da água, o Plano Nacional de Recursos Hídricos, a cobrança pelo uso da água, o enquadramento dos corpos de água em classes de uso e o Sistema Nacional de Informações sobre Recursos Hídricos. O uso destes instrumentos de forma harmoniosa reflete o estado da arte no que diz respeito à gestão das águas, facilitando o planejamento e o gerenciamento dos recursos hídricos, compatibilizando interesses difusos e permitindo a preservação da qualidade dos recursos disponíveis - como demonstram algumas experiências internacionais de operacionalização desses instrumentos.

Hubert et al (2002) relatam de que forma estão evoluindo a aplicação dos planos de ordenamento e de gestão dos recursos hídricos na França, destacando como ponto positivo o fato de estes buscarem a utilização eficiente dos dispositivos técnicos, econômicos e jurídicos para a implantação de um desenvolvimento sustentável. Também argumentam que com os princípios contidos nestes planos, espera-se uma maior facilidade na concretização dos objetivos da gestão.

Entretanto, apesar de vasta literatura referente à gestão de recursos hídricos, é preciso que sejam desenvolvidas pesquisas para incorporação de atores e variáveis ambientais locais na implementação dos planos e sistemas de gerenciamento de recursos hídricos já concebidos. Sobre os planos franceses, os mesmos autores citados concluem sobre a dificuldade em transformá-los em ações concretas. A estrutura institucional construída somente poderá ser eficiente caso estejam disponíveis dados locais para subsidiar o processo de tomada de decisão que se pretende participativo. Um sistema de informações é essencial à instrumentalização dos planos de gestão.

No que se refere à implementação de medidas de controle da disponibilidade da água, também observa-se a relevância de se fazer uma interface entre os instrumentos de gestão ambiental, sejam os da Política Nacional de Recursos Hídricos (PNRH) ou os definidos na Política Nacional de Meio Ambiente (PNMA, instituída pela Lei Federal n. ${ }^{\circ}$ 6.938/81). No presente trabalho, existe a referência mais direta à cobrança pelo uso da água e seu papel nessa relação. 
A cobrança compõe os Instrumentos Econômicos de gestão que, de acordo com trabalho da Organização para a Cooperação Econômica e para o Desenvolvimento (Organization for Economic Cooperation and Development OECD, 1991), podem ser definidos como mecanismos que afetam custos e benefícios de alternativas disponíveis aos agentes econômicos, com o efeito de influenciar comportamentos de forma favorável ao meio ambiente.

Estes instrumentos apresentam-se sob as formas de tributos ou taxas ambientais (Environmental charges or taxes), licenças negociáveis (Marketable permits), Mecanismos de depósito (Deposit-refund systems) e Subsídios (Subsidies). Dentre estes, aparecendo mais concretamente no contexto dos recursos hídricos estão os tributos ou taxas ambientais e as licenças de poluição.

Cueva (1991) comenta, em relação à emissão de licenças de poluição, conhecidas como "direito de poluir" ou ainda "certificados de uso ambiental", que as mesmas vêm sendo utilizadas principalmente nos EUA e Alemanha para combater a poluição da água e do ar em áreas industriais. $\mathrm{O}$ autor também coloca que o conceito de licença ambiental cria um mercado artificial com quantidades limitadas de emissão de poluentes, no qual os direitos de poluir são livremente transferíveis dentro destes limites. Para o autor, este instrumento vem sendo aplicado em escalas pequenas e com resultados efetivos questionáveis.

Segundo Mainom (1996), a implantação de licenças negociáveis obedece às seguintes etapas:

- estabelecer o objetivo do nível de poluição desejada ou suportada;

- nível da qualidade ambiental deve ser definido em termos do total de emissões permitidas;

- licenças, que constituem essencialmente direitos de propriedade são alocados às firmas. Cada licença permite ao proprietário emitir uma quantidade específica de poluição;

- as firmas podem negociar estas licenças livremente.

Já os tributos ou taxas ambientais são formas de colocar preços sobre o uso dos recursos ambientais. Para Tietenberg (1994) dois princípios teóricos servem de embasamento à definição destas taxas: o princípio do "poluidor-pagador", 
sistematizado pela $\mathrm{OECD}^{*}$ e mais restrito aos agentes produtivos, e o princípio do “custo-integral”, segundo o qual todos os usuários de recursos ambientais deveriam pagar por todo o seu custo, o que não ocorre, pois é o princípio do poluidor-pagador que rege, na maioria dos países, a definição dos tributos ambientais comumente usados na proteção do ar e dos recursos hídricos.

Cobrar pela água utilizada como fator de produção de bens e serviços e que altera a quantidade ou a qualidade de um corpo de água, como estabelecido na PNRH, também é denominado princípio usuário-pagador, conceito que, segundo Cánepa et al (1999), generaliza o princípio poluidor-pagador ao considerar como semântica adequada a designação usuário para todos os agentes econômicos que utilizam água, inclusive para aquele que polui. Os autores, analisando a aplicação deste princípio frente à $\mathrm{PNRH}$, apontam a tendência de a cobrança ser aplicada baseada no financiamento de intervenções que mantenham a qualidade da água dentro dos limites desejados para seu uso na bacia.

Para a manutenção deste limite de uso da água, dado na PNMA pelo padrão de qualidade, pode-se considerar outro instrumento de gestão, de comando e controle claramente um instrumento pensado para impor limites de utilização da água em função de usos estabelecidos. Segundo Kettelhut et al (1999), por exemplo, a outorga para lançamento de efluentes seria emitida em volume necessário para atingir um mínimo de diluição dos poluentes. Porém, existe um problema quanto ao alcance desse limite: não se pode determinar de maneira cabal que a partir de um instante qualquer, além dos usuários já instalados, ninguém mais poderá usar a água de determinada localidade para algum uso específico. Se o novo usuário potencial propõe se instalar da mesma forma que os usuários já estabelecidos, como ir contra o conceito de bem público atribuído à água? Como negar o direito de acesso à água para iguais?

\footnotetext{
* A OCDE, em 1972, aprovou recomendação sobre aspectos econômicos das políticas ambientais, na qual instituiu o princípio poluidor-pagador (polluter-pays principle) (Kettelhut et al, 1999).

* Emprego de instrumentos das chamadas command and control policies, as quais impõem limites à atuação dos agentes, mediante o estabelecimento de parâmetros, regras ou regulamentos, cuja obediência seria estimulada por penalização ou compensação, conjugados ao monitoramento e polícia ambiental (Lanna, 1998).
} 
Na prática, negar o uso do recurso natural para determinada atividade que apresenta a mesma condição de outra já contemplada com esse mesmo recurso é como restringir este uso somente para alguns, retirando do recurso seu caráter de bem comum. Levada a cabo essa situação, por ter chegado primeiro, o usuário poderia usufruir o recurso natural como se fora seu. Mudar uma condição assim, mesmo considerando a temporalidade de critérios de outorga definidos no sistema de gestão, requer um grande esforço dos envolvidos, além de eficácia também temporária, visto que novo patamar de escassez do recurso deverá ser atingido.

No Brasil, além da outorga, outros instrumentos de comando e controle mais diretamente associados à definição de um limite sustentável para o uso da água são o estabelecimento de padrões de qualidade e de emissão ${ }^{*}$ e o enquadramento dos corpos d'água em classes de uso - os quais a outorga considera explicitamente em sua concepção. Kettelhut et al (1999) aponta esta relação, ponderando que o enquadramento dos corpos d'água em classes de uso será resultado direto dos planos de recursos hídricos, sendo discutido e aprovado, no âmbito da bacia, com a participação dos órgãos de controle ambiental, os quais continuariam exercendo suas atribuições conforme determinações da Resolução CONAMA nº 20/86. Continuando a relação entre estes instrumentos, coloca que deverá ser suspensa a outorga para usuários que não efetuarem o pagamento dos valores fixados pela cobrança.

Também pensando a gestão dos recursos hídricos de maneira integrada, e tendo como referência a sustentabilidade do meio, Souza (1995) propõe um modelo de cobrança associando os valores a serem cobrados aos padrões de qualidade e de emissão. Além disso, o conceito de modelo de cobrança proposto pelo autor visa a possibilitar um melhor diálogo entre esses instrumentos, como demonstrado mais adiante, no "capítulo 4", quando apresentada a metodologia proposta pelo autor.

Um importante passo em direção à sustentabilidade do meio será dado se, além da outorga, a definição dos valores de cobrança considerar um "ponto de saturação" do meio, a partir do qual o recurso água deixará de apresentar a qualidade

\footnotetext{
* Para vários parâmetros, a Resolução CONAMA 20/86 define o limite de concentração permitido no corpo d'água, denominado padrão de qualidade. A mesma resolução define o valor limite permitido em efluentes para as concentrações de vários poluentes, chamado padrão de emissão.
} 
necessária ao uso pretendido. $\mathrm{O}$ caráter complementar entre esses instrumentos é muito importante. As políticas de meio ambiente, e a de recursos hídricos em específico, ao pensarem diversos instrumentos que as colocarão em prática, já consideram esse caráter existente entre eles.

Analisando-se a outorga e o licenciamento ambiental de atividades potencialmente poluidoras que utilizam recurso hídrico como insumo ou como receptor de resíduos, percebe-se que, entre outros direitos, para o usuário lhe é permitido o exercício da atividade se o padrão de emissão for obedecido e se sua atividade de forma isolada não comprometer a qualidade do recurso hídrico dada pelo padrão de qualidade.

Percebe-se, facilmente, a fragilidade da aplicação desses instrumentos no que diz respeito à garantia da sustentabilidade do meio quando se tenta responder a questão que se segue:

- O que acontece quando, mesmo observados os padrões de emissão e de qualidade por todas atividades instaladas em determinada localidade, a soma das alterações provocadas por essas atividades levam o recurso hídrico a uma condição inferior à pretendida para seu uso?

A definição do instrumento de política ambiental deve fundamentar-se na realidade regional e buscar uma melhor alocação dos recursos naturais e um menor custo às atividades econômicas associadas. Logo, medidas devem ser estudadas para a utilização dos instrumentos a fim de que não ocorra o risco de estes comprometerem a eficiência do processo e, principalmente, a qualidade ambiental.

\subsubsection{Cobrança pelo Uso da Água}

O maior interesse na aplicação dos instrumentos econômicos, cobrança inclusa, resulta de três necessidades: mudar a ênfase da política e da prática ambiental recorrendo à prevenção ao invés da correção; recompensar e incentivar 
continuamente as melhorias no campo ambiental; e buscar menores custos efetivos para governos e empresas (Schimidheiny ${ }^{*}$ apud Mainon 1996).

Como os ativos da natureza não têm um proprietário nem um preço estabelecido, os mecanismos de mercado não são capazes de promover uma alocação eficiente dos mesmos. Neste sentido, os instrumentos econômicos devem vir ao encontro da economia de mercado para cobrir a lacuna deixada por esta não ser aplicada apropriadamente aos recursos naturais. Sem a incorporação dos valores sociais e dos preços dos recursos naturais há uma distorção na real composição dos preços finais de uma série de produtos e serviços, na medida em que eles não contemplam as externalidades negativas que ocasionam (Souza, 1995).

Assim sendo, a cobrança pelo uso da água deve figurar em meio aos campos das finanças públicas e das políticas públicas. Enquadrada no primeiro caso, a cobrança gera receitas públicas com finalidades específicas, enquanto os subsídios reduzem o orçamento público em favor de determinadas atitudes a serem incentivadas. No campo das políticas públicas, busca-se uma mudança de comportamento dos agentes. Além disto, a cobrança deve estar em conformidade com o princípio do usuário-pagador, funcionando como um mecanismo de equalização dos custos sociais e privados.

Neste ponto, surge a necessidade da análise da água como bem de caráter público, o que pode ser facilitado destacando-se o primeiro fundamento da atual Política Nacional de Recursos Hídricos: “a água é um bem de domínio público”. Esse fundamento, segundo Machado (2001), implica o comprometimento do Poder Público como gestor da água visando ao interesse de todos. Assim sendo, como a Constituição Federal da República promulgada em 1988 traz grafado que "Todos têm direito ao meio ambiente ecologicamente equilibrado, bem de uso comum do povo...”, chega-se à indicação da cobrança como instrumento de gestão ambiental.

Ainda neste sentido, para Lanna (1998), o Poder Público seria um mediador necessário, responsável por intervir na tensão inevitável entre a racionalidade individual e a ética coletiva, levando à diminuição das tensões próprias da sociedade

\footnotetext{
* SCHMIDHEINY, S. Chainging course: a global perspective on development and the environment. Massachusetts Institute of Technology, 1992.
} 
em relação aos múltiplos usos da água por ela desejados ou necessários. O instrumento econômico de gestão deve assumir um papel imparcial, fazendo com que o uso dos recursos hídricos implique no máximo de benefícios para a sociedade.

Sendo mais específico, e também defendendo a intervenção do poder público a fim de corrigir falhas no sistema de mercado, Garrido (1996) coloca que o modelo de mercado para o gerenciamento ambiental é incapaz de contabilizar os custos sociais que uma decisão individual impinge a todos os usuários dos recursos hídricos e que a cobrança pelo uso da água é a forma de racionalizar a competição entre os usuários e garantir o desenvolvimento integrado das regiões das bacias hidrográficas.

O obstáculo de aplicação dos instrumentos econômicos de política ambiental constitui-se na dificuldade de mensuração dos custos ambientais, ou seja, determinar a valoração ou o valor monetário dos recursos naturais. Entretanto, a cobrança sobre o uso da água já apresenta avanços de implantação em diversos estados brasileiros, sendo uma das metas das políticas estaduais de recursos hídricos.

Em âmbito nacional, observando-se a PNRH, a cobrança deve reconhecer a água como bem econômico, dando uma indicação do seu real valor e objetivando a racionalização de seu uso e dos recursos financeiros obtidos, com o financiamento de programas existentes em planos de recursos hídricos. Ainda no Brasil, a criação da Agência Nacional de Águas (ANA) - Lei 9.984/00 - impulsionou a implementação da cobrança, visto que seu papel é:

- Elaborar estudos técnicos para subsidiar a definição, pelo Conselho Nacional de Recursos Hídricos, dos valores a serem cobrados pelo uso de recursos hídricos de domínio da União;

- Implementar, em articulação com os Comitês de Bacia Hidrográfica, a cobrança pelo uso de recursos hídricos de domínio da União;

- Arrecadar, distribuir e aplicar receitas auferidas por intermédio da cobrança pelo uso de recursos hídricos de domínio da União.

Analisando-se a competência da ANA, vários questionamentos são provocados, dentre eles, a questão da definição dos valores a serem cobrados vem à tona, pois mesmo estando definido o suporte institucional para aplicação dos instrumentos no âmbito da União, ele ainda não está consolidado e, em relação à cobrança, não existe consenso sobre as diretrizes a serem adotadas para definição 
destes valores. Acerca dessa realidade, Garrido (2000) afirma que as propostas para o estabelecimento dos preços são diversificadas e carecem de um direcionamento no que diz respeito aos princípios de cálculo. Para o autor, a uniformidade dos critérios é interessante para que a diversidade dos resultados seja somente devido à especificidade local.

Também é importante frisar que a criação da ANA centralizou procedimentos que caberiam às Agências de Bacias Federais. Esse condicionante não poderá desvirtuar os reais propósitos do estabelecimento da cobrança como instrumento de gestão, ou seja, deverá contar com a participação da sociedade na aplicação do instrumento e evitar que a cobrança seja transformada em mais um tributo para a sociedade brasileira.

Visando à efetiva implementação da cobrança pelo uso da água, entendida como instrumento de gestão dos recursos hídricos e não como mecanismo de arrecadação de recursos financeiros para execução de obras, Barth (1996) lista os seguintes critérios:

- a implementação deve ser universal e deve considerar as peculiaridades das bacias e a capacidade de pagamento dos usuários, utilizando critérios técnicos, econômicos e sociais;

- a implementação deve ser feita gradativamente, iniciando-se onde a disponibilidade de água é crítica;

- a implementação deve considerar a sazonalidade, o tipo e a eficiência do uso da água;

- por fim, devem ser considerados os volumes captados e lançados, sendo que para o efluente também devem ser consideradas suas características biológicas e físico-químicas.

Quando utilizada a cronologia e o conteúdo da legislação brasileira como balizamento de análise acerca desse assunto, também pode ser notado que o caráter meramente financiador está em desacordo com os fundamentos encontrados na origem da cobrança pelo uso da água no Brasil. Pode-se começar observando o antigo Código Civil Brasileiro promulgado em 1916, no qual já constava que o uso comum dos bens públicos pode ser gratuito ou retribuído.

O Código de Águas (Decreto Federal n. ${ }^{\circ}$ 24.643/34) confirmou a possibilidade do uso retribuído da água e acrescentou fundamentos de proteção dos 
recursos hídricos e de proteção da saúde humana, destacando o valor das águas para o desenvolvimento econômico e social. Nota-se que, além da cobrança pelo uso da água, a associação dos usos múltiplos à gestão de recursos hídricos já pôde ser vislumbrada pela primeira vez.

Fornecendo as diretrizes do momento atual, as já citadas Política Nacional de Meio Ambiente e Política Nacional de Recursos Hídricos dão destaque à possibilidade de cobrança pela utilização de recursos hídricos em função do valor econômico associado ao seu uso. Ainda na PNRH, aparecem como fundamentos sobre os quais essa política deve ser baseada, entre outras coisas, a limitação da água como recurso e, por conseqüência, a possibilidade de escassez d'água.

Começa, então, a tomar corpo um maior detalhamento de como devem ser executadas propostas de cobrança e quais devem ser seus objetivos. Entre esses objetivos, novamente destaque-se o reconhecimento da água como bem econômico e, associado a esse reconhecimento, a necessidade de o usuário ter o real valor do recurso hídrico refletido na quantia cobrada.

Percebe-se, mediante as observações até aqui colocadas, que a cobrança é concebida principalmente como instrumento de gestão da escassez de recursos hídricos, ou seja, o caráter econômico da água é dado pelo fato de esta ser um bem escasso e, portanto, possuidor de valor econômico. Assim, não se deve fundamentar o valor cobrado em custos de financiamento de obras e serviços. Mesmo que a cobrança tenha como um de seus objetivos a obtenção de recursos financeiros, e que isto tenha como resultado inicial o aumento da oferta de água, a ênfase da sua formação sempre deverá estar fortemente ligada à sua utilização como instrumento de gestão ambiental.

Retomando as referências legais, a mesma Lei $\mathrm{n}^{\circ}$ 9.433/97 utiliza um princípio segundo o qual o uso da água deve ser pago quando este implica na retirada de determinado volume de água ou no lançamento de poluentes. Significando, em ambos os casos, que os valores cobrados pelo recurso hídrico deverão considerar o impacto ambiental produzido, já que este é conseqüência das características dos usos supracitados (relação causa-efeito). 
Visto que grandes impactos negativos sobre a água podem levar à impossibilidade de seu uso, novamente aparece a necessidade de o valor cobrado junto ao usuário de água ser função da escassez do recurso hídrico. Mais do que isso, o total do valor arrecado pelo sistema de cobrança deve ser fundamentado na gestão dessa escassez, mesmo que o montante arrecadado sirva para o financiamento de ações mitigadoras da oferta de recursos hídricos.

Logo, o sistema de cobrança não deve ter como princípio o rateio de custo para financiar atividades como, por exemplo, abastecimento de água ou de tratamento de esgoto. O produto da cobrança pode financiar esses tipos de serviços, mas as já conhecidas tarifas cobradas pelas companhias de água e esgoto é que devem ser função dos custos desses serviços. Fazendo a distinção entre a cobrança pelo uso da água disponível no ambiente e a cobrança pelos serviços de saneamento urbano, a primeira seria cobrada das companhias tendo como objetivo principal a sustentabilidade ambiental e a segunda continuaria sendo cobrada pelas companhias em função dos custos dos serviços prestados.

Cobrar pela água bruta utilizada, princípio usuário-pagador recepcionado pela PNRH, deve ser feito com algum critério. O desenvolvimento do princípio poluidor-pagador, precursor do usuário-pagador, surgiu a fim de inserir a degradação dos recursos naturais ocasionada pelos agentes econômicos nos custos de suas atividades. No entanto, ele não tem como preocupação original a manutenção de um padrão de qualidade ambiental. Apesar de procurar refletir a escassez do recurso ambiental num aumento de custo, ou de valor desse recurso, esse aumento só estaria "limitado" em função da eficiência econômica do sistema. Assim, se aplicado o princípio citado de acordo com sua concepção original, tem-se apenas a busca da eficiência econômico-financeira, mesmo que também aconteça a associação do valor monetário do recurso ambiental à capacidade de suporte do meio.

A própria $\mathrm{PNRH}$, ao colocar como primeiro objetivo "assegurar à atual e às futuras gerações a necessária disponibilidade de água, em padrões de qualidade adequados aos respectivos usos", e tendo como um de seus instrumentos a cobrança, indica que o valor a ser cobrado pelo uso da água deve buscar, além da racionalização econômica, a sustentabilidade ambiental. 
Finalizando a fundamentação baseada na legislação pertinente à cobrança, justifica-se a utilização dos termos tarifa, preço e taxa a partir de Panone et al (2001), os quais apontam o fato de legislações estaduais de recursos hídricos utilizarem corretamente a expressão "preço público" na qualificação da cobrança. Segundo os autores, o ingresso de recursos financeiros no Tesouro Público deve receber o nome de preço público sempre que o pagamento é efetuado em contraprestação de um serviço ou bem oferecido pelo governo.

Os mesmos autores colocam que a cobrança de recursos hídricos constitui-se em tarifa, não se configurando em imposto ou taxa, posto que estes se tratam de tributos que derivam do patrimônio do particular, o que não se aplica à água. Assim, em função dos fundamentos apresentados até agora, conclui-se que a cobrança pelo uso do bem público água trata-se de tarifa ou preço público.

\subsection{Escassez de Água e Cobrança*}

A discussão sobre a cobrança pelo uso da água, como instrumento de gestão, torna-se cada vez mais relevante devido ao cenário de escassez atual. Entretanto, a maneira com que esse instrumento é aplicado varia entre os países e chega a ocorrer um desvirtuamento do seu principal propósito, que seria o de incentivar os usuários desse recurso natural a usá-lo de forma racional - mediante o estabelecimento da qualidade ambiental desejada - servindo como complemento de políticas de comando e controle quando estas não conseguem, de forma isolada, resolver conflitos.

Os modelos econômicos dominantes na maioria dos países são baseados na corrente econômica neoclássica. Essa base conceitual preconiza que o livre mercado é capaz de maximizar os benefícios sociais e garantir suprimentos ilimitados dos recursos naturais e lugares para dispor os resíduos resultantes dos usos destes recursos.

\footnotetext{
* A base deste item foi apresentada no simpósio da Associação Brasileira de Recursos Hídricos: PESSOA, C. A. P.; FONTES, A. T.; SOUZA, M. P. A cobrança sobre os usos da água: instrumento econômico ou fonte de arrecadação? In: XIV Simpósio Brasileiro de Recursos Hídricos e V Simpósio de Hidráulica e Recursos Hídricos dos Países de Língua Oficial Portuguesa. ABRH, 2001, Aracaju.
} 
Entretanto, inserir a problemática ambiental em um contexto econômico baseado na economia de mercado, no qual o instrumento de regulação é o sistema de preços, tem sido um desafio para os economistas desde o final dos anos 60. O desafio está no fato de que os ativos da natureza não têm um preço e um proprietário definidos, logo, o mercado não tem capacidade de solucionar sozinho os efeitos da escassez relativa dos recursos (Almeida, 1998; Souza, 1995).

Assim, com o objetivo de tratar a questão ambiental no enfoque da teoria econômica neoclássica, adotou-se o conceito de externalidade, entendida como a diferença entre os custos sociais e os privados. O problema é fazer com que os agentes causadores das externalidades considerem os custos sociais de degradação nos seus cálculos privados de custo-benefício, para isso, a intervenção governamental, tão criticada pelos neoclássicos, parece ser necessária e o debate se assenta na escolha dos instrumentos para internalizar as externalidades (Almeida, 1998).

Pigou, em 1920, já chamava atenção para essa diferença que existe entre os custos marginais sociais e os privados. $\mathrm{O}$ autor defendia a existência de uma taxa (Taxa Pigouviana) que corrigisse essa distorção, ou seja, um meio de internalizar as deseconomias causadas pelos agentes econômicos. Sua idéia é, ainda hoje, um marco para aqueles que pretendem trabalhar com instrumentos econômicos.

Partindo das premissas anteriores, a questão é: a que pressupostos os instrumentos econômicos devem atender para que sejam inseridos em uma política de gestão e quais as interfaces deles com os instrumentos de comando e controle. Cabe observar que, os instrumentos econômicos não são considerados uma alternativa aos instrumentos de regulação, mas, sim, um complemento.

Almeida (1998) afirma que no âmbito internacional tem-se privilegiado o uso de instrumentos de regulação direta (comando e controle) devido à sua elevada eficácia ecológica, o que garante amplo apoio da sociedade e influencia a tomada de decisão dos políticos. Porém, apesar de a tendência internacional ser a adoção de instrumentos de comando e controle, verifica-se que é cada vez mais presente a discussão a respeito dos instrumentos econômicos e seu emprego na gestão 
ambiental, por ser uma alternativa economicamente eficiente e ambientalmente eficaz para complementar as políticas de regulação direta.

A cobrança pelo uso da água é um instrumento econômico de gestão de recursos hídricos. No Brasil, sendo o único instrumento detentor de caráter econômico preconizado na Política Nacional de Recursos Hídricos, a cobrança deve ser implementada de forma coerente, induzindo economicamente o agente usuário-poluidor a alterar o seu comportamento em busca da melhoria na qualidade ambiental. Assim, como instrumento de gestão, deve ter como objetivos: racionalizar o uso do recurso natural, considerando sua escassez; reconhecer a água como um bem de valor econômico, internalizando os custos sociais causados pelas externalidades advindas da sua utilização; e ainda, diminuir os conflitos entre os usuários, alocando-os de forma racional, tendo em vista o gerenciamento da demanda e os anseios da sociedade.

Entretanto, segundo Lanna (2000), as políticas de cobrança pelo uso da água estão sendo implementadas no sentido de financiar os investimentos previstos nos planos de bacia a fim de que o valor arrecadado cubra as despesas com obras e serviços que garantam a oferta de água. Para o autor, este objetivo financeiro determinará a tarifa, cuja definição do valor pode ser comparada ao rateio de custo executado para a gestão de um condomínio, papel a ser desempenhado pela bacia hidrográfica.

No mesmo sentido, Seroa da Motta (1998) cita como primeiro objetivo da cobrança o financiamento da gestão dos recursos hídricos, colocando-o a frente da minimização dos impactos ambientais advindos do uso da água. Desta forma, existindo algum consenso sobre as lógicas supracitadas, para que estas não sejam as principais diretrizes da implementação da cobrança no Brasil, é importante dar destaque ao que torna a cobrança um instrumento econômico de gestão dos recursos hídricos.

Observando-se a abordagem conceitual apresentada em Righetto (2001), para efetivamente ser instrumento econômico, a cobrança precisa existir em função da escassez do bem água e, como instrumento de gestão dessa escassez, ela deve visar ao equacionamento dos problemas ambientais advindos dessa escassez, e vice-versa. 
Assim sendo, a cobrança precisa trabalhar com o conceito de sustentabilidade do recurso natural água a fim de minimizar, ou equacionar, os efeitos da escassez d'água.

Essa escassez de água, além de manifestar-se por meio da diminuição de sua quantidade, falta de água propriamente dita, também pode ser reflexo da deterioração da qualidade desejada para determinados usos, condição observada principalmente nas regiões com maior desenvolvimento de atividades econômicas. Em ambos os casos, o desafio é associar o valor cobrado ao grau de comprometimento do uso da água, ou seja, faz-se necessário o diagnóstico do momento em que determinado usuário passe a inviabilizar o uso desejado e, a partir desse instante, fazer com que a cobrança leve os usos a patamares compatíveis com as condições ambientais desejadas.

É importante diferenciar o valor cobrado que é função direta da qualidade da água daquele associado a obras de infra-estrutura, ou ao uso de tecnologia em geral, que visem disponibilizar mais água. Para o segundo caso, fica clara a existência de um limite associado a conflitos de uso da água, já observado em regiões do Estado de São Paulo - conforme estudo da Secretaria Estadual de Meio Ambiente (SMA, 1994), mediante o qual impõe-se um "racionamento". Para o primeiro caso, esse racionamento viria de maneira muito menos traumática, com os usuários tendendo a diminuir a demanda pelo recurso antes de alcançado o limite para seu uso.

Além disso, nada impede que o dinheiro arrecadado com a cobrança aos usuários de água, mesmo não sendo um rateio do custo de obras e serviços de infraestrutura hidráulico-sanitária, seja usado em atividades visando à melhoria da oferta de recurso hídrico. Inclusive, para que os usuários pagadores aceitem a cobrança, é muito importante a utilização do montante arrecadado com a cobrança pelo recurso hídrico, de determinado trecho de corpo d'água, em obras e serviços que visem a sustentabilidade do sistema local.

A partir de toda argumentação acerca dos fatores que devem fundamentar as propostas de fixação de valores para as tarifas a serem cobradas, cabe mais uma vez ressaltar que os preços da água devem obedecer à lógica da cobrança como 
instrumento de gestão ambiental e não outra que a faça ser reconhecida como mera fonte de arrecadação. De maneira mais direta, o preço pago para a utilização da água deve visar ao equilíbrio entre o uso desejado e a disponibilidade de recurso. Isso é ilustrado pela figura (3.2), na qual a cobrança está assentada sobre a escassez de água.

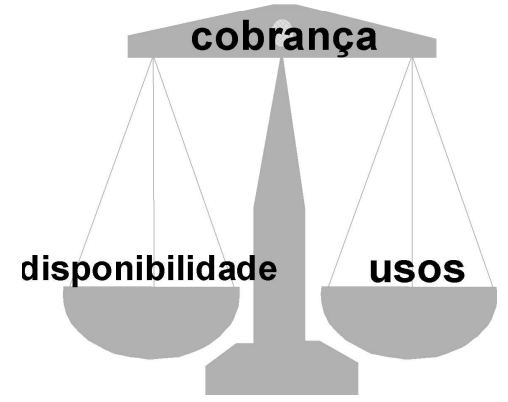

Figura 3.2 - Objetivo da cobrança

A representação do sistema de cobrança por uma balança em equilíbrio sugere o não comprometimento do meio - representado pela disponibilidade de água - em função de seu uso. Nesta linha de raciocínio, esse equilíbrio pode ser entendido como o uso da cobrança baseada na sustentabilidade ambiental, desenhando-se um quadro de relações econômicas constituído pela escassez de água disponível no ambiente, pelos agentes usuários desse recurso e por um instrumento que pretende administrar as alternâncias desse sistema.

A partir dessa lógica exposta, fica claro que atribuir valor monetário a determinado volume de água, escolhido como referência um montante a ser arrecadado, e multiplicar esse valor por coeficientes que reflitam tipo de usuário, sazonalidade, localização etc. não associa de maneira eficiente o valor cobrado ao uso pretendido para a água, apesar de majorar ou diminuir esse valor em função de fatores ambientais.

Cobrar mais quanto menos oferta de recurso hídrico houver garante mais dinheiro para obras de minimização de poluição e de regularização da quantidade, ou pode induzir a menos poluição e a menos captação de água a fim de se pagar menos. Todavia, a carga remanescente dos efluentes e o que restar da quantidade de água consumida, mesmo que "otimizados" em função do valor cobrado, levarão ao comprometimento do uso pretendido para a água mais facilmente se não houver a 
associação da cobrança a um limite para sua utilização. Segundo Souza (1995), a política de gestão dos recursos hídricos não pode basear-se unicamente em atribuição de preços. Faz-se necessária a caracterização das atividades a serem desenvolvidas e o levantamento das potencialidades ambientais, para que a cobrança possa ser concebida sob o prisma da sustentabilidade ambiental.

Isto posto, procura-se no presente trabalho analisar as formas e sistemas de cobrança empregados em alguns países, abordando os respectivos contextos histórico e institucional, bem como, os métodos de cálculo para a definição dos valores a serem cobrados, identificando suas características, reconhecendo seus conceitos e variáveis embutidas, buscando detectar a que finalidade o instrumento procura atender nas diversas experiências abordadas, para então reconhecê-los como instrumento de gestão da escassez de recursos hídricos ou mera fonte de arrecadação.

Primeiramente, cita-se o caso da Inglaterra e do País de Gales, típico exemplo da instrumentalização da cobrança para o financiamento do sistema de gestão dos recursos hídricos. Para estes países, quando analisado documento da agência ambiental responsável pela implantação da política das águas (Environment Agency, 2000), observa-se que o valor pago anualmente sobre captação de água bruta nada mais é do que o custo unitário de administração da bacia cobrado proporcionalmente ao volume outorgado e diminuído ou aumentado em função do tipo de fonte, do período do ano e do tipo de uso.

Ao final do processo, além de dispensada a cobrança para volumes menores que $20 \mathrm{~m}^{3} /$ dia, o valor cobrado junto à parcela de usuários restante subestima o real valor do recurso hídrico. Ao basear-se em custos administrativos, os valores da cobrança são baixos, não induzem ao consumo racional da água e, como conseqüência, têm comprometido a aplicação desse instrumento como verdadeiro instrumento econômico de gestão das águas (Barraqué, 1995; Lanna, 1999; Zabel \& Rees, 1999).

Outros casos de cobrança a serem analisados, com mais detalhamento, referem-se a países que possuem maior tradição no emprego de instrumentos econômicos. Serão analisados as experiências da França e da Alemanha, países que há mais de 20 anos já implementaram a cobrança. A França, em específico, tem 
servido de modelo à formulação das políticas brasileiras de gestão de recursos hídricos.

Como experiência brasileira, será apresentado o caso do Estado do Ceará, pois, apesar de o Estado de São Paulo ter sido o primeiro a possuir uma política de gestão de recursos hídricos, a proposta paulista de cobrança há muito tempo tramita nos gabinetes dos tomadores de decisão, enquanto o caso cearense foi a primeira experiência efetiva de implementação da cobrança pelo uso da água no Brasil.

\subsubsection{O Caso da França}

Na França, como na quase totalidade dos países que se industrializaram e se urbanizaram, os usos de recursos hídricos se diversificaram e trouxeram como conseqüência a eminente degradação das águas. Neste contexto, a cobrança pelo uso da água foi prevista desde a promulgação da lei francesa sobre gestão de água em 1964. Segundo Hubert et al (2002), esta lei tornou-se o marco legal de reestruturação do sistema francês de gestão de recursos hídricos, impulsionada pelos problemas relativos aos conflitos de uso, causados pelo crescente desenvolvimento econômico.

Este marco legal também ocorreu em função da dicotomia “domínio público propriedade privada" existente. Já em 1964, causava conflitos de uso da água o fato de as águas ditas "fechadas" (lagos artificiais), de as águas subterrâneas e de as águas das nascentes captadas em solos privados serem consideradas propriedade dos donos da terra, enquanto, em contrapartida, as águas correntes e seu leito serem públicas, ou seja, serem bens cujo uso é objeto de divisão (Barraqué, 1995).

Assim, o Estado francês, reconhecendo o avanço da escassez dos seus recursos hídricos, passou a impor restrições de uso e, por meio da lei de 1964, criou as Agências de Água e os Comitês de Bacias a fim de efetivar o uso racional da água. A Agência de Água - ou agência financeira de bacia - constitui o executivo dos Comitês de Bacia e tem como funções: aplicar o plano de investimentos; aplicar e arrecadar o produto da cobrança pelo uso da água; efetuar estudos para conhecer a disponibilidade de água e sua qualidade e preparar novas metas de ação para os próximos planos (Barraqué, 1995; Hubert et al, 2002). 
Barraqué (1995) comenta que a criação das agências era necessária devido ao fato de a regulamentação da luta contra a poluição ser insuficiente e mal aplicada e pelo fato de o Estado possuir vocação de apoio ao desenvolvimento econômico em detrimento da qualidade do meio ambiente. Desta forma, sendo os serviços de água considerados bens de caráter industrial e comercial, criou-se a Agência de Água funcionando segundo o princípio poluidor-pagador.

As agências são organismos de resolução de conflitos entre os usuários de água e de financiamento. Para tanto, de acordo com Hubert et al (2002), ela cobra as captações de água e os lançamentos de efluentes sobre uma base incitativa, revertendo o montante arrecadado ao financiamento de obras públicas e privadas de minimização da poluição e à manutenção do sistema de gestão e monitoramento.

Procedendo desta maneira, seu funcionamento é garantido pela cobrança pelo uso da água, que é considerada como um tributo. No entanto, a cobrança é o único tributo importante que não é gerido pelo Ministério das Finanças, o que evita que seja apenas fonte de recursos financeiros para os cofres públicos do Estado francês. Como novo tributo, a cobrança encontrou resistência para sua implantação, tanto dos usuários, quanto do sistema político. Uma estratégia utilizada a fim de quebrar essa resistência foi o estabelecimento da cobrança de forma gradual. Mesmo assim, a cobrança sobre a captação ainda não foi implantada em algumas sub-bacias e parte dos irrigantes não participa do sistema.

O sistema determina que a cobrança seja realizada sobre a captação e o lançamento de efluentes, calculados separadamente, porém, cobrados juntos. Também estão sujeitos à cobrança aqueles que modificam o regime das águas e os que se beneficiam dos serviços ou obras executados com a participação financeira da Agência. $O$ valor para a captação divide-se numa pequena parte para a retirada propriamente dita e, numa grande parte, para a água consumida. O valor estipulado é função de investimentos para atingir metas ambientais. Assim, são diferenciados para cada bacia e muitas vezes não espelham o real valor do recurso, relacionando-se a um rateio de despesas futuras para recuperação do meio (Barraqué, 1995; Seroa da Motta, 1998). 
Segundo Seroa da Motta (1998), os investimentos com a receita gerada são feitos na forma de gastos com gestão, estudos e pesquisas, investimentos de interesse comum e empréstimos aos usuários. Com a receita, os comitês conseguem cobrir $40 \%$ dos investimentos na bacia e os outros $60 \%$ são cobertos por recursos do governo central. Os investimentos são definidos qüinqüenalmente.

Pode-se perceber que na França o principal enfoque da cobrança está na capacidade da geração de receita para investimentos na bacia em que foram geradas, portanto, visa à viabilidade financeira. As cobranças são geralmente aplicadas para qualquer tipo e/ou volume de efluente, até mesmo aqueles dentro dos padrões legais. A ênfase na recuperação de custos, relacionando-os pouco às considerações ambientais específicas, pode ser um primeiro passo, mas não suficiente para dar incentivos à promoção do uso eficiente da água.

Sobre essa eficiência, Barraqué (1999)* admite que os baixos valores cobrados não induziram os usuários de água ao uso racional do recurso preconizado pelo princípio poluidor-pagador. O autor afirma que é o princípio da solidariedade ou mutualidade que norteia a cobrança pelo uso da água na França, pois se trata de um rateio proporcional dos custos de investimentos para a bacia, no qual o valor cobrado pára no ponto que o sistema produz dinheiro suficiente para ajudar os usuários a reduzir seus impactos, de maneira que se atinge um nível médio de qualidade da água que satisfaz a maioria dos usos dos recursos, o que não significa a restauração de um estado próximo ao original.

O mesmo autor afirma, ainda, que se alcançou uma melhoria na qualidade da água por meio de investimentos em tecnologia, e não pelas diminuições do consumo e do lançamento de efluentes. O sistema de gestão da água foi constituído, primeiramente, para lutar contra a poluição devida às descargas pontuais, e esse objetivo foi alcançado com êxito, devido, entre outros fatores, à regulamentação relativa aos rejeitos poluentes e ao auxílio financeiro e à assistência técnica que se pode obter da Agência de Bacia. Porém, ocorreu uma diminuição de águas de melhor qualidade.

\footnotetext{
* Baseando-se em trabalho de Yves Martin: "MARTIN Yves, 1988: "Quelques réflexions sur l'évolution des agences de l'eau", in Annales des Mines, Juillet-Août."
} 
A preocupação agora está voltada para a redução da poluição difusa, incluindo-se aí as descargas urbanas nas enxurradas e a diminuição de substâncias tóxicas e os nutrientes (fosfatos e nitratos) que provêm da agricultura e das estações de tratamento de efluentes. A atenção está voltada ainda para operar e manter os equipamentos existentes e atingir o nível de desenvolvimento sustentável por meio de uma gestão mais integrada.

O dinheiro advindo da cobrança segue um plano de investimentos de melhoria da qualidade ambiental de cada bacia. Os resultados colhidos desta política mostram que houve melhoria na qualidade do recurso hídrico na França, mas a adoção de novos instrumentos e o monitoramento da situação do meio faz-se necessário até como retroalimentação do sistema adotado.

Isso vem sendo alcançado com mais êxito a partir da lei de 1992, na qual a meta ambiental para os recursos hídricos da França ficou mais clara, colocando-se o conjunto da água e dos meios aquáticos no "patrimônio comum da nação" e propondo aos usuários agruparem-se em "comunidades locais da água" com a finalidade de supervisionar a gestão global dos recursos. Os pontos mais importantes contemplados pela nova lei de 1992 são: a modificação do direito da água; a unificação da política da água - efetuada pelo Estado; e a generalização do regime das autorizações de captação e descarga nas águas superficiais e subterrâneas - seja qual for o uso (Barraqué, 1999; Hubert et al, 2002).

\subsubsection{Formação do valor cobrado na França}

A determinação do valor da cobrança é de responsabilidade dos Comitês e das Agências de Água e feito de acordo com estrutura fixada por lei. De acordo com Seroa da Motta (1998), para o cálculo do valor, tem-se:

Cobrança $=Q \times U \times S \times A$

sendo: Cobrança o valor anual a ser pago pelo usuário;

$\mathrm{Q}$ a quantidade de água consumida ou poluição gerada;

U o valor unitário da cobrança;

S o coeficiente setorial;

A o coeficiente ambiental. 
Tem-se, então, o valor cobrado baseado em um valor unitário, modificado por dois coeficientes multiplicadores e proporcional à quantidade de água captada ou poluída. Desta maneira, a princípio, por possuir coeficientes que consideram o tipo de usuário e a qualidade ambiental do meio, a fórmula aponta para a alocação racional e para a observância do preceito da escassez relativa.

Para a captação de água, a escassez já aparece contemplada pelo valor unitário - variável "U” - o qual, segundo Seroa da Motta (1998), varia para águas superficiais e subterrâneas e por zonas de escassez dentro de cada bacia. Essa diferenciação por zonas considera a necessidade de investimentos. Para água subterrânea o valor unitário varia entre US\$ $0,014 / \mathrm{m}^{3}$ e US\$ $0,044 / \mathrm{m}^{3}$, enquanto para água superficial, como a cobrança ocorre apenas em zonas de alta escassez nas épocas de racionamento, pode chegar a mais de US\$ $0,050 / \mathrm{m}^{3}$. Essa característica da cobrança para água superficial também contempla a escassez, além da sazonalidade.

Para o lançamento de efluentes, a variável "U" é diferenciada por poluente e uniforme para toda a bacia, de acordo com a especificidade da bacia, com os objetivos da política e os planos de investimento. Para o cálculo da cobrança de um mesmo usuário que possuí diferentes poluentes considerados na análise da qualidade da água, os parâmetros são agregados de forma aditiva. Os parâmetros empregados são: materiais suspensos; materiais oxidantes; sais solúveis; substâncias inibidoras; nitrogênio reduzido; fósforo; compostos orgânicos alógenos; tóxicos e metais.

O coeficiente setorial "S" é usado para diferenciar o usuário. De acordo com Seroa da Motta (1998), o coeficiente de consumo urbano normalmente é superior ao industrial, existindo para a poluição urbana um coeficiente de aglomeração que varia de 0,5 para pequenas comunidades a 1,4 para grandes áreas urbanas. É interessante notar que este coeficiente multiplicador, no caso das pequenas áreas urbanas, funciona como "subsídio social" ao valor unitário, o qual poderia se imaginar como sendo o valor referência mínimo a ser cobrado.

Ainda sobre os tipos de usuários, Martinez Jr. (1997) observa que as Agências das Bacias Adour-Garonne e Loire-Bretagne cobram dos usuários da água que a utilizam para a geração de energia elétrica, por modificar o regime das águas. O valor é calculado com base no volume anual de água turbinado e no desnível 
introduzido pelas barragens. Esse dado torna-se interessante frente às argumentações existentes, inclusive no Brasil, que consideram a água para a geração de energia um uso não consuntivo e, portanto, isenta de cobrança.

Por último, temos o coeficiente ambiental "A", usado para diferenciar o meio receptor na diluição de poluentes quando do lançamento de efluentes e podendo variar de 1,4 - para corpos com bom padrão de qualidade - a 1,0 - para corpos com padrão de qualidade mais comprometido. No caso de captação, a variável "U" já considera a qualidade do corpo receptor, sendo os valores cobrados mais altos para captações em trechos de montante, onde as águas costumam ser menos poluídas. Dessa forma, o coeficiente "A" não compõe o valor cobrado para captação (Lanna, 1999; Seroa da Motta, 1998).

É interessante perceber que o coeficiente ambiental é empregado tendo maior incidência sobre usuários que utilizam corpos d'água com qualidade ambiental melhor. Desta forma, fica evidenciado um contra-senso, pois a cobrança deve refletir a escassez relativa, ou seja, águas com poder de depuração maior (boa qualidade ambiental) devem ser taxadas de forma módica em relação a corpos de baixa qualidade, para incentivar os usuários a localizarem-se em meios não saturados, respeitando o padrão de qualidade, que por sua vez deverá refletir uma situação ecológica sustentável.

O mesmo contra-senso observa-se para o caso da variável "U" quando da cobrança sobre captação. Ao determinar valores maiores para zonas da bacia onde a água apresenta maior qualidade, a cobrança, na prática, pode corresponder a um incentivo para instalação de atividades onde o recurso natural já se encontra escasso, diminuindo seu poder de assimilação em função de uma maior quantidade retirada.

Chapuy $^{*}$ apud Seroa da Motta (1998), analisando os resultados da implementação desta forma de cobrança na França, verificou que os investimentos elevaram a taxa de tratamento de efluentes domésticos de cerca de 50\% em 1982 para mais de $72 \%$ em 1992. Simultaneamente, a indústria reduziu as emissões de carga orgânica em cerca de 27 \% e de sólidos suspensos e material tóxico em 38 \%.

\footnotetext{
* CHAPUY, P. Evaluation de l'efficacite et le l'éfficience des systemmes de redevance de polltion de l'eau: etude de cas da la France, direction de l'environment. OECD, 1996. mimeo.
} 
No entanto, como já mencionado anteriormente neste item, a melhoria veio muito em razão de investimentos tecnológicos e pouco em função do valor ambiental assumido pelos usuários do sistema.

Possível explicação para essa realidade está no fato de o sistema de cobrança empregado na França, apesar de trazer embutidos critérios que levam em conta a escassez relativa dos recursos, a racionalização do uso e a melhor alocação dos usuários - tais como: tipo de usuário, localização, sazonalidade, capacidade de assimilação (aplicada de maneira equivocada) e tipo de efluente - ter como finalidade última cobrir custos financeiros de infra-estrutura na bacia hidrográfica ao invés de apresentar valores incitativos de um comportamento mais racional em relação à utilização dos recursos naturais.

Sintetizando, o sistema francês de cobrança tem por base o rateio de custos de investimento, portanto, visa a viabilidade financeira. Contudo, a metodologia francesa traz embutida a observância da escassez do recurso, apesar de pecar ao permitir que valores maiores sejam cobrados sobre lançamentos em um meio receptor com capacidade de assimilação maior, justamente onde deveria ser restringida a ocupação devido à escassez do recurso. Desta forma, por não atingir o objetivo da alocação eficiente dos usuários na bacia, o sistema de cobrança na França não pode ser considerado um instrumento econômico.

\subsubsection{O Caso da Alemanha}

Analisando-se a política ambiental alemã (Federal Ministry for the Environment, Nature Conservation and Safety, 1998), observa-se que a gestão dos recursos hídricos na Alemanha é caracterizada pelo federalismo, feita principalmente no âmbito dos Estados (Länder), diferentemente da França, que possui como unidade gerencial as bacias hidrográficas* . De forma concorrente, o poder e a capacidade administrativa se estendem também aos municípios, por meio da autonomia municipal, o que garante uma gestão descentralizada e integrada do solo e da água.

\footnotetext{
* A única exceção, na Alemanha, é a bacia do rio Ruhr.
} 
Este sistema de gestão de recursos hídricos foi instituído pela Lei Federal de Recursos Hídricos de 1957, definindo que a competência legislativa, que era limitada aos Estados, passasse a ser também da Federação, cabendo aos Estados completar e reforçar, mas não atenuar a legislação federal (Barraqué, 1995; Seroa da Motta, 1998).

Apesar de a competência legislativa ser concorrente, cabe apenas aos Estados a implementação das políticas de proteção e gestão das águas. O poder de polícia também é competência dos Estados, porém, é dividido em diferentes níveis de administração, chegando aos municípios. Sobre a competência interna aos Estados, estes têm estruturas institucionais diferentes, a maior parte possui um Ministério do Ambiente responsável pela reconquista da qualidade das águas, enquanto outros confiaram o ambiente ao Ministério da Agricultura, partindo do conceito de proteção da natureza. Cabe observar que nas Cidades-Estado de Berlim, Bremem e Hamburgo a estrutura administrativa da água é diferente e mais simples que as demais (Federal Ministry for the Environment, Nature Conservation and Safety, 1998).

Independente da estrutura administrativa diferenciada por Estados, com relação ao domínio das águas, em toda a Alemanha tanto as águas superficiais quanto as subterrâneas são consideradas bens comuns e só são apropriáveis até o ponto que não lese os vizinhos ou outros habitantes ribeirinhos. Desta forma, todos os usos da água necessitam de uma licença, a qual é considerada o instrumento primário de gestão das águas. Essa licença estabelece o direito a um uso de água específico onde os efeitos no corpo d'água são bem conhecidos, e a sua recusa segue objetivos de qualidade da água (Kraemer, 1999).

A respeito das licenças, Barraqué (1995) comenta que em 1957, a autorização era concedida no quadro de uma abordagem por captação, ou seja, a retirada não poderia comprometer a qualidade da água desejada para o recurso hídrico (padrão de qualidade), no entanto, permitia descargas em águas já fortemente poluídas. $\mathrm{O}$ autor afirma que, somente em 1976, a abordagem por lançamento foi introduzida, quando a preocupação voltou-se para o estabelecimento de padrões de emissão, porém, deixando a preocupação com a situação ecológica do corpo hídrico para segundo plano, dando prioridade ao princípio poluidor-pagador. 
Percebe-se que, somente em 1976, houve uma preocupação mais forte com o estado das águas já comprometidas pelos lançamentos de efluentes. Assim, surgiu a discussão acerca da cobrança pelo uso da água, a qual veio reforçar a intervenção federal nas políticas de recursos hídricos, sendo definida, segundo Seroa da Motta (1998), na forma de uma taxa federal, a ser administrada pelos Estados e aplicada sobre o lançamento de efluentes de usuários urbanos e industriais.

Atualmente, a cobrança é largamente empregada na Alemanha, tanto na esfera federal quanto na estadual e municipal. Ela é efetuada sobre a captação e sobre o lançamento de efluentes e possui diferentes valores entre as unidades administrativas. Sua adoção serviu para reduzir o "déficit de implementação" de políticas ambientais que usavam somente instrumentos de regulação direta. Desta maneira, o instrumento econômico passou a funcionar conjuntamente com o sistema de licenças e a arrecadação é utilizada na melhoria da qualidade da água (Kraemer, 1999).

\subsubsection{Formação do valor cobrado na Alemanha}

A cobrança pela captação é efetuada em diversas regiões da Alemanha, como as de Berlim, Hamburg e Hessen, e é baseada no volume, no tipo de fonte (superficial ou subterrânea) e no uso final do recurso (irrigação, abastecimento público, etc). Retiradas menores que $2000 \mathrm{~m}^{3}$ /ano são isentas de cobrança (Lanna, 1999). Excetuando-se o tipo de fonte, o sistema usado para cobrança pela captação carece de fatores que considerem a escassez do recurso, pois os critérios parecem ser uniformes para todas as regiões e não levam em conta a sazonalidade nem as especificidades locais. A justificativa para esse fato parece estar na licença que é dada aos usos específicos e que, como já mencionado, levam em consideração os objetivos de qualidade da água.

Geralmente, valores mais altos são aplicados sobre a água subterrânea, especialmente para usos que não sejam o de abastecimento público. Os Estados de Hamburg e Hessen, por exemplo, só cobram por captações subterrâneas. Algumas conseqüências do nível incitativo do valor cobrado para captação foram: a devolução, por parte dos usuários, do direito de uso da água subterrânea, fato 
ocorrido em Hamburg; o decréscimo de uso pelas indústrias, que passaram a reciclar a água nos processos; e o uso mais eficiente por parte dos usuários domésticos e pequenos comércios (Kraemer, 1999; Zabel et al, 1999).

O fato de a água subterrânea possuir um valor mais alto de cobrança é coerente com o princípio de escassez relativa, já que incentiva o uso da água superficial, recurso que possui capacidade de renovação maior. Ele também contempla a racionalização do uso da água, ao resguardar um recurso de alta qualidade para usos mais nobres, como por exemplo, o abastecimento público.

Relativo aos recursos arrecadados pela cobrança sobre captação, eles são utilizados, muitas vezes, para compensar os agricultores pelas restrições das zonas de proteção e para subvencionar os usuários que economizam água. Além disso, no Estado de Baden-Württemberg, por exemplo, os recursos são usados para compensar agricultores pelo efeito da redução do uso de fertilizantes e pela aplicação de agrotóxicos mais caros, porém menos agressivos ao ambiente, o que protege usos como a captação para abastecimento. Apesar desse tipo de subsídio trabalhar no sentido oposto ao princípio poluidor-pagador, se for adequadamente aplicado pode ser mais barato (custo-efetividade) do que o incremento no tratamento de água (Kraemer, 1999; Zabel et al, 1999).

Interessante observar que as compensações aos proprietários de terra pela manutenção das matas ciliares refletem a integração do sistema de gestão, relacionando a gestão da água com a do uso do solo. Também cabe destacar a utilização de recursos arrecadados com a cobrança na manutenção de um sistema de bonificação para aqueles usuários que conseguem uma maior eficiência na utilização do recurso natural e de tecnologias limpas, ou seja, tecnologias ambientalmente mais adequadas.

A cobrança pelo lançamento de efluentes está atrelada ao sistema de licenças que, para esse caso, estabelece o padrão de emissão para usos industriais específicos, partindo da premissa de utilização da "melhor tecnologia disponível", ou seja, o padrão de emissão é baseado na eficiência do melhor sistema de tratamento possível para determinado poluente. Quando esses padrões de emissão são atingidos, os 
valores cobrados são reduzidos em $75 \%$, incorporando grande incentivo à redução das concentrações (Zabel et al, 1999).

O sistema alemão de cobrança sobre o lançamento de efluentes considera $o$ volume e a concentração do poluente. Cada tipo de poluente possui sua respectiva unidade de poluição e a cobrança é feita sobre a quantidade de unidades de poluição contida no efluente. Alguns exemplos das unidades de poluição são, de acordo com Federal Ministry for the Environment, Nature Conservation and Safety (1998), $50 \mathrm{~kg}$ de oxigênio (para o caso da DBO); $3 \mathrm{~kg}$ de fósforo; $25 \mathrm{~kg}$ de nitrogênio; $1 \mathrm{~kg}$ de cobre; etc. O preço pago pela unidade de poluição tem aumentado ao longo dos anos: em 1981 era de US\$ 6,7; em 1993 de US\$ 33,7; e em 1997 chegou a US\$ 39,3 (Lanna, 1999; Seroa da Motta, 1998).

Observando-se os critérios adotados para a cobrança sobre o lançamento de efluentes, chama a atenção o fato de que o sistema proposto não leva em conta, em nenhum momento, a capacidade de assimilação do corpo receptor, ou seja, a escassez do recurso. Por ser adotado de maneira uniforme para toda a federação, não observando as especificidades locais, esse instrumento não pode ser considerado de gestão, pois negligencia o padrão de qualidade do meio, requisito crucial para o estabelecimento da sustentabilidade.

O produto da cobrança pelo lançamento de efluentes tem sido empregado na melhoria da qualidade da água. Em torno de $20 \%$ da arrecadação são gastos na administração do sistema e o restante é utilizado pelos estados para o financiamento de investimentos municipais em água e esgoto. Embora a cobrança possua um determinado caráter incitativo, sua função de financiamento se sobressai e seu papel regulador é reduzido (Kraemer, 1999; Seroa da Motta, 1998).

Apesar de a função de financiamento ser mais notória, as autoridades alemãs, consideram a cobrança pela poluição como um incentivo maior para redução da poluição pontual do que as abordagens comando e controle, como as licenças de lançamentos. Este sucesso deve ser creditado aos altos valores cobrados, que têm sido incrementados sistematicamente ao longo do tempo (Kraemer, 1999).

Tem-se, portanto, o caráter de arrecadação da cobrança suplantando o de racionalização do uso, mesmo que esta venha sendo alcançada devido aos altos 
valores cobrados. Como a formação do preço baseia-se em premissas descoladas da qualidade ambiental desejada, no futuro, esses valores, apesar de serem aumentados sistematicamente, podem estar defasados daqueles que refletiriam o real valor do recurso hídrico.

Por fim, deve-se pensar o sistema alemão de cobrança sempre atrelado ao sistema de licenciamento pelo uso da água. Para o caso de captação, por exemplo, a estipulação dos valores é uniforme para todas as regiões e, conseqüentemente, não considera a escassez da água. No entanto, essa falha pode ser compensada, em parte, pelo fato da outorga da licença levar em conta a possibilidade de comprometimento da qualidade do corpo d'água, cabendo à atuação da licença, e não da cobrança, a garantia de uma situação ecológica aceitável. Para o caso da cobrança sobre o lançamento de efluentes, a cobrança é efetuada sobre qualquer quantidade lançada, porém, aqueles que obedecem ao padrão de emissão têm desconto no valor cobrado.

Note que a observância somente do padrão de emissão não garante a observância do padrão de qualidade do corpo receptor. Pelo contrário, mesmo que o bônus àqueles que emitem dentro das normas incentive a diminuição da concentração dos poluentes no efluente, também pode incentivar os mesmos a lançarem um volume maior do que o fariam sem esse desconto, pois o dinheiro economizado passaria a ser empregado no pagamento da cobrança sobre captação. Assim, o aumento da carga poluidora comprometeria ainda mais o corpo receptor e os objetivos de qualidade não seriam alcançados.

\subsubsection{Experiência Brasileira: o caso do Ceará}

A partir da década de 80, substituindo papel até então desempenhado pelo Departamento Nacional de Obras Contra Seca (DNOCS), o Estado do Ceará começou a atuar de forma relevante em políticas de gestão das águas e, dessa forma, conduziu a realização do Plano Estadual de Recursos Hídricos, que foi o passo inicial para a política de águas no Ceará. Neste plano foi previsto um arranjo institucional do sistema de gestão, e dele foi gerada a Política Estadual dos Recursos Hídricos (Lei Estadual $n^{0} 11.996$ de 1992), que já previa a cobrança pelo uso da água bruta, e a própria Política Tarifária, implantada no ano de 1996. 
Segundo a Secretaria dos Recursos Hídricos do Estado do Ceará - SRH (2001), em novembro de 1996 foi promulgado um decreto estadual estabelecendo os valores das tarifas das águas dominiais do Estado, bem como os usos sujeitos à cobrança: usos industriais e de abastecimento de água potável. Não foi contemplada, nesta ocasião, a cobrança sobre a irrigação, a qual foi estabelecida em meados de 1997.

A competência administrativa para aplicação da cobrança pelo uso da água é da Companhia de Gestão de Recursos Hídricos - COGERH, criada em 1993. É dela, também, o suporte institucional sobre todo e qualquer fornecimento de água bruta advindo dos mananciais superficiais e subterrâneos que integrem o sistema de oferta dos recursos hídricos do Estado. Porém, de acordo com a SRH (2001), a COGERH, atual executora da política de cobrança e responsável pelo monitoramento do sistema, não seria a responsável pela arrecadação dos montantes cobrados. Originalmente, a Lei 11.996/92 definia que a tarifa arrecadada em nome do Sistema Integrado de Gestão dos Recursos Hídricos deveria ser depositada no Fundo Estadual de Recursos Hídricos.

No plano operacional, o Ceará adota a bacia hidrográfica como unidade de planejamento. O amadurecimento da unidade de gestão e a participação efetiva da sociedade, por meio das comissões de usuários de água, têm levado à formação dos respectivos Comitês de Bacia. Nesse tocante, a COGERH, com suas superintendências de bacias, atua como uma agência central de bacias para todos os usuários de água do Estado.

Esta estrutura centralizada difere de outros modelos institucionais adotados em outros estados brasileiros e na França. Além disso, ela é contrária àquilo que se deve observar numa gestão ambiental que obedeça aos preceitos da sustentabilidade, mais especificamente, quando devem ser consideradas as especificidades locais. No entanto, ela é defendida por Asad et al (1999), segundo os quais, a estrutura descentralizada provou ser ineficiente ao se considerar a capacidade institucional do Ceará, a fragilidade dos sistemas de recursos hídricos frente a uma escassez severa e a confiança num sistema integrado de reservatórios. 
Sobre a metodologia de alocação da água praticada no Estado, Araújo e Souza (1999) afirmam que esta pressupõe a organização dos usuários (seja na forma de comitê, seja na forma de comissão) e o apoio técnico do órgão gestor - COGERH. O que já é observado de alguma forma, já que a cada ano, no início do período de estiagem, são realizados seminários para cada bacia e/ou vale visando à definição da vazão a ser liberada de cada reservatório, da regulamentação dos volumes outorgados entre usuários por meio de um processo de negociação e de medidas de controle de quantidade e qualidade da água.

\subsubsection{Formação do valor cobrado no Ceará}

Em 1996, o governo do Estado, por meio do Decreto $\mathrm{n}^{\mathrm{o}}$ 24.264/96, estabeleceu as tarifas a serem cobradas pela COGERH para usos e usuários industriais e concessionários de serviços de abastecimento, em águas superficiais e subterrâneas de domínio do Estado, observada a emissão de outorga a ser efetivada pela Secretaria dos Recursos Hídricos do Estado. Em dezembro de 1997, preservando o estabelecido em 1996, definiram-se os critérios que orientam a atual política global da tarifa de água bruta estadual:

- Uso Industrial - 50\% do valor da água tratada fornecida pela Companhia de Água e Esgoto do Ceará (CAGECE) para o uso industrial com consumo superior a $70 \mathrm{~m}^{3} /$ mês.

- Concessionárias de abastecimento de água potável - 1/60 (um sessenta avos) da tarifa para os usos e usuários industriais de água bruta.

- Uso com irrigação, piscicultura e aqüicultura (utilização do espelho d'água) - A tarifa será discutida e acordada nos Comitês e Comissões de Usuários.

- Usuários de água pressurizada ou conduzida em canais - as tarifas serão fixadas para cada sistema através de portaria do Secretário de Recursos Hídricos.

A tarifa fixada para as indústrias correspondeu a $\mathrm{R} \$ 0,60 / \mathrm{m}^{3}$, enquanto para as concessionárias de abastecimento, a tarifa fixada foi de $\mathrm{R} \$ 0,01 / \mathrm{m}^{3}$. Acerca destes valores, Lanna (1999) comenta:

“Aparentemente estes valores foram arbitrados mais em função de negociações com os usuários do que em função de outras referências econômicas ou financeiras. Essa cobrança, no entanto, não pode ser considerada pela retirada de água bruta, pois, no semi-árido, a água 
só pode ser disponibilizada pela implantação de reservatórios - sendo assim, a COGERH estaria cobrando a água como contrapartida pelo serviço de sua disponibilização a partir dos reservatórios que opera e dos que planeja construir".

Como se percebe, a implantação da cobrança no Ceará não pode ser considerada como a de um instrumento de gestão. Deu-se tão somente uma forma de arrecadação de recursos, os quais, por vezes, não são aplicados em investimentos, mas sim na administração do sistema e em operação e manutenção da infra-estrutura existente. Os valores adotados foram desprovidos de qualquer referência ambiental, tendo por base somente o custo da água tratada pela CAGECE. Esse fato é preocupante, pois o Ceará possui uma escassez severa de água, e a cobrança, não somente a outorga, poderia contribuir para a alocação e o uso racional da água.

Retomando-se os critérios que orientam a atual política global da tarifa de água bruta estadual, para as tarifas a serem acordadas nos comitês e nas comissões, entre elas a tarifa para a irrigação, as negociações com usuários na definição dos valores, às quais se refere Lanna (1999), são complexas, existindo apenas algumas experiências preliminares à efetiva implantação. Entretanto, apesar de a tarifa para a irrigação ainda não ter sido implementada, existem estudos de cobrança sobre este uso, caso de Araújo (1996), o qual, a partir de estudo realizado por Lanna ${ }^{*}$, propõe um modelo de cobrança pelo uso da água para irrigação baseado no custo médio da água bruta da bacia, englobando a recuperação financeira dos investimentos em infra-estrutura e considerando um período de retorno de 50 anos e juros de $8 \%$ ao ano.

O modelo contempla uma forma de subsídio cruzado, a área irrigável e o volume de água utilizado. No modelo existe a possibilidade de escolha, por parte do tomador de decisão, da área limite que levaria o usuário ter o subsídio, ou a sobretarifação. Aqui, o modelo utiliza princípio semelhante ao da França para a captação de água por pequenas comunidades. Para melhor ilustração, a seguir, é apresentada a expressão que representa o modelo:

\footnotetext{
* LANNA, A.E.L. Estudos para Cobrança pelo Uso de Água Bruta no Estado do Ceará. Fortaleza: COGERH, 1995. (Relatórios técnicos COGERH)
} 
Tarifa $=S 1 . A+\$ a . V$

sendo: S1 o subsídio;

A área irrigável;

\$a o custo médio da água bruta da bacia;

$\mathrm{V}$ o volume utilizado.

A aplicação do modelo foi feita para a bacia do Rio Curu e os resultados mostraram que ele "pune" propriedades improdutivas, por meio de altos custos unitários. Propriedades com altas taxas de uso da terra teriam custo médio próximo à média da bacia. Cabe destacar que apesar de a cobrança sobre irrigação não ter sido implementada, existe por parte dos agricultores uma relevante disposição a pagar pela água, desde que a oferta hídrica seja garantida durante todo o ano.

Ainda sobre o modelo proposto por Araújo, Garrido (2000) comenta que a sua utilização poderá causar distorções na alocação da água entre os irrigantes e incentivar seu consumo excessivo, pois estimularia os agricultores a utilizarem todas as suas terras irrigáveis, mesmo não havendo viabilidade para tal uso. Entendida esta viabilidade como ambiental, isso não seria verdadeiro. $O$ fato de o cálculo ser baseado em terras classificadas como irrigáveis, imaginando critérios adequados para esta classificação, já garante essa viabilidade e, além disso, utiliza a cobrança para integrar a gestão dos recursos água e solo.

Por outro lado, entendida esta viabilidade como econômica, de fato isso poderá ocorrer, pois o valor cobrado onera, por demais, propriedades improdutivas, que passariam a ter que irrigar para diminuir seu custo unitário com água. No entanto, a improdutividade pode estar relacionada com a falta de mercado para os produtos ou, como já alertado pelo autor dessa proposta de cobrança, pela não disponibilidade de água suficiente para atingir toda área irrigável. Essa segunda hipótese levaria a uma grande contradição, na qual o sistema puniria o usuário por existir deficiência do próprio sistema.

O modelo proposto por Araújo (1996) contempla a necessidade da gestão integrada entre o solo e a água, porém, como o próprio autor afirma, é preciso alguns ajustes para aplicá-lo, como, por exemplo: considerar a sazonalidade na estimativa do consumo de água para irrigação; avaliar os custos da água baseados em 
investimentos futuros, custos de operação, manutenção e gerenciamento; considerar a capacidade de pagamento das populações atingidas pela cobrança.

Atualmente, novos estudos de política tarifária estão sendo executados. Para o caso de usos de água ditos não consultivos, SRH (2001) propõe uma tarifa "educativa" para a pesca, considerando a baixa capacidade de pagamento do setor, e uma tarifa de cunho "prospectivo" para a geração de energia. O mesmo estudo, considerando a capacidade de pagamento dos setores de abastecimento humano, irrigação, indústrias e dessedentação de animais, propõe como tarifa um rateio de custos de operação e manutenção, de infra-estrutura e de compensações advindas de possíveis transposições entre bacias.

No estudo supracitado, a fórmula do rateio é dada calculando-se, como primeiro passo, a arrecadação anual $\left(\mathrm{Z}_{\mathrm{U}}\right)$ conforme expressão (3.3):

$$
Z_{U}=x_{1} \cdot C_{I}+x_{2} \cdot C_{O \& M}+Z_{C}-Z_{P}
$$

sendo: $\mathrm{x}_{\mathrm{i}}$ os fatores entre zero e um;

$\mathrm{C}_{\mathrm{I}}$ os custos de investimentos;

$\mathrm{C}_{\mathrm{O} \& \mathrm{M}}$ os custos de operação e manutenção;

$\mathrm{Z}_{\mathrm{C}}$ os valores das compensações;

$\mathrm{Z}_{\mathrm{P}}$ os valores arrecadados aos poluidores.

Para a determinação da arrecadação anual referente a um determinado uso $\left(\mathrm{Z}_{\mathrm{U}, \mathrm{i}}\right)$, basta multiplicar " $\mathrm{Z}_{\mathrm{U}}$ " pelo fator de rateio correspondente ao uso, sendo que a soma dos fatores de todos os usos deve ser igual à unidade. Em seguida, calcula-se o custo médio $\left(\mathrm{C}_{\mathrm{M}}\right)$ dividindo-se " $\mathrm{Z}_{\mathrm{U}, \mathrm{i}}$ " pela vazão total destinada ao uso. Por fim, a SRH (2001) aponta, como modelo próprio a definição do valor da tarifa cobrada junto ao usuário $\left(\mathrm{T}_{\mathrm{U}}\right)$, modelo com subsídios cruzados também elaborado por Lanna e modificado por Araújo (1996). O modelo considera os custos médios da água aplicado a quantidade de recursos hídricos utilizada e está representado pela expressão (3.4):

$$
T_{U}=Q_{U} \cdot C_{M}+\left(1-e^{-N_{1} \cdot Q_{U} 2}\right) \cdot N_{2} \cdot Q_{U}-N_{3}
$$

sendo: $\mathrm{Q}_{U}$ a vazão retirada do sistema pelo usuário;

$\mathrm{C}_{\mathrm{M}}$ o custo médio da água;

$\mathrm{N}_{1}, \mathrm{~N}_{2}$ e $\mathrm{N}_{3}$ os parâmetros do sistema. 
Também existem estudos acerca da cobrança sobre o lançamento de efluentes, apesar de esta ainda não existir no Estado. A SRH (2001) sugere a adoção de metodologia de cobrança desenvolvida em Souza $(1995)^{*}$ como base ao cálculo dos valores arrecadados junto aos poluidores $\left(Z_{P}\right.$ da expressão 3.2), com ressalvas sobre a necessidade em se definir o montante para financiamento de ações na área ambiental e qual parcela desse total arrecadado será reservada ao sistema de gestão. Entretanto, na prática, essas "ressalvas" invertem o princípio da metodologia base, tornando-a mera fornecedora de multiplicadores aos valores do custo rateado.

Em vista do exposto sobre a atual política de cobrança cearense e sobre os estudos de implementação de nova política tarifária, observa-se a utilização da cobrança sobre o uso da água como instrumento de financiamento de obras e serviços. No entanto, por possuir uma grande escassez de água, o Estado deveria utilizar a cobrança como forma de garantir o acesso à água em quantidade e qualidade e não como fonte de arrecadação. É notória a necessidade de conciliar a gestão do uso do solo com gestão da água, e no caso do Ceará isso se agrava, pois nem sempre onde existe solo existe água e vice-versa, assim, a fórmula de cobrança poderia ajudar no alcance deste objetivo.

Concluindo, percebe-se que os três casos abordados - França, Alemanha e Ceará - possuem grandes disparidades, tanto no que diz respeito às características ambientais, como às institucionais. Os sistemas de cobrança empregados nos três casos são diferentes e os resultados de sua implementação também. No entanto, em todos eles, infelizmente, a preocupação com a qualidade ambiental não é o foco principal, o qual encontra-se no valor arrecadado para investimentos.

Ao final do processo, a aplicação dos sistemas de cobrança como instrumentos econômicos de gestão fica descaracterizada, já que a melhoria da qualidade ambiental, na maioria das vezes, só é conseguida por meio de investimentos em infra-estrutura, que de certa forma pode apresentar resultado fugaz, já que a médio ou longo prazo deverá ser suplantado pelos efeitos da escassez crescente dos recursos naturais.

\footnotetext{
"Metodologia apresentada no item (4.1) do capítulo "Material e Métodos".
} 


\section{Material e Métodos}

Para a consecução dos objetivos propostos no presente trabalho, estudaram-se os fundamentos de várias áreas relacionadas à gestão dos recursos hídricos e seus instrumentos, através de estudo sistematizado, cuja síntese foi apresentada no capítulo revisão bibliográfica. Fundamentalmente, abordou-se cobrança pelo uso da água e legislação ambiental, com ênfase à Política Nacional de Recursos Hídricos.

Após a leitura de material bibliográfico, definiu-se a metodologia apresentada em Souza (1995) como base para o modelo de cobrança pelo uso da água, objeto principal deste trabalho. As modificações na metodologia de cobrança citada visam à eficácia na consecução de seus objetivos e sua aplicabilidade frente à diversidade de fatores e agentes envolvidos na implementação de um instrumento econômico de gestão ambiental. Como forma de avaliar essas modificações, é feita a aplicação do modelo proposto tendo como cenário para a gestão os recursos hídricos da bacia do rio Atibaia.

A área de estudo compreende uma região na qual já vêm ocorrendo conflitos pelo uso da água devido à escassez de recursos e, ainda assim, continua grande a demanda dos diversos usuários de água, pois se trata de pólo regional de desenvolvimento agro-industrial. Também em conseqüência desse quadro de desenvolvimento, existem muitos estudos regionais executados por instituições governamentais e de pesquisa, facilitando o acesso a uma variedade de informações.

Finalmente, para a aplicação do modelo de cobrança proposto, além da metodologia de cobrança citada, são apresentados trabalho de simulação matemática de Azambuja (2000) e outro que relaciona cobrança e capacidade de pagamento desenvolvido por Righetto (2001), ambos aplicados à bacia do rio Atibaia. A abordagem dos aspectos levantados na aplicação serviu às considerações finais a respeito do modelo de cobrança proposto. 


\subsection{Metodologia de Cobrança}

Conforme colocado anteriormente, para a definição da proposta do modelo de cobrança pelo uso de recursos hídricos, tomou-se como base metodológica a apresentada em Souza (1995), que considera a cobrança sobre o lançamento de poluentes e sobre o consumo de água superficial. Essa metodologia foi escolhida porque tem como princípio o fato de o valor cobrado visar às causas da escassez dos recursos hídricos, para então corrigir os problemas causados por essa escassez. Essa distinção é importante à medida que o uso da água deve estar associado diretamente à manutenção de sua qualidade, a fim de se evitar constantes medidas corretivas. Além disso, tendo como princípio a sustentabilidade ambiental, medidas corretivas podem até se tornar insuficientes para a obtenção da qualidade ambiental desejada.

Este preceito de sustentabilidade é traduzido pela "saturação" do corpo de água, cuja medida é dada por um "índice de carga". A metodologia parte da definição do padrão de qualidade do corpo de água receptor - dado pela legislação - e da vazão necessária à manutenção desse padrão para, então, calcular a carga poluente máxima associada a essa concentração do parâmetro de poluição. Na prática, mediante o padrão tem-se o valor a ser cobrado que procura restringir o uso econômico dos recursos hídricos de acordo com a capacidade assimilativa dos mesmos. Assim, pretende-se que o montante arrecadado pela cobrança seja conseqüência de sua aplicação e não seu objetivo.

\subsubsection{Cobrança sobre lançamento de poluentes}

Para a cobrança do uso da água relativo ao lançamento de efluentes, define-se a carga de saturação do corpo receptor - expressão (4.1) - considerada como o limite desejável de um determinado parâmetro de poluição. Essa saturação parte da concentração máxima possível de um parâmetro de poluição no corpo de água (padrão de qualidade) e da vazão de referência mínima do corpo de água receptor, adotada pelo autor como sendo " $\mathrm{Q}_{7,10}$ ".

$$
C_{s}=Q_{7,10} \cdot c
$$

sendo: $\mathrm{C}_{\mathrm{s}}$ a carga de saturação do corpo de água $(\mathrm{mg} / \mathrm{s})$;

$\mathrm{Q}_{7,10}$ a vazão mínima de 7 dias consecutivos com recorrência de 10 anos $(1 / \mathrm{s})$; c a concentração máxima de determinado parâmetro $(\mathrm{mg} / \mathrm{l})$. 
Para que seja considerada a efetiva saturação do corpo d'água, define-se o índice de carga - expressão (4.3) - o qual é concebido como forma de calcular o impacto produzido pelo somatório das cargas dos efluentes de todas as atividades instaladas no trecho do corpo receptor em análise. Logo, esse índice é uma maneira de expressar a capacidade de suporte do corpo receptor com relação a um parâmetro de poluição. Quanto à carga lançada por cada atividade, esta é o produto da vazão do efluente pela concentração de poluente considerado - expressão (4.2).

$$
C_{e}=Q_{e} \cdot c_{e}
$$

sendo: $C_{e}$ a carga de poluente $(\mathrm{mg} / \mathrm{s})$;

$Q_{e}$ a vazão do efluente (1/s);

$c_{e}$ a concentração de poluente em análise $(\mathrm{mg} / \mathrm{l})$.

$I_{c}=\left(C_{s}-\Sigma C_{e}\right) / C_{s}$

sendo: $\mathrm{I}_{\mathrm{c}} \mathrm{o}$ índice de carga;

$\sum \mathrm{C}_{\mathrm{e}}$ o somatório das cargas poluidoras remanescentes, emitidas a montante do ponto de lançamento em questão $(\mathrm{mg} / \mathrm{s})$.

A valoração do uso da água é obtida relacionando-se o índice de carga a um multiplicador " $\mathrm{K}_{\mathrm{c}}$ ", específico para cada poluente, conforme variação do gráfico apresentado na figura (4.1). A metodologia deixa em aberto por meio de qual função deve ser traçado o gráfico, mas, no artigo analisado, utilizou-se o custo médio de sistemas de tratamento conforme equações e intervalos descritos a seguir.

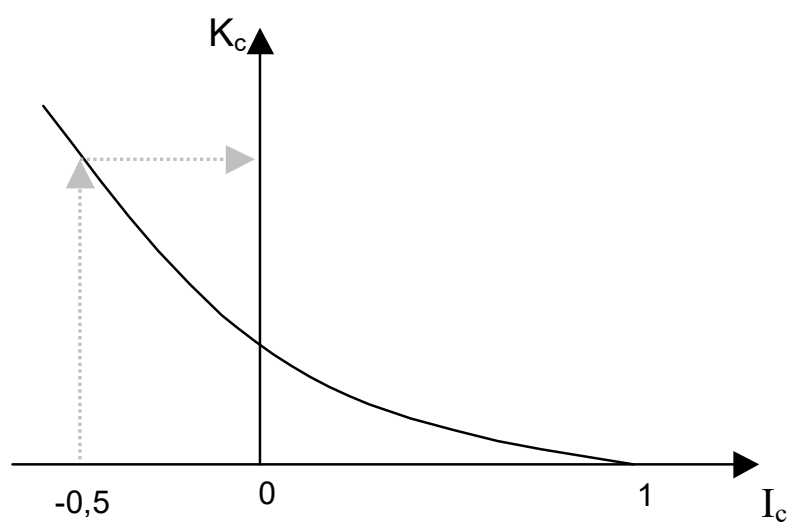

Figura 4.1 - Curva para cobrança (Fonte: Souza, 1995)

As curvas de custo dos sistemas de tratamento de efluentes foram obtidas segundo tratamento matemático de dados bibliográficos encontrados, mediante os 
quais se levantaram os custos para lagoa anaeróbia, lagoa facultativa e sistema de desnitrificação. As equações que melhor representam esses custos totais, com a vazão do efluente nas abscissas (x em $\mathrm{m}^{3} / \mathrm{dia}$ ) e os custos nas ordenadas (y em $10^{6}$ US\$/ano), estão apresentadas na tabela (4.1). Tendo como base essas equações, foram necessários apenas alguns ajustes matemáticos para chegar-se às relações entre o índice de carga $\left(\mathrm{I}_{\mathrm{c}}\right)$ e " $\mathrm{K}_{\mathrm{c}}$ ”, expresso em “(US\$.S)/(1.ano)”, cujos resultados também estão representados na tabela (4.1):

Tabela 4.1 - Curvas de custos totais de sistemas de tratamento de efluentes e equações da curva para cobrança (Adaptado: Souza, 1995)

\begin{tabular}{|c|c|c|}
\hline Lagoa anaeróbia & Lagoa facultativa & Desnitrificação \\
\hline$y=7,12 \cdot 10^{-5} \cdot x^{0,694644}$ & $y=1,31 \cdot 10^{-4} \cdot x^{0,673418}$ & $y=1,17 \cdot 10^{-3} \cdot x^{0,649126}$ \\
\hline$K_{c}=6,15 \cdot 10^{3} \cdot\left(1-I_{c}\right)^{0,69}$ & $K_{c}=1,13 \cdot 10^{4} \cdot\left(1-I_{c}\right)^{0,67}$ & $K_{c}=1,01 \cdot 10^{5} \cdot\left(1-I_{c}\right)^{0,65}$ \\
\hline
\end{tabular}

Considerando o fato de a metodologia deixar em aberto a forma exata de como o multiplicador de valoração da água e o índice de qualidade devem se relacionar, perdem importância estas equações encontradas e ganham destaque os intervalos adotados para o uso de determinada equação a fim de que o valor cobrado aumente sobre maneira conforme diminua a qualidade da água. O critério foi associar o valor da tarifa ao custo de tratamento com lagoa anaeróbia para "I $\mathrm{I}_{\mathrm{c}}$ " variando entre "1 e 0,02 ", ao tratamento por meio de lagoa facultativa para " $\mathrm{I}_{\mathrm{c}}$ " variando entre " 0,02 e 0 " e ao custo de um sistema de desnitrificação para valores menores que zero, quando não é mais desejável o lançamento de efluentes.

Encontrado o valor monetário para determinada quantidade de água, a metodologia define outros multiplicadores que devem considerar alguns fatores essenciais à cobrança pelo lançamento de poluentes. Com o intuito de expressar a sazonalidade temporal (mudanças na vazão do corpo receptor), as diferentes atividades (estimular ou reprimir determinadas atividades) e a eficiência na alocação de recursos financeiros (incentivar sistemas mais eficientes de tratamento de poluentes), define-se um fator de ponderação para a cobrança sobre o lançamento de carga poluente, o qual é determinado pelo gestor da bacia e nunca deverá ser menor do que 1 (um). 
O outro multiplicador definido pela metodologia é para que haja um incentivo aos usuários que levam seus efluentes a concentrações de poluentes menores que aquelas exigidas em lei e para que sejam penalizados os que lançam com concentrações acima daquelas. Assim, utiliza-se a razão entre a concentração do poluente no efluente e a concentração máxima do poluente permitida pela legislação, além dos outros dois multiplicadores, e obtém-se o valor a ser pago pelo uso da água para lançamento de carga de poluição mediante o produto destes três multiplicadores pela vazão do efluente, conforme expressão (4.4):

$$
T_{e}=K_{c} \cdot Q_{e} \cdot U \cdot(c e / c p)
$$

sendo: $\mathrm{T}_{\mathrm{e}} \mathrm{o}$ valor cobrado sobre o lançamento de poluente (US\$/ano);

$\mathrm{U}$ o fator ponderador da sazonalidade, do tipo de usuário e da eficiência do tratamento de efluentes;

$\mathrm{c}_{\mathrm{e}}$ a concentração do poluente no efluente $(\mathrm{mg} / \mathrm{l})$;

$c_{p}$ a concentração máxima dada pelo padrão de emissão $(\mathrm{mg} / \mathrm{l})$.

\subsubsection{Cobrança sobre consumo de água}

Para o cálculo da cobrança sobre o consumo, leva-se em consideração a parcela de água captada e não devolvida ao corpo d'água. Como esta água retirada diminui a capacidade de diluição e depuração do corpo receptor de efluentes, a metodologia adota os mesmos princípios utilizados para a cobrança sobre lançamento de poluentes. A ressalva feita é quanto ao poluente a ser considerado: o consumo de água deve estar relacionado ao parâmetro de poluição cuja situação no corpo receptor esteja mais próxima à saturação.

Assim sendo, para o "poluente crítico", consideram-se os momentos imediatamente anterior e posterior à captação superficial e se definem os índices de carga para estas duas situações de vazões. O índice anterior à captação é definido conforme "4.3" e denomina-se " $\mathrm{I}_{1}$ ". $\mathrm{O}$ índice para a situação imediatamente posterior à captação $\left(\mathrm{I}_{2}\right)$ sofre redução do seu valor associada à vazão consumida e é calculado segundo a expressão (4.5):

$I_{2}=[(Q-Q c o n) . c-\Sigma Q e \cdot c e] /[(Q-Q c o n) . c]$

sendo: $I_{2}$ o índice de carga após a captação em questão; $\mathrm{Q}_{\text {con }}$ a vazão retirada do corpo d'água. 
Substituindo-se esses índices nas expressões adotadas para $\mathrm{K}_{\mathrm{c}}$, são calculados os respectivos multiplicadores " $K_{1}$ " e " $K_{2}$ ", cuja subtração " $K_{2}-K_{1}$ ” é utilizada como forma de o valor cobrado considerar o impacto imposto pela diminuição da vazão do corpo d'água. Finalmente, para o cálculo do valor a ser pago pela captação de água superficial, a metodologia define um multiplicador correspondente ao multiplicador " $U$ " da cobrança para o lançamento de efluentes e considera o somatório das cargas a montante da captação, resultando na expressão (4.6):

$$
T_{e}=\left(K_{2}-K_{1}\right) \cdot S \cdot \Sigma Q_{e} \cdot c_{e} / c_{p}
$$

sendo: $\mathrm{T}_{\mathrm{e}} \mathrm{o}$ valor cobrado sobre a quantidade de água retirada (US\$/ano);

$\mathrm{K}_{2}$ o coeficiente multiplicador posterior à captação (US\$.s/l.ano);

$\mathrm{K}_{1}$ o coeficiente multiplicador anterior à captação (US\$.s/l.ano);

$\mathrm{S}$ o fator ponderador da sazonalidade e do tipo de atividade; $\sum \mathrm{Q}_{\mathrm{e}} \cdot \mathrm{c}_{\mathrm{e}} \mathrm{o}$ somatório das cargas de emissão a montante da captação (1/s).

O princípio desta metodologia apresentada é a base do modelo de cobrança sobre o uso dos recursos hídricos proposto no presente trabalho (capítulo 5), o qual modifica aspectos da metodologia base visando à aplicabilidade da cobrança e, até mesmo, a eficiência frente aos objetivos propostos. Sobre a aplicabilidade, nota-se que, se não houver poluição a montante da captação de água, " $\mathrm{I}_{1}$ " $\mathrm{e}$ " $\mathrm{I}_{2}$ " serão iguais a um e, conseqüentemente, " $K_{1}$ " e " $K_{2}$ " serão iguais a zero, ou seja, o usuário que deveria estar sendo cobrado pelo consumo de água não pagaria nada.

Em nome da eficiência, uma das medidas adotadas na nova proposta é o uso da capacidade de pagamento dos agentes econômicos na valoração da água. Assim sendo, servindo como parâmetro para esta adoção, apresenta-se uma análise da capacidade de pagamento dos setores industrial e agrícola da bacia do rio Atibaia baseada em Righetto (2001).

\subsection{Capacidade de Pagamento}

O objetivo da utilização da capacidade de pagamento como parâmetro da cobrança pelo uso da água é incentivar os agentes econômicos a diminuírem as “externalidades" causadas por suas atividades e a buscar a racionalização desse uso a fim de evitar o comprometimento da qualidade ambiental além do limite desejável. A sua utilização define a magnitude do impacto sobre as finanças dos usuários advindo da cobrança pelos recursos hídricos, tornando-se a medida de quando a 
implementação da tarifa induz à "otimização" do sistema ou, para situações extremas, não altera o comportamento do agente ou acarreta a inadimplência deste.

Estas últimas observações, apesar de simples, são decorrência de desdobramentos econômicos bem mais complexos, sobre os quais podem ser levantadas várias questões dependentes da estrutura do mercado no qual atuam os agentes. Para a eficácia do sistema de cobrança, deve estar claro "quem paga a conta" e quais os indicadores devem ser a base da resposta a esse questionamento. A proposta é que a capacidade de pagamento mensurada adequadamente seja o divisor de águas da cobrança, indicando o preço limite associado à qualidade e à quantidade de água desejadas.

Entretanto, a mensuração desta capacidade trata-se de tarefa difícil. Obter com exatidão um valor monetário por unidade de consumo de água, mediante o qual se saiba o impacto financeiro que acarretará no sistema de gestão dos recursos hídricos, deverá ser possível somente após algum tempo de aplicação de determinado valor. Para tanto, podem ser estimados valores iniciais que permitam a análise do impacto da cobrança frente à estrutura financeira dos agentes econômicos, tendo como objetivo adequar a intensidade do uso dos recursos hídricos à escassez de água.

Alguns autores, entre eles Araújo (1998) e Ribeiro e Lanna (1999), apontam a importância da determinação da capacidade de pagamento para a efetiva implantação da cobrança pelo uso da água, argumentando sobre a necessidade da diferenciação da tarifa em função da capacidade de pagamento do usuário a fim de que o aumento de custo de produção não inviabilize a atividade, salvo situação na qual o contrário seja o desejo da comunidade. Apesar de a preocupação original dos autores ser evitar impactos sociais e econômicos advindos da cobrança, seus trabalhos apontam para o fato de a capacidade de pagamento também vir a ser utilizada para evitar impactos ambientais. Logo, o sistema de cobrança pode impor limites a partir dos quais impactos positivos para o ambiente justifiquem outros tipos de impactos negativos, mesmo porque, no médio prazo, estes devem significar um maior equilíbrio nas relações sócio-econômicas.

A degradação ambiental provocada pela escassez de água pode significar um impacto de tal magnitude que conseqüências sociais maiores extrapolem a escala local e a sustentabilidade do desenvolvimento. Essa é a maneira como a capacidade 
de pagamento deve ser vista no modelo de cobrança proposto neste trabalho: um valor a ser associado ao preço cobrado pela água a fim de inviabilizar seus usos excessivos, cujo limite deve ser definido por um sistema gestor em que todos agentes estejam representados.

Araújo (1998), mesmo concordando com a dificuldade em se determinar a capacidade de pagamento, também aponta para a determinação de um valor "custo operacional $/ \mathrm{m}^{3}$ de água necessária" como forma de avaliar o impacto da cobrança sobre a atividade. Acerca desse quociente, faz a ressalva para que seja considerada a quantidade de água necessária à atividade e não a consumida por determinado usuário, evitando, assim, distorções que favoreçam àquele agente menos eficiente quanto ao uso de recursos hídricos. Finalmente, indica a possibilidade de a cobrança financiar usuários com pequena capacidade de pagamento, quando houver demandas sócio-econômicas.

A seguir, apresenta-se análise sobre capacidade de pagamento feita com base em Righetto (2001), o qual avalia o impacto da cobrança sobre os irrigantes na bacia do rio Atibaia buscando indicar o valor da capacidade de pagamento do setor agrícola considerando o "custo operacional $/ \mathrm{m}^{3}$ de água necessária". Para o setor industrial, em função dos tipos de dados disponíveis, é feita uma avaliação de valores de referência da capacidade de pagamento, os quais são perfeitamente aplicáveis aos objetivos deste trabalho. Assim, entre as várias técnicas existentes, algumas metodologias serão apresentadas e utilizadas para a determinação da capacidade de pagamento desses setores na bacia do rio Atibaia.

\subsubsection{Setor agrícola}

Para análise da capacidade de pagamento do irrigante, Righetto (2001) tomou como base trabalhos de Araújo e de França e Pereira*. O primeiro trabalho utiliza metodologia baseada em dados obtidos de questionários que identificam os usuários e caracterizam o sistema investigando três variáveis: tamanho da área utilizada,

\footnotetext{
*ARAÚJO, J.C. Aspectos de Gestão e do Uso Econômico dos Recursos Hídricos no Estado do Ceará. Fortaleza: CNPq/COGERH, 1997. (Relatório Técnico, CNPq/COGERH)

FRANÇA, F. M. C.; PEREIRA, J. A. Análise Agroeconômica e Capacidade de Pagamento do Pequeno Irrigante no Nordeste. Estudos Econômicos e Sociais. Fortaleza: Secretaria Nacional de Irrigação/BNB/ETENE, 1990. (Secretaria Nacional de Irrigação/BNB/ETENE)
} 
localização da atividade e tipo de atividade do agente. De posse dos dados, é feita avaliação estatística visando à definição do preço da água por uso, à determinação da capacidade de pagamento e à obtenção do volume de água demandado aos diversos usos. Para a estimativa da capacidade de pagamento, Araújo utiliza 1\%* do faturamento bruto dividido pelo volume médio de água necessário para a produção ou, baseando-se no rendimento líquido, $5 \%$ deste rendimento dividido pelo mesmo volume ou " $0,01 \mathrm{R} \$ / 1000 \mathrm{~m}^{3}$ " caso o rendimento líquido seja menor que zero.

O trabalho de França e Pereira analisa o caso de irrigantes do nordeste mediante dados de custos com a lavoura, da receita bruta obtida com a venda da safra e do montante necessário para a subsistência da família, cujo resultado líquido é a renda relacionada com a capacidade de pagamento pelo uso da água. Detalhando um pouco mais a renda bruta, esta corresponde ao total anual da produção, ao aluguel de animais e equipamentos, à aposentadoria do irrigante e à mão-de-obra familiar prestada a terceiros. Dessa renda bruta são subtraídos custos operacionais, custos fixos incidentes sobre a propriedade, valor da mão-de-obra familiar, dispêndios com água e energia elétrica e despesas com a subsistência familiar, resultando na renda líquida correspondente à capacidade de pagamento da água para irrigação.

Para o estudo da bacia do rio Atibaia, a obtenção da capacidade de pagamento dos irrigantes tem por base a metodologia desenvolvida por França e Pereira e informações adicionais, como volume de água consumida pelas culturas e dados de custos e receitas, obtidas em Araújo e no periódico "Agrianual 2000". Neste periódico, as receitas médias e os custos médios são estabelecidos por setor e para os principais centros produtores, o que possibilita o cálculo da capacidade de pagamento dos irrigantes da bacia do rio Atibaia para as culturas de cana, milho, feijão e frutas (abacate, pêssego, uva e goiaba), culturas existentes na bacia.

Têm-se, também, as informações relativas às áreas cultivadas e ao total consumido pela irrigação na bacia, obtidas da Secretaria do Meio Ambiente do Estado de São Paulo (SMA, 1994). A partir desses dados, pode-se calcular os totais consumidos para cada cultura irrigável da bacia do rio Atibaia mediante o volume de água gasto em um hectare no período de um ano, conforme tabela (4.2):

\footnotetext{
* Valor baseado em estudo de tarifação da água no estado de São Paulo: "Cobrança pelo uso da água. São Paulo: CORHI, 1997. (Relatório Técnico 001/97, SMA/CETESB/DAEE)”
} 
Tabela 4.2 - Consumo anual de água por cultura na bacia do rio Atibaia (Adaptado: Righetto, 2001)

\begin{tabular}{|c|c|c|c|c|}
\hline Culturas & $\begin{array}{c}\mathbf{A}= \\
\text { área plantada } \\
\text { (ha) }\end{array}$ & $\begin{array}{c}B= \\
\text { consumo } \mathrm{p} / \text { cultura } \\
\left(\mathrm{m}^{3} / \mathrm{ha}\right)\end{array}$ & $\begin{array}{c}C=A \times B \\
\text { consumo de água } \\
\left(\mathrm{m}^{3}\right)\end{array}$ & $\begin{array}{c}100 . \mathrm{C} / \Sigma \mathrm{C}= \\
\text { percentual } \mathrm{p} / \text { cultura } \\
(\%)\end{array}$ \\
\hline cana & 1.647 & 22.000 & 36.234 .000 & 15,78 \\
\hline milho & 7.530 & 6.000 & 45.180 .000 & 19,68 \\
\hline frutas & 7.935 & 15.000 & 119.025 .000 & 51,85 \\
\hline feijão & 2.077 & 5.000 & 10.385 .000 & 4,52 \\
\hline outras & 2.690 & 6.971 & 18.752 .000 & 8,17 \\
\hline
\end{tabular}

Para o cálculo da capacidade de pagamento dos irrigantes, tabela (4.3), não foi possível a obtenção de dados da subsistência da família conforme proposto originalmente. Na proposta original, são simuladas várias porcentagens em relação à renda líquida em dinheiro como forma de se obter esses valores, mas, sendo objetivo deste trabalho utilizar um valor monetário por quantidade de água consumida como capacidade de pagamento do agente econômico (tarefa complexa que pode exigir a participação de um grupo de profissionais), é apresentada apenas a capacidade de pagamento referente ao gasto de $90 \%$ da renda com a subsistência da família. Também considerando esse objetivo, para representar a capacidade dos irrigantes de frutas são adotados apenas os valores referentes ao abacate, cultura com valores menores da capacidade de pagamento entre as frutas cultivadas na região.

Tabela 4.3 - Capacidade de pagamento por cultura na bacia do rio Atibaia referente ao gasto de $90 \%$ da renda com subsistência familiar (Adaptado: Righetto, 2001)

\begin{tabular}{|c|c|c|c|c|c|c|}
\hline Culturas & $\begin{array}{c}A= \\
\text { renda bruta } \\
\text { (US\$/ha) }\end{array}$ & $\begin{array}{c}B= \\
\text { custos } \\
\text { (US\$/ha) }\end{array}$ & $\begin{array}{c}C= \\
90 \% .(A-B) \\
\text { (US\$/ha) }\end{array}$ & $\begin{array}{c}D= \\
A-(B+C) \\
(U S \$ / h a)\end{array}$ & $\begin{array}{c}E= \\
\text { consumo } \\
\left(1000 \mathrm{~m}^{3} / \mathrm{ha}\right)\end{array}$ & $\begin{array}{c}D / E= \\
\text { capacidade } \\
\left(\mathbf{U S} \$ \mathbf{1 0 0 0 m ^ { 3 } )}\right.\end{array}$ \\
\hline cana & 444,00 & 484,30 & - & - & 22,00 & - \\
\hline milho & 615,00 & 468,09 & 132,22 & 14,69 & 6,00 & 2,45 \\
\hline abacate & $2.047,00$ & 841,00 & $1.085,40$ & 120,60 & 15,00 & 8,04 \\
\hline feijão & 922,00 & $2.585,02$ & - & - & 5,00 & - \\
\hline
\end{tabular}


$\mathrm{Na}$ tabela (4.3) não existem valores da capacidade de pagamento para as culturas de cana-de-açúcar e feijão porque essas culturas apresentaram capacidade negativa, o que implicaria na definição de um valor mínimo conforme sugerido por Araújo, ou outro que o comitê de bacia considere adequado à manutenção da qualidade ambiental. Como no capítulo referente à aplicação do modelo de cobrança podem ser utilizadas as outras culturas, este fato não altera o desenvolvimento do trabalho.

\subsubsection{Setor industrial}

Diferente da análise para a irrigação, na análise da capacidade de pagamento do setor industrial, Righetto (2001) evita definir um valor monetário específico associado a essa capacidade. Ponderando que não existe uma medida única deste valor, coloca que o mesmo depende do objetivo para o qual está sendo realizada a análise. Assim, coloca que o trabalho não visa a apresentar uma proposta fechada da capacidade de pagamento, mas apenas sugerir se uma empresa é capaz de honrar ou não os valores estipulados pela cobrança. No entanto, ao mesmo tempo, afirma que a capacidade de pagamento pode ser utilizada como um indicador do valor que induziria os agentes econômicos a minimizar a utilização dos recursos hídricos, objetivo do modelo de cobrança proposto.

Para o desenvolvimento do trabalho, o autor considera a análise financeira adequada à avaliação da capacidade de indústrias cobrirem suas despesas, ou seja, capacidade de pagamento ou liquidez. Consideram-se, também, as informações contábeis suficientes à observação de qual é o impacto de uma tarifa na estrutura financeira. Logo, como o objetivo é avaliar a capacidade de pagamento do setor industrial em termos monetários, analisam-se financeiramente os principais usuários industriais de água bruta da bacia do rio Atibaia.

As técnicas utilizadas para que a análise financeira indique a capacidade de pagamento do setor industrial são as mesmas desenvolvidas para a concessão de crédito financeiro. Para a análise, utiliza-se o quadro demonstrativo de resultados de uma empresa, exemplificado pela figura (4.2), mediante o qual se verifica a sobra ou a falta de recursos. Os resultados correspondentes ao lucro operacional e ao lucro líquido indicam se existe lucro ou prejuízo, ou seja, podem indicar a existência de capacidade de pagamento do agente econômico. 


\begin{tabular}{||l|l||}
\hline \multicolumn{1}{|c||}{ DEMONSTRAÇ̃̃O DOS RESULTADOS } & (US\$) \\
\hline Vendas Líquidas & \\
\hline Lucro Bruto & \\
\hline (-) Despesas Operacionais & \\
\hline (-) Despesas/Receitas Financeiras & \\
\hline (+/ -) Resultado Equivalência Patrimonial & \\
\hline$(+/-)$ Outros Resultados Operacionais & \\
\hline Lucro Operacional & \\
\hline (+/ -) Resultado não Operacional & \\
\hline (+/ -) Saldo da Correção Monetária & \\
\hline Lucro Antes do IR & \\
\hline Lucro Líquido & \\
\hline \hline
\end{tabular}

Figura 4.2 - Quadro demonstrativo de resultados (Fonte: Righetto, 2001)

Complementando a análise do demonstrativo de resultados, o autor também analisa a estrutura de capital, a elasticidade preço da demanda e alguns índices financeiros, como solvência, endividamento e liquidez, que medem a capacidade de pagamento das dívidas de uma empresa dentro dos prazos de vencimento. O conjunto dessas análises é considerado adequado para indicar o comportamento da empresa quando cobrada pelo uso da água. Entretanto, como para a aplicação do modelo de cobrança proposto é necessário chegar-se a um valor monetário da capacidade de pagamento, e não ao confronto entre a saúde financeira da empresa e o valor a ser cobrado pelo uso da água, será apresentada a parte do estudo na qual o autor analisa uma empresa do ramo têxtil, caracterizada conforme dados da figura (4.3), para a qual é indicado um valor da capacidade de pagamento.

\begin{tabular}{|c|c|c|c|c|}
\hline \multicolumn{5}{|c|}{ Estrutura do Capital } \\
\hline 1998 & (mil) & & US\$ & 1,21 \\
\hline \multicolumn{2}{|c|}{ Ativo } & & \multicolumn{2}{|c|}{ Passivo } \\
\hline AC & $4.146,38$ & & 756,75 & $P C$ \\
\hline RLP & 185,46 & 185,46 & - & ELP \\
\hline AP & $2.010,27$ & $2.010,27$ & $5.583,71$ & $\mathrm{PL}$ \\
\hline 1999 & (mil) & & US\$ & 1,80 \\
\hline \multicolumn{2}{|c|}{ Ativo } & & \multicolumn{2}{|c|}{ Passivo } \\
\hline AC & $3.365,72$ & & 588,53 & $P C$ \\
\hline$R L P$ & 59,41 & 59,41 & - & ELP \\
\hline AP & $1.438,01$ & $1.438,01 \leftarrow$ & $4.274,05$ & $\mathrm{PL}$ \\
\hline
\end{tabular}

\begin{tabular}{|c|c|c|c|c|c|}
\hline \multicolumn{6}{|c|}{ Fluxo de Recursos } \\
\hline \multicolumn{6}{|c|}{$1998 / 1999 \quad$ (mil) } \\
\hline Ativo & Passivo & & Ativo & Passivo & \multirow{5}{*}{$\begin{array}{c}(168,22) \\
- \\
(1.309,65)\end{array}$} \\
\hline $4.146,38$ & 756,75 & $(780,66)$ & $3.365,72$ & 588,53 & \\
\hline 185,46 & - & $(126,05)$ & 59,41 & - & \\
\hline $2.010,27$ & $5.583,71$ & $(572,26)$ & $1.438,01$ & $4.274,05$ & \\
\hline \multicolumn{2}{|l|}{$6.342,11$} & $(1.478,97)$ & $4.863,14$ & & \\
\hline & & \multicolumn{2}{|c|}{ Índice } & Ano & \\
\hline & & & & 1999 & 1998 \\
\hline & & \multicolumn{2}{|c|}{ Capital Circulante Líquido } & $3.389,63$ & $2.777,19$ \\
\hline & & \multicolumn{2}{|c|}{ Liquidez Corrente } & 5,48 & 5,72 \\
\hline & & \multicolumn{2}{|c|}{ Liquidez Seca } & 5,17 & 5,38 \\
\hline & & \multicolumn{2}{|c|}{ Liquidez Imediata } & 0,00 & 0,03 \\
\hline & & \multicolumn{2}{|c|}{ Liquidez Geral } & 5,72 & 5,82 \\
\hline & & \multicolumn{2}{|c|}{ Solvência Geral } & 8,38 & 8,26 \\
\hline & & \multicolumn{2}{|c|}{ Endividamento Total } & 0,14 & 0,14 \\
\hline & & \multicolumn{2}{|c|}{ Imobilização do PL } & 0,36 & 0,34 \\
\hline & & \multicolumn{2}{|c|}{ Ret. Invest. Operacional } & 0,13 & 0,17 \\
\hline & & \multicolumn{2}{|c|}{ Rentabilidade do Ativo } & 0,12 & 0,17 \\
\hline & & \multicolumn{2}{|c|}{ Rentabilidade do PL } & 0,14 & 0,19 \\
\hline & & \multicolumn{2}{|c|}{ Margem Bruta } & 0,25 & 0,29 \\
\hline & & \multicolumn{2}{|c|}{ Margem Operacional } & 0,11 & 0,13 \\
\hline & & \multicolumn{2}{|c|}{ Margem Líquida } & 0,11 & 0,13 \\
\hline
\end{tabular}

\begin{tabular}{|l|r|r|}
\hline \multicolumn{3}{|c|}{ DEMONSTRAÇÃO DOS RESULTADOS } \\
\hline & \multicolumn{1}{|c|}{$\mathbf{3 1 / 1 2 / 9 8}$} & \multicolumn{1}{c|}{$\mathbf{3 1 / 1 2 / 9 9}$} \\
\hline Receita Operacional Bruta & 7.098 & 6.238 \\
\hline Receita Operacional Liquida & 7.098 & 6.238 \\
\hline Lucro Bruto & 1.807 & 1.818 \\
\hline Res. Atividade & 513 & 680 \\
\hline$(-)$ Despesa Financeiras & $(4)$ & $(67)$ \\
\hline$(+)$ Receita Financeira & 246 & 195 \\
\hline Lucro Operacional & 754 & 808 \\
\hline Lucro Líquido & 754 & 808 \\
\hline
\end{tabular}

Figura 4.3 - Balanço financeiro de empresa têxtil (Fonte: Righetto, 2001) 
Analisando-se os dados dessa empresa localizada na bacia do Atibaia, a estrutura de capital é caracterizada como saudável. Particularmente, considerando a solvência geral (patrimônio líqüido) como uma medida da capacidade de pagamento, esta empresa possui uma sobra de recursos no valor de 5.585,36 mil US\$ em 1998 e 4.274,61 mil US\$ em 1999 e, no demonstrativo de resultados, pode-se notar que em 1998 e em 1999 houve lucro líquido positivo de 754 mil US\$ e 808 mil US\$, respectivamente. Quanto à análise das elasticidades preço da demanda, esta só seria possível depois de definido o valor da cobrança, e só após essa análise é que se poderia afirmar com exatidão os efeitos dos valores cobrados sobre o agente econômico.

Prevendo esta dificuldade na definição exata da capacidade de pagamento mediante análise financeira, a Secretaria dos Recursos Hídricos do Estado do Ceará, citando Araújo (1998), sugere que, visando à implementação da cobrança pelo uso da água, quando necessário pode ser estimado um valor inicial para a capacidade de pagamento igual a $1 \%$ do faturamento bruto ou $5 \%$ do faturamento líqüido divididos pela quantidade de água necessária à produção. Portanto, mesmo existindo dificuldades, podem ser encontradas maneiras de determinar-se a capacidade de pagamento que, tratando-se de variável econômica, pode ajudar a cobrança pelo uso dos recursos hídricos a ser um eficaz instrumento econômico de gestão ambiental, que leva à diminuição da escassez de água ao mesmo tempo que apresenta uma racionalidade econômica.

\subsection{Modelagem Matemática}

Como mencionado no início deste capítulo, o objetivo principal deste trabalho é desenvolver um modelo de cobrança baseado na metodologia apresentada no item (4.1). As modificações na metodologia citada visam à aplicabilidade deste instrumento econômico de gestão ambiental frente à diversidade de fatores envolvidos em sua implementação, o que levou à adoção de simulação matemática desenvolvida por Azambuja (2000) como forma de aprimoramento da cobrança, já que a modelagem deverá indicar o grau de incerteza, a divisibilidade e a interferência de determinado uso na disponibilidade da água, adequando este recurso às características desejadas pelo sistema de cobrança. 
Os modelos podem ser definidos como representações simplificadas de sistemas reais que se desejam analisar para melhor compreendê-los, inclusive sistemas naturais aquáticos. Para Porto e Azevedo (1997), as situações reais são demasiadamente complexas para serem representadas na sua íntegra e, em geral, grande parte desta complexidade é irrelevante para o problema que se quer resolver. Por esta razão, procura-se conceber um modelo da realidade que considera apenas a essência do sistema, ou seja, apenas os aspectos relevantes para a solução do problema. Modelar e simplificar são conceitos indissociáveis.

Sendo a água um recurso de transporte e armazenamento dispendiosos, cuja disponibilidade para uns depende da utilização por outros e com incertezas associadas à sua natureza, como quantidade e qualidade sazonais, a alocação ótima desejada pelo sistema necessita da construção de cenários que ofereçam aos usuários algum grau de certeza da disponibilidade deste produto. A modelagem matemática deve contribuir na formulação destes cenários, fornecendo a quantificação das interferências entre os usos da água, as possibilidades advindas do manejo de reservatórios e a probabilidade de ocorrência de determinados cenários desejados. Ao possibilitar a avaliação da disponibilidade hídrica, fundamental para programas e decisões de aproveitamento múltiplo e integrado da água, e ainda para a minimização de impactos ambientais, a modelagem também integrará os instrumentos de gestão ambiental.

Azambuja (2000) utilizou o modelo Modsimp 32*, que associa a simulação numérica e a modelagem em rede de fluxo, para determinar a disponibilidade hídrica da bacia do rio Piracicaba com base nas demandas previstas para o ano de 2010. O balanço hídrico efetuado fornecerá as informações necessárias à aplicação do modelo de cobrança proposto no rio Atibaia, integrante da bacia do Piracicaba. Logo, mediante o trabalho de modelagem executado, apresentado a seguir, serão determinadas as vazões dos corpos d'água, ou seja, desenhado o quadro de escassez de água da bacia hidrográfica.

\footnotetext{
* O Modsimp 32 é uma versão atualizada do modelo Modsim, modelo de domínio público que foi desenvolvido na Colorado State University, sobre o qual podem ser encontradas informações em "LABADIE, J. W.; BODE, D. A.; PINEDA, A. M. Network Model for Decision-Support in Municipal Raw Water Supply. Water Resources Bulletin. 1986. Vol.22, No.6.”
} 


\subsubsection{Modsimp 32}

O Modsimp 32 é um modelo de simulação capaz de efetuar otimização ${ }^{*}$, é próprio à execução de balanço hídrico de uma bacia, ou sub-bacia, da qual são necessários três tipos de informações básicas: dados hidrológicos, dados de especificação de critérios operacionais e demandas do sistema. No modelo, a bacia hidrográfica é representada por uma rede de fluxo, ilustrada na figura (4.4), que nada mais é do que a representação dos corpos d'água como seqüência de nós e arcos. Os nós representam reservatórios e pontos de demanda, ou apenas pontos de passagem de água na rede, e os arcos representam rios e canais que interligam os nós e que possuem um valor associado à dificuldade para sua transposição.
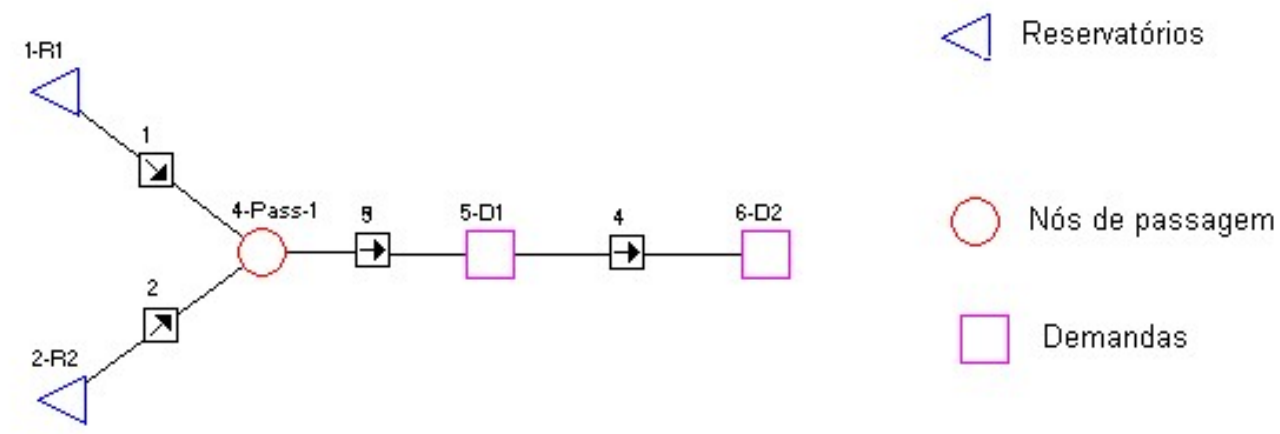

Figura 4.4 - Representação de uma rede de fluxo (Fonte: Azambuja, 2000)

Cada estrutura da rede deve estar associada às características do que ela representa. Para os nós, quando representarem reservatórios, devem ser fornecidos os volumes máximos e mínimos de armazenamento, o nível que se deseja atingir e as taxas de infiltração e evaporação. Os nós que representam as demandas devem conter o valor da demanda de água e os nós de passagem devem estar relacionados ao nó de montante e ao nó de jusante.

Quanto aos trechos que interligam os nós, estes devem apresentar as capacidades máxima e mínima - vazões que podem ser fixas para todo o período de simulação ou variar no tempo - e o "custo" por unidade de fluxo. O custo não precisa ser econômico, podendo representar fatores hierárquicos ou de ponderação que sirvam para colocar as alternativas operacionais em ordem de prioridade. Pode

\footnotetext{
* A simulação é uma técnica de modelagem utilizada no computador para representar as principais características do sistema através de descrição matemática. Os modelos de otimização podem ajudar a minimizar futuros desperdícios, maximizando a produção de energia ou minimizando a liberação de água do sistema (Azevedo et al, 1998).
} 
também ser usado para avaliar compensações (trade-offs) entre usos conflitantes durante períodos de escassez hídrica, servindo de apoio à tomada de decisões (Azevedo et al, 1998).

Exemplo de utilização de custo de alocação de água na rede é observado analisando-se o caso da bacia do Atibaia, na qual a Secretaria do Meio Ambiente (SMA, 1994) estipulou a vazão mínima de $15 \mathrm{~m}^{3} / \mathrm{s}$ em Paulínea, região altamente industrializada cuja vazão mínima é necessária para diluir os efluentes lançados ao corpo d'água. Como o modelo tem o objetivo de realizar um balanço de massa minimizando o custo de alocação de água na rede, ajusta-se o custo do trecho correspondente à vazão desejada de modo a torná-la uma prioridade e, assim, seja contemplada na simulação otimizada que determina a quantidade de água nos vários pontos da rede de fluxo.

O modelo Modsimp 32 trabalha em ambiente Windows e pode ser utilizado para a análise de problemas de curto ou longo prazo, com intervalos de tempo semanais ou mensais. Ele tem como entrada principal vazões naturais, que podem ser fornecidas por série de dados fluviométricos históricos ou sintéticos, mas cujo período deve ser o mesmo para todos os nós da rede de fluxo. Os resultados do modelo possibilitam o cálculo da probabilidade de existência de água de acordo com várias alternativas operacionais e de utilização de recursos hídricos.

\subsubsection{Aplicação do Modsimp 32}

Em Azambuja (2000), o modelo foi aplicado à bacia do Piracicaba, mas, como o caso da cobrança será aplicado apenas à sub-bacia do Atibaia, será apresentada a parte do estudo relativa a esta região. Conforme observado no início deste capítulo, trata-se de região de grande desenvolvimento econômico (grandes centros urbanos, industrialização intensa e agricultura moderna) cujo cenário regional de conflito pelo uso da água estimula a realização de vários estudos, tanto por parte do governo quanto por parte de instituições de pesquisa, o que também favorece a existência de informações e dados necessários à aplicação do modelo Modsimp32.

Já citado anteriormente, relatório da Secretaria do Meio Ambiente do Estado de São Paulo (SMA, 1994), visando ao reenquadramento dos corpos d'água da bacia 
do rio Piracicaba, apresenta estudos de metas ambientais para os quais foram geradas previsões de demandas de água e cargas poluidoras de DBO. Para a sub-bacia do rio Atibaia, foram feitos levantamentos dos dados baseados no uso do solo e da água, resultando numa divisão em quatro trechos denominados compartimentos ambientais, listados a seguir e apresentados na figura (4.5): Compartimento Ambiental Atibaia (C.ATI), Compartimento Ambiental Itatiba (C.ITA), Compartimento Ambiental Pinheiros/Anhumas (C.PAN) e Compartimento Ambiental Salto Grande (C.SGR).

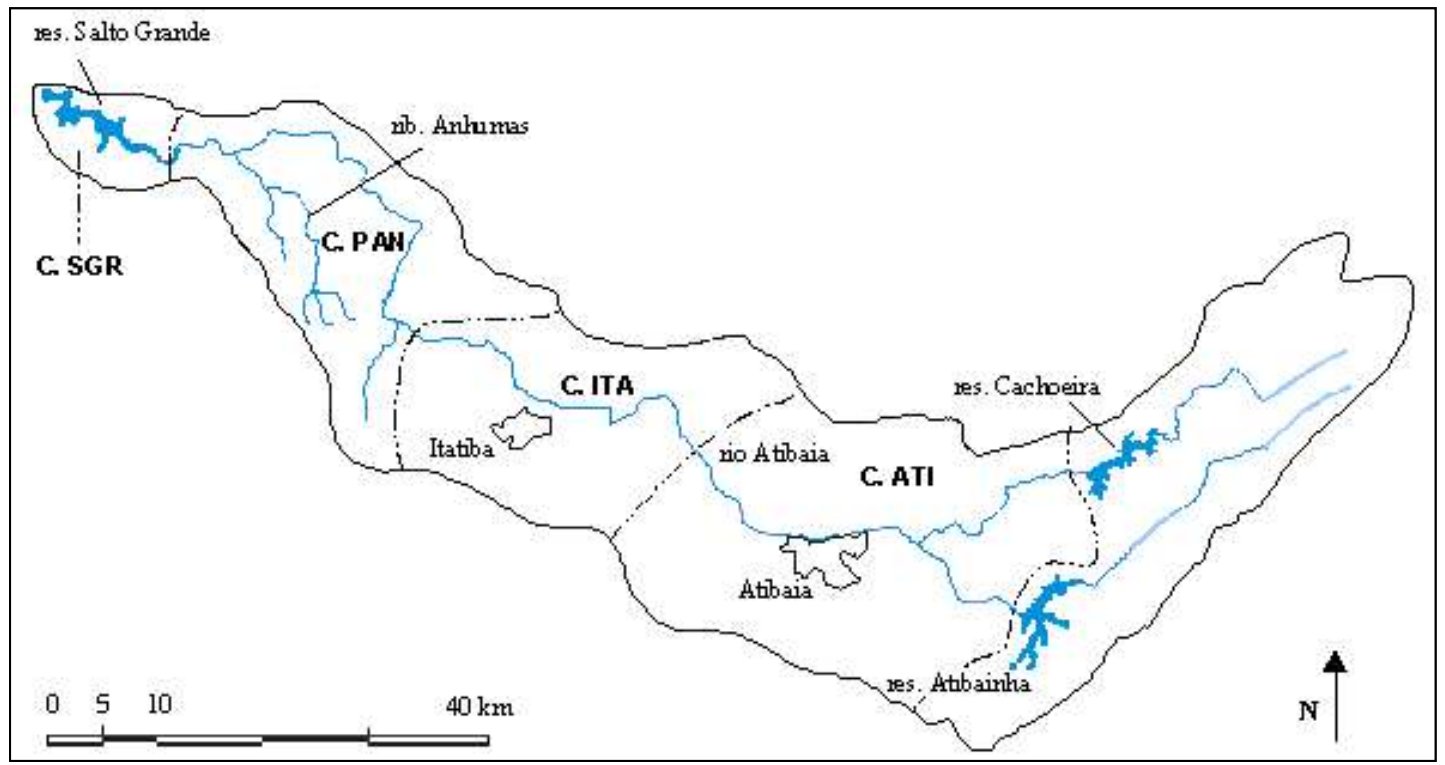

Figura 4.5 - Compartimentos ambientais da sub-bacia Atibaia

A construção da rede de fluxo que representa a sub-bacia do rio Atibaia teve como base SMA (1994), ou seja, considerou-se as reversões para São Paulo e Jundiaí e a divisão da região em compartimentos ambientais, conforme figura (4.6). $\mathrm{Na}$ cabeceira da bacia situa-se o Sistema Cantareira composto por cinco reservatórios, sendo que dois (reservatórios Cachoeira e Atibainha) estão dentro dos limites da sub-bacia em questão e contribuem com o abastecimento da cidade de São Paulo. 


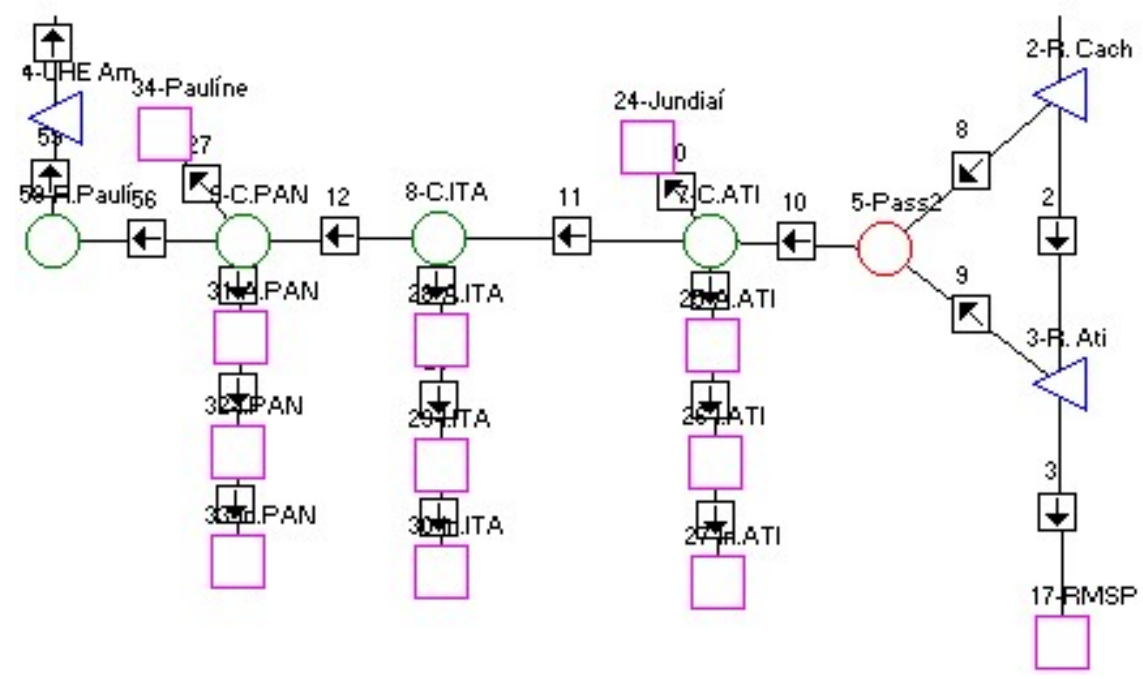

Figura 4.6 - Rede de fluxo da bacia do Atibaia (Adaptado: Azambuja, 2000)

As demandas utilizadas pelos usuários de água são aquelas determinadas para o ano de 2010, descritas na tabela (4.4), e são feitas ao final de cada compartimento ambiental de acordo com cada finalidade, sendo elas: abastecimento urbano (A. compartimento ambiental), irrigação (I. compartimento ambiental), industrial (In. compartimento ambiental) e usinas de cana (U. compartimento ambiental). Como exemplo de representação dessas demandas pode ser observada a figura (4.6), na qual o Compartimento Ambiental Itatiba (C. ITA) possui as demandas número "28" para abastecimento urbano (A. ITA), “29” para irrigação (I. ITA) e “30” para captação industrial (In. ITA).

Tabela 4.4 - Demandas na bacia do Atibaia - ano 2010 (Fonte: SMA, 1994)

\begin{tabular}{||c|l|c|c||}
\hline $\begin{array}{c}\text { compartimento } \\
\text { ambiental }\end{array}$ & setor usuário & $\begin{array}{c}\text { vazão de } \\
\text { captação }\left(\mathbf{m}^{\mathbf{3}} / \mathbf{s}\right)\end{array}$ & $\begin{array}{c}\text { uso consuntivo } \\
\left(\mathrm{m}^{3} / \mathrm{s}\right)\end{array}$ \\
\hline \multirow{3}{*}{ C.ATI. } & industrial & 0,003 & 0,003 \\
\cline { 2 - 4 } & urbano & 0,638 & 0,223 \\
\cline { 2 - 4 } & irrigação & 0,479 & 0,479 \\
\hline \multirow{3}{*}{ C.ITA. } & industrial & 0,311 & 0,039 \\
\cline { 2 - 4 } & urbano & 1,745 & 1,577 \\
\cline { 2 - 4 } & irrigação & 0,563 & 0,563 \\
\hline \multirow{3}{*}{ C.PAN. } & industrial & 6,749 & 0,142 \\
\cline { 2 - 4 } & urbano & 5,223 & 3,022 \\
\cline { 2 - 4 } & irrigação & 0,575 & 0,575 \\
\hline \multirow{3}{*}{ C.SGR. } & industrial & - & - \\
\cline { 2 - 4 } & urbano & - & 0,023 \\
\cline { 2 - 5 } & irrigação & 0,023 & 6,646 \\
\hline \multicolumn{2}{|c|}{ total da bacia } & 16,309 & \\
\hline
\end{tabular}


Séries de vazões históricas, entrada do modelo, foram obtidas no site do Centro de Estudos Nucleares Aplicados da Escola de Agronomia Luiz de Queiroz (Cena - ESALQ), referentes aos postos descritos na figura (4.7). Analisando-se a série histórica, foi necessária a geração de vazões mensais utilizando um modelo de séries temporais. Para a aplicação das séries de vazões no modelo deve ser considerado um período comum de dados dos postos fluviométricos, assim, em função da menor amostra de dados apresentada pelo posto 4D-021, utilizou-se período compreendendo os anos de 1973 a 1993 para todos os nós da rede de fluxo. Finalmente, fez-se verificações da rede utilizando um ano médio de vazões mensais, mediante o qual se analisou a relação entre os usos conflitantes da bacia.

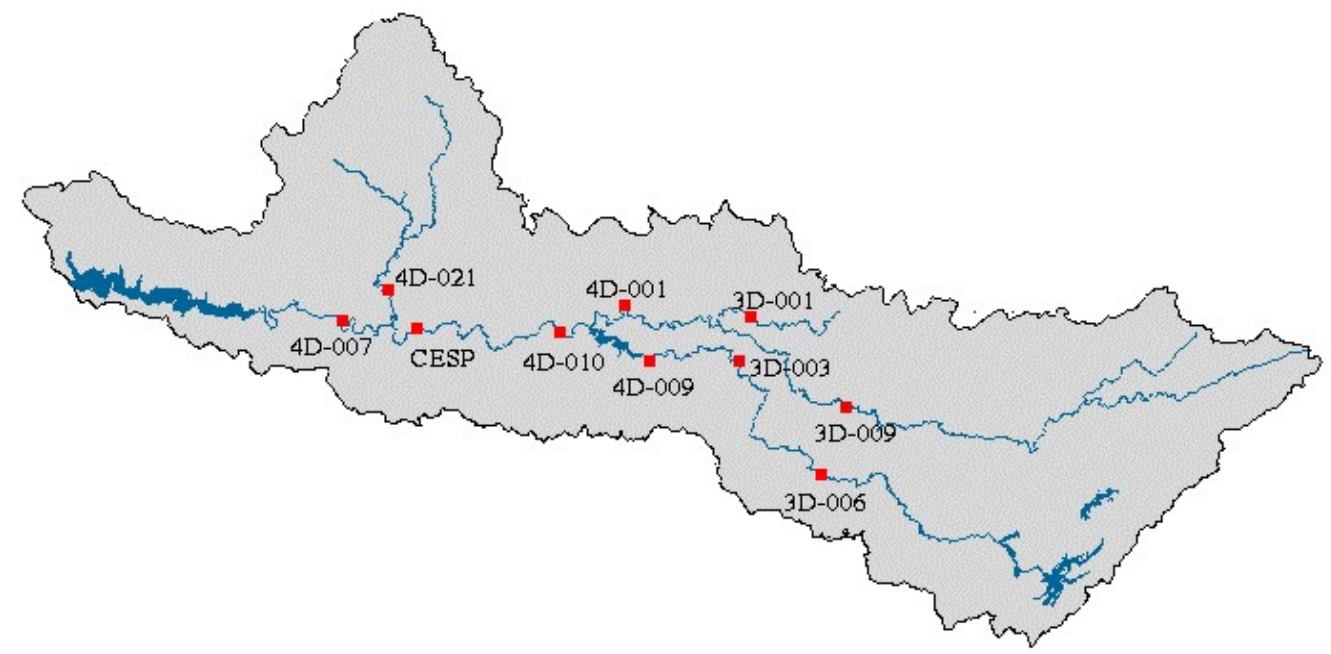

Figura 4.7 - Postos fluviométricos bacia do Piracicaba (Fonte: Azambuja, 2000)

Após a simulação, observou-se que é difícil suprir integralmente as demandas estimadas pela Secretaria do Meio Ambiente para o ano 2010 e manter as vazões mínimas estabelecidas nos diversos trechos do corpo d'água, implicando no estabelecimento de prioridades àquelas demandas mais nobres como forma de gerenciamento dos recursos disponíveis. Especificamente, quanto à sub-bacia do rio Atibaia, concluiu-se que o compartimento ambiental Pinheiros/Anhumas (C.PAN) demanda mais água para os diversos usos do que a água nele produzida, indicando elevada utilização dos recursos hídricos superficiais e alto índice de reutilização da água, com conseqüente escassez. 


\section{Modelo de Cobrança Proposto}

Ao ser analisado o item (4.1), constata-se a afirmação feita no item da revisão da literatura sobre a gestão de recursos hídricos de que Souza (1995), pensando a gestão dos recursos hídricos de maneira integrada e tendo como referência a sustentabilidade do meio, propõe um modelo de cobrança associando os valores da tarifa pelo uso da água aos padrões de qualidade e de emissão, visando ao melhor diálogo entre estes instrumentos.

No mesmo item da revisão, foi colocado sobre certa fragilidade na aplicação do licenciamento ambiental de atividades potencialmente poluidoras que utilizam recurso hídrico como insumo ou como receptor de resíduos, já que é permitido o exercício da atividade se o padrão de emissão for obedecido e se a atividade de forma isolada não comprometer a qualidade do recurso dada pelo padrão de qualidade.

Continuando, ponderou-se acerca da vocação da outorga de direito de uso de recursos hídricos em impor limites de utilização da água em função de padrões estabelecidos. Porém, negar o uso do recurso natural para determinada atividade que apresenta a mesma condição de outra já contemplada com esse mesmo recurso é como restringir o caráter de bem comum da água. Mudar uma condição assim posta, mesmo considerando a temporalidade e a transparência de critérios de outorga, requer um grande esforço dos envolvidos, além de eficácia temporária, visto que o recurso deverá ficar novamente escasso quando atingido novo patamar de exploração.

Considerando essa argumentação, o presente trabalho pretende contribuir efetivamente com a implementação da cobrança como instrumento econômico de gestão dos recursos hídricos apresentando um modelo baseado na metodologia proposta por Souza (1995), com modificações visando à eficácia na consecução de seus objetivos e à aplicabilidade frente à diversidade de fatores e agentes envolvidos. 
Assim como a metodologia citada, o modelo proposto contempla a cobrança sobre o uso dos recursos hídricos de corpos d'água superficiais relativa ao lançamento de efluentes e sobre a captação de água. No caso dos efluentes, considera-se a água utilizada para diluição, assimilação ou transporte de poluentes. Como volume de água captada que deve ser cobrado é considerada apenas a quantia retirada que não retorna ao corpo d'água, ou seja, cujo uso é consuntivo.

Em ambos os casos, o valor da tarifa a ser cobrada de cada usuário é definido simplesmente multiplicando-se o volume consumido pelo preço "unitário" de água, que é um preço por unidade de volume, e por um multiplicador, definido pelo Comitê de Bacia, que onere ou diminua o valor cobrado em função de aspectos prioritários do Plano de Recursos Hídricos, tais como: racionalização do uso da água, condições econômicas e sociais específicas e localização do usuário na bacia. Assim, o valor a ser pago segundo o modelo proposto será:

$$
T=K x U x V_{c o n}
$$

sendo: T o valor da tarifa a ser cobrada do usuário;

$\mathrm{K}$ o preço por unidade de volume;

U o multiplicador definido pelo órgão gestor;

$\mathrm{V}_{\text {con }} \mathrm{O}$ volume consumido.

O valor da tarifa (T) é relativo ao uso e não ao usuário. Assim sendo, se um mesmo usuário for responsável por diversos tipos de uso, como captar água e lançar mais de um poluente ao mesmo tempo, o valor total da cobrança será igual à soma das tarifas relativas a cada uso.

Desenvolvendo cada um dos fatores componentes da fórmula de cobrança, e observando-se as considerações iniciais, deve-se notar que o volume consumido pode ser tanto relativo à vazão captada quanto à vazão equivalente de utilização para lançamento de efluentes. Desta maneira, tanto para o corpo d'água receber determinados poluentes quanto para o uso de sua água bruta, existe uma vazão que pode ser considerada como efetivamente consumida $\left(\mathrm{Q}_{\mathrm{con}}\right)$, que no modelo, ao ser considerada ao longo do tempo de referência da cobrança, é responsável por " $\mathrm{V}_{\text {con" }}$ "

\footnotetext{
* As unidades relativas às variáveis do modelo não são especificadas a priori, deixando essa definição para quando de sua aplicação. Ex.: concentrações em $(\mathrm{mg} / \mathrm{l})$ ou $\left(\mathrm{kg} / \mathrm{m}^{3}\right)$; vazões em $\left(\mathrm{m}^{3} / \mathrm{s}\right)$ ou $(1 / \mathrm{s})$; valores monetários em (US\$) ou (R\$) etc.
} 
Por exemplo, durante um mês, se determinado usuário consumisse " $0,01 \mathrm{~m}^{3} / \mathrm{s}$ ", o volume a ser cobrado seria de " $25.920 \mathrm{~m}^{3}$ ".

A determinação da vazão consumida para o caso de captação é direta. Já para diluição, transporte ou assimilação de poluentes, a definição dessa vazão pode ser feita determinando-se a quantidade de água necessária para receber a carga poluidora do efluente sem que a concentração de poluente no corpo receptor exceda os limites dados pela legislação - padrão de qualidade. Mesmo com essas diferenças, a adoção da cobrança proporcional à vazão consumida possibilita a igualdade na fórmula da tarifa tanto para captação quanto para lançamento de poluentes, diferentemente da metodologia base, que usava uma fórmula distinta para cada caso. Essa mudança faz com que o modelo de cobrança proposto possibilite cobrar do usuário o mesmo valor quando este retira uma quantidade de água do corpo hídrico ou quando este polui essa mesma quantidade.

A proposta para a cobrança do presente trabalho modifica a metodologia base visando à sua efetiva implementação. Assim, com esse objetivo, houve a simplificação da fórmula da tarifa ao ser mantido o multiplicador definido pelo órgão gestor (U) e deixando-se de ponderar a razão entre a concentração remanescente do poluente encontrada no efluente e a concentração máxima permitida pelo padrão de emissão.

Ao final deste tópico, são abordadas algumas hipóteses sobre o multiplicador "U”, mediante as quais será observado que essa ponderação do sistema de tratamento pode ser facilmente contemplada. Além disso, também será observada outra diferença em relação à metodologia base, visto que, a princípio, este multiplicador não precisa ser diferente para o caso de poluição e de captação. Como já mencionado, esse multiplicador é determinado em função de valores da sociedade e objetivos refletidos pelos Comitês de Bacia, o que o torna o fator mais "subjetivo" do modelo de cobrança.

Outra modificação, esta de caráter conceitual, é o fato de a cobrança ser proporcional à vazão consumida e não à carga lançada. Para o modelo proposto, considera-se que o preço pago pelo lançamento de uma determinada quantidade de poluente não pode ser o mesmo de quando esta quantidade é lançada em corpos 
d'água cujas metas de qualidade sejam diferentes. Logo, lançar uma carga de poluição em um corpo d'água deve ficar mais caro quanto maior for o nível de qualidade da água necessário para atender à comunidade. Na metodologia base, é possível ocorrer uma situação de igualdade matemática entre os fatores ponderados nas tarifas dos usuários, fazendo com que a carga de poluente lançada defina a diferença entre os valores a serem pagos independente da poluição relativa provocada.

Finalmente, concluindo o detalhamento da fórmula de tarifa (5.1), algumas modificações também foram feitas na maneira de obtenção do preço " $K$ ". Originalmente, esse preço por volume não pode ser considerado um "preço unitário", pois se trata de um multiplicador com unidade dada em “(US\$.s)/(1.ano)". Além disso, sua definição só contempla situações nas quais o trecho considerado do corpo d'água possui lançamento de poluentes, ou seja, a metodologia base não pode ser aplicada, por exemplo, em um cenário onde só ocorra captação.

Outra limitação da definição original de "K" é que seu valor apenas está relacionado à perda de qualidade em função do excesso de poluição. A fórmula de valoração da água não prevê os casos em que a sustentabilidade do meio possa estar sendo comprometida à medida que a quantidade de água não é mais suficiente para dar suporte ao ecossistema. Na metodologia base, a própria cobrança sobre o uso que capta água só é proporcional às cargas de poluentes lançadas a montante do local de retirada de água, sem prever a possibilidade de as retiradas de montante já terem levado o corpo d'água a uma vazão mínima.

Como conseqüência dessa "falha" metodológica, ampliou-se a maneira de obtenção do preço por unidade de vazão, o qual constitui a espinha dorsal de qualquer modelo de cobrança e, neste modelo em específico, possui algumas diferenças relativas aos usos dos recursos hídricos para lançamento de poluentes e para a captação de água. Assim, a partir deste instante, o desenvolvimento do modelo terá dois momentos distintos: inicialmente, será apresentada a determinação do preço unitário "K" relativo ao lançamento de poluentes para, em seguida, ser abordado o caso de captação. 


\subsection{Cobrança sobre Lançamento de Poluentes}

Matematicamente, a carga de poluente de um efluente é dada multiplicando-se sua vazão pela concentração do poluente em questão - conforme expressão (5.2) - e a vazão equivalente utilizada para o lançamento de poluentes, que para o modelo é simplesmente vazão consumida, é dada pela expressão (5.3):

$$
C_{e}=Q_{e} x c_{e}
$$

sendo: $\mathrm{C}_{\mathrm{e}}$ a carga de poluente;

$\mathrm{Q}_{\mathrm{e}}$ a vazão do efluente;

$c_{e}$ a concentração de poluente.

$$
Q_{\text {con }}=C_{e} / c_{p q}
$$

sendo: $Q_{\text {con }}$ a vazão consumida;

$\mathrm{c}_{\mathrm{pq}}$ o padrão de qualidade.

O próximo passo é definir a carga de poluente a partir da qual não existem condições de assimilação pelo corpo receptor sem comprometer a qualidade desejada, ou seja, a carga que leva o meio ao estado de saturação. Essa definição é feita baseada no limite de concentração de determinado poluente permitido no corpo d'água (padrão de qualidade) e na vazão de referência do mesmo corpo d'água destinada à diluição e à depuração. Com base nesses fatores, é definida a carga de saturação do corpo d'água referente ao poluente, dada pela expressão (5.4):

$$
\begin{array}{r}
C_{s}=Q_{r} x c_{p q} \\
\text { sendo: } \mathrm{C}_{\mathrm{s}} \text { a carga de saturação; } \\
\mathrm{Q}_{\mathrm{r}} \text { a vazão de referência. }
\end{array}
$$

A vazão de referência pode ser determinada utilizando-se modelo de simulação matemática e deve ser definida mediante critérios discutidos pelo Comitê de Bacia, sabendo-se que quanto maior a garantia da existência de água menor o valor da vazão de referência e, por conseqüência, mais fácil será alcançada a saturação do corpo d'água. Têm-se como exemplos dessas vazões de referência valores como "Q ${ }_{90}$ " e "Qméd", além da possibilidade de utilização de outros valores cujas determinações são bastante facilitadas pela simulação matemática*

\footnotetext{
* Por exemplo, em função de riscos ambientais, podem ser adotadas vazões mais conservadoras como "Q ${ }_{90}$ ", vazão que ocorre em pelo menos $90 \%$ do período analisado, ou, em situações menos críticas, vazões maiores próximas à vazão média $\left(\mathrm{Q}_{\text {méd }}\right)$.
} 
Nesta vazão de referência reside uma das diferenças do modelo proposto em relação à metodologia base. Apesar de ambas as fórmulas de cobrança apresentarem esta vazão como sendo a mínima destinada ao lançamento de poluentes, na aplicação da metodologia base, foi adotada " $\mathrm{Q}_{7,10}$ " como sendo sempre a referência do valor cobrado, o que pode ser considerado extremamente conservador. Considera-se mais adequado a adoção de vazões de referência como proposto neste trabalho, o que, além de permitir contemplar os objetivos dos Planos de Recursos Hídricos, possibilitará contemplar a disponibilidade sazonal de água já na origem da formação de seu preço, tornando-o mais justo e eficiente.

Como apontado anteriormente, quando efetuado o lançamento do efluente para diluição, transporte e assimilação de determinados poluentes, existe uma vazão equivalente de utilização de água, que, assim como para a captação, também pode ser considerada como consumida $\left(\mathrm{Q}_{\text {con }}\right)$. Tomando-se o parâmetro que esteja sendo analisado (que pode ou não ser aquele que implica a maior vazão equivalente consumida), pode-se fazer o cálculo da parcela da carga de saturação que ainda pode ser assimilada pelo corpo receptor após o lançamento. Essa parcela, denominada carga disponível, é calculada conforme a expressão (5.5):

$$
C=\left(Q_{r}-Q_{c o n}\right) x c_{p q}
$$

sendo: C a carga disponível após o uso.

Para que sejam considerados os valores do padrão de qualidade da água no trecho analisado, relativo a determinado poluente, e todos os efluentes lançados a montante com concentrações desse mesmo poluente - com estes devendo obedecer ao padrão de emissão - é definido um índice de qualidade associado à carga disponível no corpo d'água, dado pela equação a seguir:

$$
I=\frac{C-\sum C_{e}}{C_{s}}
$$

sendo: I o índice de qualidade;

$\sum \mathrm{C}_{\mathrm{e}} \mathrm{o}$ somatório das cargas de montante.

No cálculo do índice de qualidade (I), mais uma diferença é observada entre o modelo de cobrança proposto e a metodologia base. Nesta nova proposta, para o cálculo do índice (I) no trecho analisado, a carga disponível (C) é ponderada no lugar 
da carga de saturação $\left(\mathrm{C}_{\mathrm{s}}\right)$, garantindo a aplicação do princípio de ponderar-se a “diminuição" da vazão de diluição no valor cobrado. Observa-se, então, uma vantagem da fórmula proposta sobre a metodologia base, visto que nela a tarifa cobrada ao usuário já reflete o impacto causado por sua atividade.

Analisando-se ainda o índice de qualidade, quando o poluente não for conservativo, o somatório " $\sum \mathrm{C}_{\mathrm{e}}$ " deve refletir a diminuição das cargas ao longo do trecho compreendido entre seus locais de origem e o ponto do lançamento avaliado para a cobrança. Para estes casos, e tendo como exemplo mais comum de poluente não conservativo a demanda bioquímica de oxigênio (DBO), existe a possibilidade do cálculo da diminuição da carga poluidora baseado na fórmula de Streeter-Phelps* .

O índice de qualidade, ao exprimir o comprometimento ambiental do corpo d'água, observa diversos aspectos necessários quando se pretende definir o valor a ser cobrado pelo uso da água, a saber:

- disponibilidade hídrica: dada pela vazão de referência obtida do modelo matemático;

- confiabilidade quanto à real disponibilidade do recurso: também associada à vazão obtida através do modelo de simulação matemática, que é função das prioridades definidas pelo comitê da bacia;

- classe em que está enquadrado o corpo de água receptor: expresso no índice por " $\mathrm{C}_{\mathrm{s}}$ “" (na qual está implícito “ $\mathrm{c}_{\mathrm{pq}}$ ");

- carga de lançamento: expressa por " $\mathrm{C}_{\mathrm{e}}$ " e relacionada diretamente com " $\mathrm{Q}_{\text {con }}$ ";

- sazonalidade: expressa pelas vazões de referência e considerada em períodos tão variáveis quanto o comitê definir (ou também, quando utilizados, em função de limitações de modelos matemáticos);

- vazões que passam a ser indisponíveis em função do lançamento: expressas por "C" (na qual está implícita " $\mathrm{Q}_{\text {con }}$ ) e também consideradas ao utilizar-se " $\Sigma \mathrm{C}$ e".

Novamente, cabe ressaltar que o índice de qualidade reflete a real possibilidade de uso da água ao relacionar o padrão de qualidade desejado para o recurso hídrico à totalidade das cargas poluidoras lançadas no corpo d'água considerado. Esse dado é fundamental quando se pretende trabalhar com o conceito de sustentabilidade.

\footnotetext{
* A fórmula de Streeter-Phelps foi desenvolvida em 1925 e desde então vem servindo de embasamento aos modelos de autodepuração de rios, os quais são largamente aplicados e aceitos mesmo frente à quantidade reduzida de dados hidrológicos.
} 
O próximo passo é relacionar esse grau de comprometimento do corpo d'água ao preço da água. Inicialmente, determina-se que quanto menor "I" - o que indica maior comprometimento - maior o preço do recurso hídrico. Esta lógica incentiva a redução efetiva da contaminação hídrica visto que, mesmo um usuário diminuindo sua carga lançada, o aumento do índice só estará assegurado se o conjunto das cargas lançadas diminuírem. Além disso, para o índice de qualidade igual a "um" $(\mathrm{I}=1)$ existe a ausência de lançamento, ou seja, o valor a ser cobrado será zero. De outro lado, quando o índice aproxima-se do valor zero, o que indica a saturação do corpo d'água para o uso pretendido, deve-se ter um aumento mais expressivo do preço. Assim, o usuário terá seus custos aumentados rapidamente quanto mais próximo da saturação estiver o corpo d'água.

A lógica exposta é a base para a construção da curva para cobrança apresentada na figura (5.1) - e é seguida pelo modelo proposto conforme definida na metodologia base. A partir deste ponto, a construção da curva proposta segue lógica diferente da apresentada em Souza (1995), a qual associa a qualidade da água ao custo médio de sistemas de tratamento de efluentes. $\mathrm{O}$ autor acredita que, através desta associação, o valor monetário fornecido pela curva induzirá o poluidor-pagador a utilizar água de maneira a obedecer ao padrão desejado.

Visando à eficácia na consecução desse objetivo, no presente trabalho, propõe-se substituir o custo de tratamento por uma curva associada à capacidade de o usuário pagar pelo recurso hídrico. Se o objetivo é evitar que o agente econômico pague e continue poluindo além do limite desejado, nada mais efetivo do que associar essa poluição ao quanto ele não consegue pagar. Além disso, como garantir que uma valoração baseada no custo de tecnologias de correção da poluição consiga prevenir eficientemente a produção dessa poluição? Uma valoração ambiental que vise à sustentabilidade do meio não deve fundamentar-se na crença de que a escala econômica evitará a saturação que se dá na escala ambiental. 
Portanto, chegando-se a essa saturação $(\mathrm{I}=0)$, o usuário deverá estar sendo cobrado no limite da sua capacidade de pagamento ${ }^{*}$, que pode ser avaliada para o segmento da atividade a qual pertence, para alguma subdivisão desse segmento ou para uma atividade específica. A partir desse ponto já existe o comprometimento da qualidade da água $(\mathrm{I}<0)$ e deve haver grande apelo financeiro para a diminuição efetiva da poluição. Na formulação, este apelo financeiro é traduzido numericamente dobrando-se o valor a ser pago quando superados aproximadamente $30 \%$ da saturação, que, a princípio, acredita-se ser uma boa medida da capacidade de recuperação do meio. Matematicamente, é possível definir outro nível de comprometimento dos recursos hídricos que mantenha o caráter exponencial da curva, esse sim fundamental à consecução dos objetivos do modelo de cobrança proposto.

Desta maneira, define-se um preço por unidade de volume $(\mathrm{K})$, que pode ser cobrado a cada período de tempo definido pelo comitê (ex.: mensal ou anual), cuja curva associada ao índice de qualidade tem o comportamento ilustrado pela figura (5.1) e é obtida através da equação (5.7):

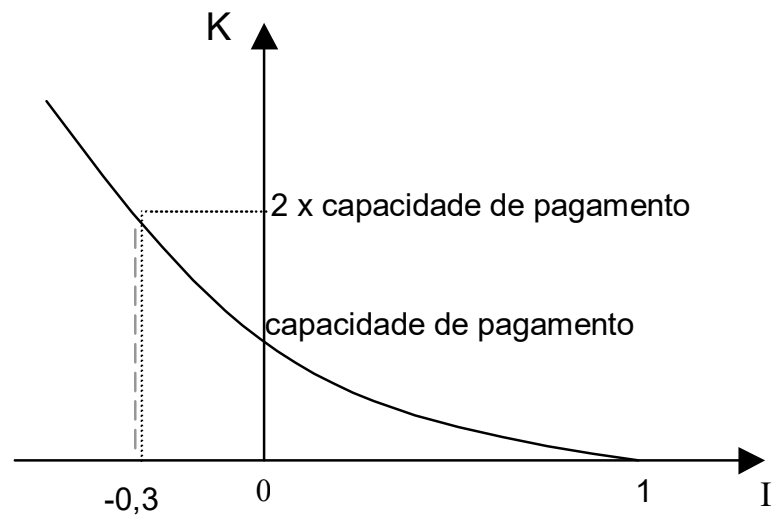

Figura 5.1 - Curva para cobrança

$$
K=\operatorname{CAPx}(1-I)^{2.65}
$$

sendo: CAP o valor da capacidade de pagamento.

\footnotetext{
* Como visto no item (4.2), segundo Righetto (2001), existem várias formas para se obter a capacidade de pagamento de um agente econômico frente ao aumento de custo de sua atividade. Para o modelo, o importante é a possibilidade desta capacidade fornecer a referência financeira que favorece ou até inviabiliza o uso do recurso hídrico em função de seu preço.
} 
A capacidade de pagamento deve ser aplicada ao período cobrado (mensal, anual etc.) e, para existir uma coerência dimensional no modelo, é necessário que seja uma grandeza monetária por unidade de volume. Como muitas vezes a capacidade de pagamento de um agente econômico é dada para determinado período de tempo diferente do período cobrado, para o ajuste matemático, basta considerar o volume de água consumido pela atividade nesse período de referência. Da mesma maneira, se para o caso de irrigação a capacidade for dada em função da área plantada, determina-se o consumo de água por unidade de área relativo ao período cobrado e procede-se à adequação de "CAP".

Isto tudo é colocado a fim de se compatibilizar o montante arrecadado à capacidade de pagamento das diferentes categorias de atividades, fazendo com que o uso seja sustentável ambientalmente ou o usuário tenha dificuldades quanto aos seus custos de produção. Na prática, o que se pretende é utilizar a capacidade de pagamento como sendo a "capacidade de não-pagamento" pelo uso que levaria o recurso hídrico a níveis de escassez superiores ao limite ambiental desejado pela sociedade.

Além disso, pode-se fazer uma análise em termos de eficiência ambiental e econômica mediante a associação entre capacidade de pagamento máxima e qualidade ambiental desejada mínima. No contexto do modelo de cobrança proposto, quando atingido esse ponto limite, o preço da água induzirá à diminuição da demanda e existirá a melhora gradativa da qualidade ambiental. Com o aumento da oferta de recurso haverá a conseqüente diminuição da tarifa, o que levará ao aumento do uso da água até o limite ambiental associado à capacidade de pagamento máxima. A situação se repetirá até ser atingido o equilíbrio, quando, então, os recursos estarão sendo usados no limite desejado pela sociedade e estarão contribuindo com a produção de bens, geração de renda e justiça social. O caráter social é dado em função do máximo arrecadado pela gestão pública ao mesmo tempo em que são preservados os agentes privados cujas atividades estejam de acordo com os valores ambientais da sociedade.

Outro caráter de justiça social e econômica pode ser dado se for assumida a capacidade de pagamento como o máximo que o usuário está disposto a pagar - ou 
disposição a pagar - a fim de ser mantido um mínimo de qualidade. Nesse caso, se a sociedade, incluso o usuário, tem como valor a qualidade ambiental, é razoável imaginar que existe a disposição de pagamento por um mínimo de qualidade e, no limite, essa disposição será concretizada de acordo com o máximo da capacidade de pagamento.

Concluindo, a essência da construção da curva para a cobrança é associar a qualidade da água à capacidade do usuário não pagar pelo uso excessivo dos recursos hídricos. Para tanto, a determinação do preço por quantidade de água considera diversos aspectos necessários à valoração, sendo que vários deles já foram listados quando analisado o índice de qualidade - em função da relação "preço x índice de qualidade". Outros aspectos ficaram explícitos no desenvolvimento da construção da curva para cobrança, mas, sendo esses fatores fundamentais ao modelo proposto, cabe aqui listá-los juntamente a novas considerações:

- natureza da atividade: contemplada ao se utilizar diferentes capacidades de pagamento para os diferentes segmentos de usuários;

- redução da poluição hídrica: nada mais efetivo para a redução da poluição do que a atividade geradora dessa poluição poder ser inviabilizada por esta, fato levado a cabo na associação entre a capacidade de pagamento e o ponto de degradação da qualidade da água;

- associação entre sustentabilidade ambiental e viabilização financeira: a possibilidade oferecida pelo modelo de simulação de uma vazão de referência com garantias estatísticas de ocorrência, além do viés da sustentabilidade ambiental dado ao índice de qualidade, possibilita ao sistema de cobrança uma maior arrecadação para melhoria da infra-estrutura responsável por essas vazões (quanto maior a garantia da existência de água $\rightarrow$ menor o valor do índice $\rightarrow$ maior o preço por unidade de água consumida).

\subsection{Cobrança sobre Captação de Água}

Resta definir o valor a ser cobrado de cada usuário para o caso da captação de água superficial. Para tanto, basta relembrar que a definição de " $\mathrm{Q}_{\text {con }}$ " para usos de recursos hídricos com captação não é mais uma vazão equivalente. Nestes casos, ela será a vazão efetivamente retirada, ou seja, toda vazão de captação ou a diferença entre a vazão captada e a devolvida ao corpo d'água, quando essa devolução existir. Sem considerar essa "diferença" entre as vazões, o desenvolvimento da cobrança sobre captação é exatamente o mesmo daquele já apresentado no item (5.1) quando o 
crítico para o ambiente é o aumento da concentração de poluente no trecho analisado em função da retirada de água.

De outra maneira, quando se diminui a vazão do corpo d'água, pode ser atingido um estado no qual a quantidade remanescente de água seja tal que represente uma condição mais crítica do que a concentração advinda do possível aumento da poluição. Para estes casos de vazão crítica, o modelo proposto possibilita que o uso com captação de água seja cobrado com base na simples diminuição da vazão - tendo como referência fórmula de índice de qualidade a ser apresentada no próximo tópico (qualidade $\mathrm{x}$ vazão mínima) - ao invés de baseado no aumento de poluição, cuja fórmula do índice de qualidade foi apresentada pela expressão (5.6).

Assim sendo, para que a cobrança sobre captação tenha seu valor associado à situação ambiental mais crítica, serão consideradas as captações em corpos d'água com qualidade comprometida pela presença de carga poluidora e em cenário cujo problema é manter a vazão acima de um valor mínimo, caso, por exemplo, de cenários livres de poluentes onde ocorra captações em excesso.

\subsubsection{Qualidade determinada pela Vazão Mínima}

A formulação apresentada para esta abordagem não encontra paralelo na metodologia base, mas, como ficará claro ao longo de seu desenvolvimento, também se inspira em toda formulação feita para lançamento de poluentes.

Quando a vazão do corpo d'água é preponderante no aumento da escassez dos recursos hídricos, ou quando não existem lançamentos de poluentes no corpo d'água considerado na análise da cobrança, a fórmula final continua a mesma dada pela expressão (5.1). Entretanto, a sustentabilidade do sistema passa a ter como referência a vazão efetivamente disponível, ou seja, cuja utilização não compromete irremediavelmente o ambiente.

Já dado pela legislação, " $\mathrm{Q}_{7,10}$ " é este parâmetro ambiental correspondente ao padrão de qualidade no cálculo da carga de saturação (apresentado pela expressão 5.4). Assim, subtraindo-se o valor de " $\mathrm{Q}_{7,10}$ " daquele da vazão de referência dado pelo modelo de simulação matemática tem-se uma "vazão ambiental" que, por 
coerência do modelo, será denominada vazão de saturação e é calculada conforme expressão (5.8):

$$
Q_{s}=Q_{r}-Q_{7,10}
$$

sendo: $\mathrm{Q}_{\mathrm{s}}$ a vazão de saturação;

$\mathrm{Q}_{\mathrm{r}}$ a vazão de referência.

Também por uma questão de coerência, define-se uma vazão disponível obtida segundo a expressão (5.9) - equivalente à carga dada pela expressão (5.5):

$$
Q=Q_{s}-Q_{c o n}
$$

sendo: $Q_{\text {con }}$ a vazão consumida;

Q a vazão disponível.

O índice de qualidade, que agora passa a ser um índice que reflete a qualidade relacionada apenas a uma vazão mínima, é dado pela expressão (5.10) e, apesar da "saturação do meio" ocorrer apenas em períodos de seca ou mediante retirada excessiva de água, valem as mesmas considerações feitas para a escassez de água em função da perda de qualidade relacionada a uma carga de poluente excessiva.

$$
I=\frac{Q-\Sigma Q_{c o n}}{Q_{s}}
$$

sendo: $\sum \mathrm{Q}_{\text {con }}$ o somatório das captações de montante.

Para que haja coerência matemática, é importante que "Q" zero. Portanto, a vazão de referência deverá ser sempre maior que "Q $\mathrm{Q}_{7,10}$ ”, o que também mantém relação de coerência entre o índice de qualidade e a realidade que ele pretende exprimir. Se a saturação de referência se apresenta de tal modo que não se observa nem mesmo uma vazão ambiental mínima, medidas de controle mais extremas são necessárias e mesmo a cobrança pode obedecer a um regime especial.

\subsubsection{Qualidade determinada pela Poluição}

Para o desenvolvimento do modelo considerando a saturação com aumento de poluição em função da captação de água, deve ser considerado o poluente cuja concentração seja a mais crítica, medida fundamental na busca da sustentabilidade do recurso hídrico e que já é prevista pela metodologia base. Assim, no cálculo do índice de qualidade, é feito o somatório de todas as cargas relativas a esse parâmetro 
crítico, o qual também deve ser a referência do padrão de qualidade. Isso faz com que o índice de qualidade exprima o comprometimento da qualidade da água relativo ao poluente que mais está afetando a capacidade de depuração e diluição do corpo d'água.

Como no modelo proposto a cobrança é sempre proporcional à vazão consumida, quando a situação crítica for dada pela existência de poluição e não pela proximidade de um valor mínimo de vazão, o usuário que subtrai determinada quantidade de água paga o mesmo valor daquele poluidor que utiliza a mesma quantidade equivalente de água para lançar um efluente contendo o parâmetro que apresenta a situação mais crítica quanto à saturação. Em termos de sustentabilidade ambiental, nada mais justo.

\subsubsection{Análise comparativa da qualidade: Vazão Mínima x Poluição}

A cobrança sobre a captação de água em cenários com carga poluidora pode ser função tanto da diminuição da vazão a patamares muito baixos quanto da falta de água para a diluição e depuração de poluentes. Nesses cenários, os recursos hídricos podem ser utilizados tanto para o lançamento de poluentes quanto para a captação de água e a situação crítica para o ambiente poderá ser dada tanto pela concentração excessiva de determinado poluente quanto pela vazão de água disponível. Logo, comparando-se o índice de qualidade para as duas situações poderá ser definida qual formulação é a mais adequada para a cobrança sobre a captação, se aquela referente à poluição ou à vazão mínima.

Para saber quando o valor de "I" será menor, o que denota maior comprometimento das condições ambientais, pode-se usar exatamente as mesmas fórmulas que levam às expressões (5.6) e (5.10), bastando lembrar que, para o uso do índice referente à poluição, além de " $Q_{\text {con }}$ " não ser mais uma vazão equivalente, o cálculo das cargas disponível e de saturação devem ser efetuados para o poluente cuja concentração seja a mais crítica. No fim da análise, deverá prevalecer o maior preço por vazão captada, correspondente ao fator mais danoso ao meio ambiente. 
Depois de analisadas as situações para a cobrança sobre o uso da água superficial, observa-se que o modelo tem como resposta sempre a mesma fórmula simples que, além da fácil compreensão do que está sendo cobrado, deixa claro os princípios de sua concepção, ou seja, cobrar mais quanto maior a escassez de água e fazer com que o valor cobrado leve o usuário a considerar a sustentabilidade ambiental. A figura (5.2) permite a visualização de toda estrutura da proposta de cobrança sobre o uso de recursos hídricos.

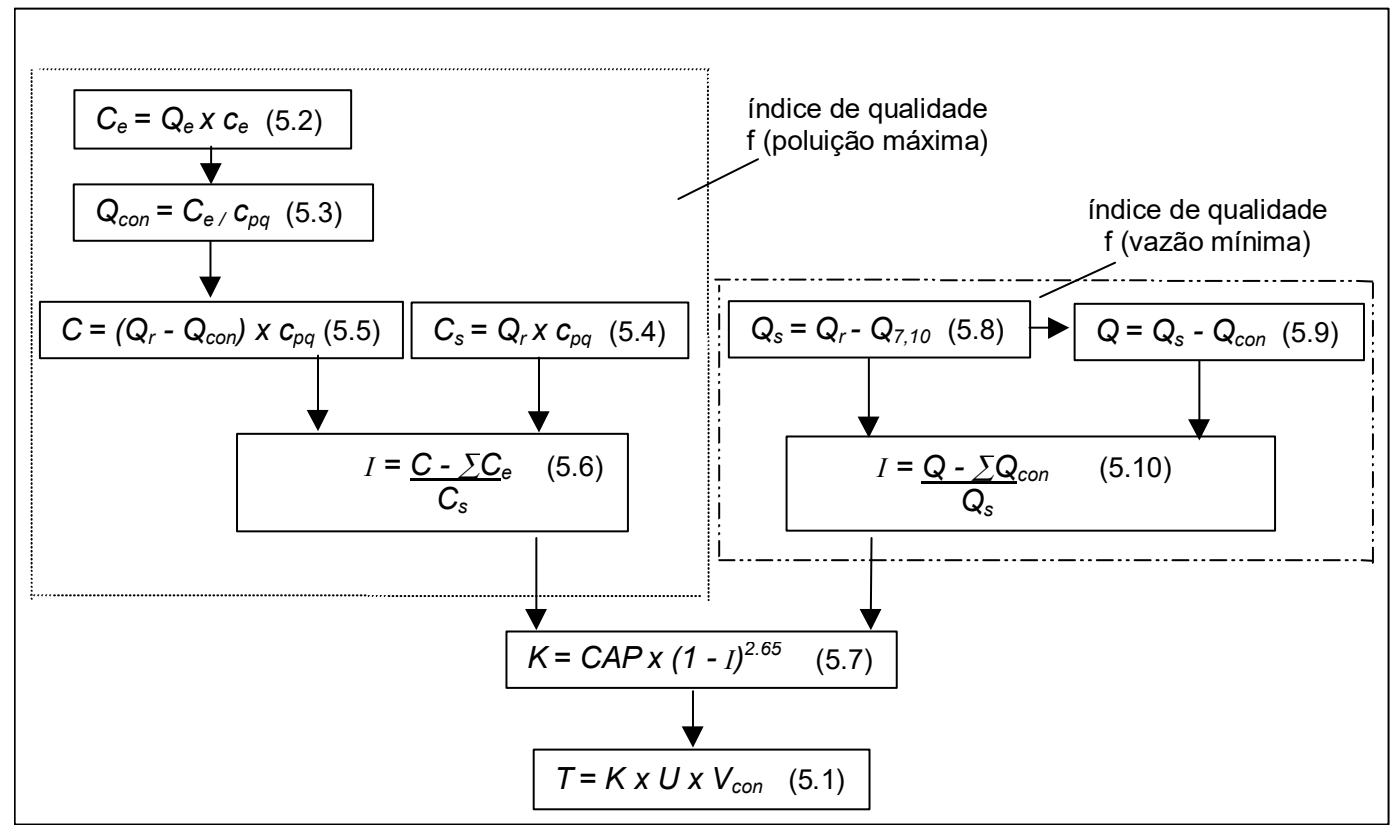

Figura 5.2 - Formulação do modelo de cobrança proposto

Algo mais complexo quanto a questões econômicas e sociais deverão ser amplamente discutidas pelos comitês quando definidos os valores cobrados, em especial, o valor do multiplicador "U”. Neste caso, diversas possibilidades podem ser contempladas numericamente, por exemplo: determinado segmento de usuários pode ser dividido em classes, considerando fatores econômico-financeiros ou sociais, e determinada classe pode ter o valor cobrado aumentado na mesma proporção que outra terá este diminuído, mantendo-se o total arrecadado. Da mesma maneira, essa lógica pode ser aplicada entre segmentos de usuários.

Também pode ser definida a indução de ocupação de determinada localidade por um segmento específico de usuários, os quais teriam desconto nos valores cobrados ao utilizarem o recurso hídrico desse local escolhido. O contrário também poderia ser feito, cobrando mais de usuários localizados junto a corpos d'água cuja 
utilização pretendida pela sociedade seja outra. Outra possibilidade é diminuir o valor cobrado à medida que o usuário melhore a eficiência do sistema de tratamento do efluente. Como já mencionado, esse caso foi contemplado por Souza (1995), que inclui na fórmula da tarifa um multiplicador igual ao quociente da divisão entre a concentração de poluente no efluente e a concentração definida pela resolução CONAMA 20/86. Nada impede que este quociente, ou outro redutor de tarifa associado a formas consideradas mais eficientes de uso da água, esteja embutido em "U”.

Independente de argumentos dessa natureza, como resultado final do modelo, tem-se simplesmente a multiplicação de um valor unitário de água pelo volume consumido, cujo resultado pode ser aumentado ou diminuído pelos Comitês de Bacia em função dos objetivos contidos nos Planos de Recursos Hídricos: "K x U x V". 


\section{Aplicação do Modelo: Resultados e Discussão}

Para que seja observada a possibilidade de aplicação do modelo de cobrança proposto frente à realidade de informações existentes, alguns exemplos de valores cobrados são apresentados utilizando-se dados da bacia hidrográfica do rio Atibaia, constituinte da bacia do rio Piracicaba, localizada no Estado de São Paulo. Esta aplicação é base de várias considerações acerca do modelo, ajudando a alcançar os objetivos propostos e, mesmo limitada aos cenários simulados, deve evitar falsas generalizações ao manter-se fiel à metodologia estabelecida.

A área foi escolhida levando-se em consideração a disponibilidade de dados, com qualidade compatíveis à finalidade do trabalho, e a condição da bacia do rio Atibaia, referência do desenvolvimento regional. Trata-se de região de grande desenvolvimento econômico com grandes atividades consumidoras de recursos hídricos, onde a industrialização intensa associada à presença de grandes centros urbanos e a uma agricultura moderna demanda água a ponto de gerar degradação de sua qualidade com conseqüente conflito por seu uso.

Esse cenário regional estimula a realização de vários estudos tanto por parte do governo quanto por parte de instituições de pesquisa. Os próprios trabalhos utilizados como subsídio à construção do modelo de cobrança proposto - Souza (1995), Righetto (2001) e Azambuja (2000) - se utilizam dessa região em seus estudos. Assim, a simulação de cobrança aqui apresentada será baseada em estudos já existentes e, mesmo sendo adotadas simplificações e adaptações às informações, seus resultados possibilitarão verificar a aplicabilidade e a coerência do modelo proposto. 


\subsection{Caracterização da Área de Estudo}

Antes da aplicação da metodologia de cobrança, procurou-se caracterizar a área de estudo frente aos seus componentes ambientais físicos e sócio-econômicos. A área compreende a bacia hidrográfica do rio Atibaia, apresenta uma área de drenagem de $2.770 \mathrm{~km}^{2}$ localizada no centro leste do estado de São Paulo, entre os paralelos $22^{\circ} 41^{\prime}$ e $23^{\circ} 18^{\prime}$ Sul e os meridianos $46^{\circ} 00^{\prime}$ e $47^{\circ} 16^{\prime}$ Oeste. A figura (6.1) representa esquematicamente a região onde se localiza a área de estudo, cujo limite segue o divisor da bacia.

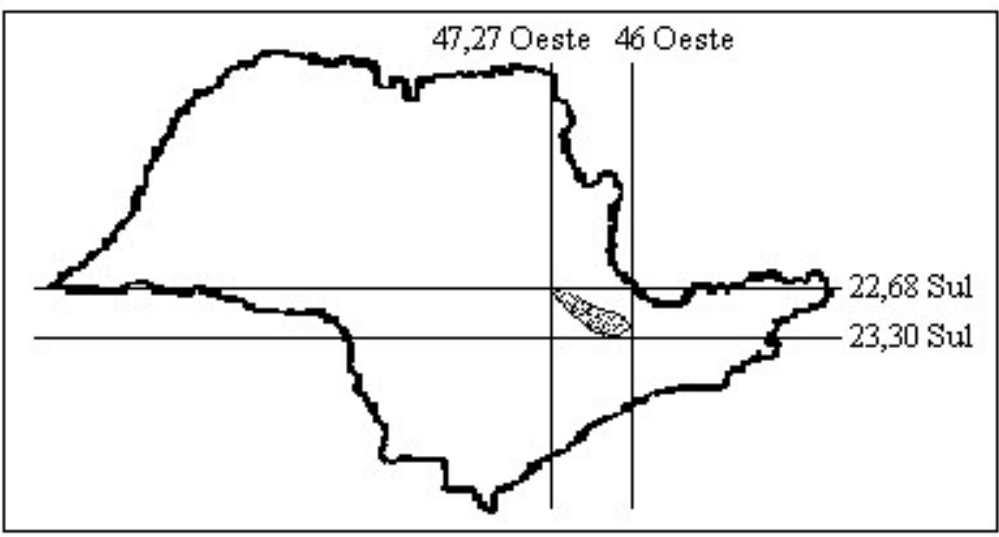

Figura 6.1 - Localização da área de estudo

A bacia do rio Atibaia, próximo à nascente, apresenta clima temperado brando sem estação seca, com verão suave, temperatura média anual de $18^{\circ} \mathrm{C}$ e valores de precipitação em torno de $1500 \mathrm{~mm} /$ ano. Nos trechos do médio e baixo Atibaia, o clima é temperado brando com inverno seco e verão quente, temperatura média anual de $20^{\circ} \mathrm{C}$ e valores de precipitação registrados de $1200 \mathrm{~mm} /$ ano. Pertencente à bacia, tem-se o reservatório de Salto Grande (Latitude Sul de $22^{\circ} 44^{\prime}$ e Longitude Oeste de $46^{\circ} 19^{\prime}$ ), represa cuja barragem está cerca de $850 \mathrm{~m}$ a montante da confluência com o rio Jaguari e cuja finalidade primordial é a geração de energia elétrica por meio da Usina Hidrelétrica de Americana, com capacidade de geração de $30 \mathrm{MW}$. 
Em conjunto com o rio Jaguari, o rio Atibaia é um dos principais formadores da bacia do rio Piracicaba, em cuja cabeceira localizam-se quatro dos cinco reservatórios do sistema Cantareira, responsável pelo abastecimento de mais da metade do suprimento de água para a cidade de São Paulo, contribuindo, segundo SMA (1994), com a vazão máxima de $31 \mathrm{~m}^{3} / \mathrm{s}$ - na figura (6.2) é apresentada a localização esquemática do sistema descrito. $\mathrm{O}$ rio Atibaia, portanto, pertence à bacia hidrográfica do rio Piracicaba, a qual forma a $5^{\text {a }}$ Unidade de Gerenciamento de Recursos Hídricos do Estado de São Paulo ( $5^{\text {a }}$ UGRHI) em conjunto com as bacias dos rios Capivari e Jundiaí.

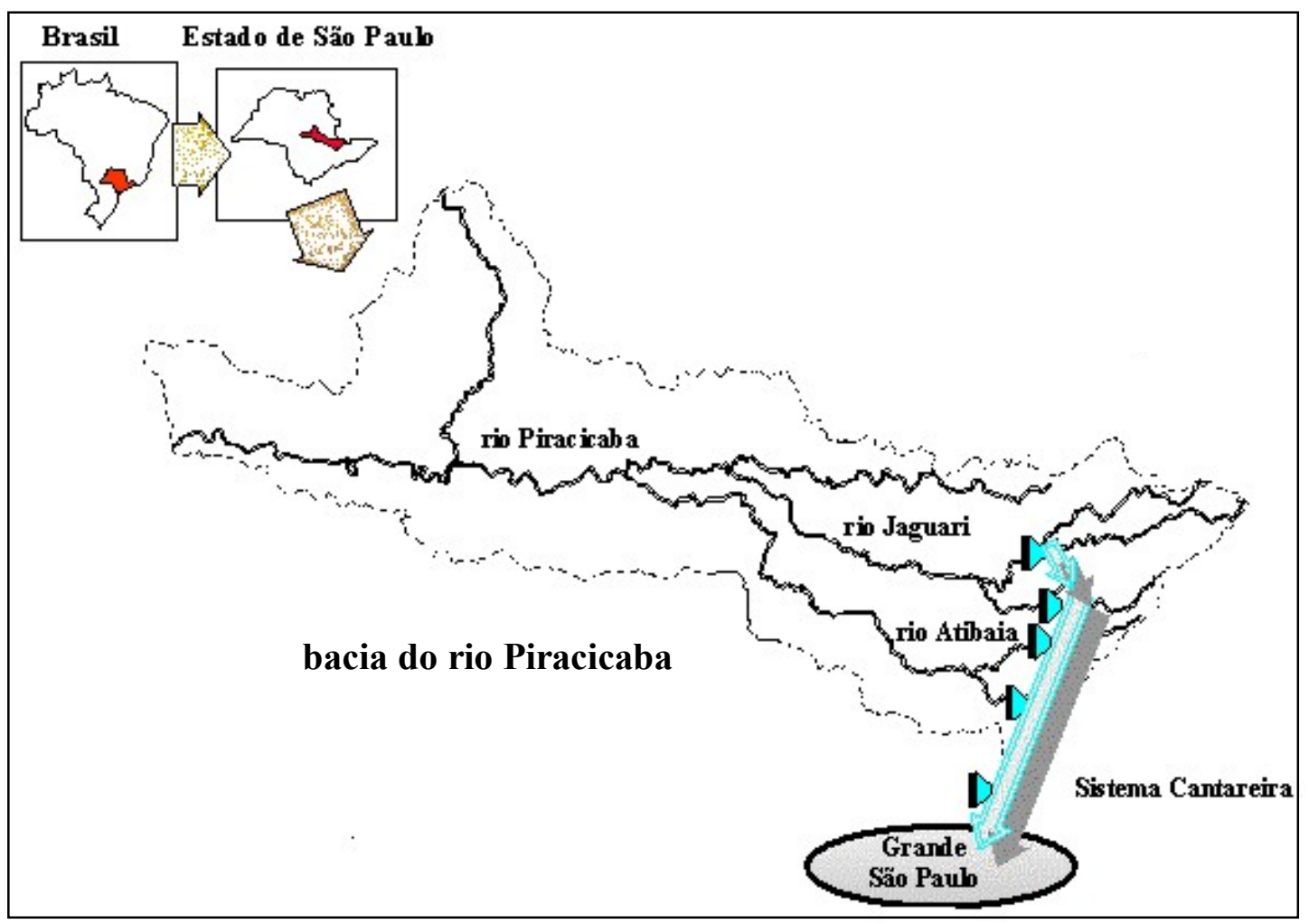

Figura 6.2 - Localização da bacia do rio Piracicaba

A derivação de $31 \mathrm{~m}^{3} / \mathrm{s}$ para São Paulo foi calculada de forma a manter uma vazão mínima de $15 \mathrm{~m}^{3} / \mathrm{s}$ em Paulínea e $40 \mathrm{~m}^{3} / \mathrm{s}$ na cidade de Piracicaba. Entretanto, aumentos significativos das demandas consuntivas na bacia do rio Piracicaba devido à expansão da agricultura irrigada, que já utiliza $6,1 \mathrm{~m}^{3} / \mathrm{s}$, e ao crescimento da área urbanizada, responsável atual pelo consumo de $4,5 \mathrm{~m}^{3} / \mathrm{s}$ para abastecimento urbano, tendem a tornar cada vez mais difícil manter essas vazões mínimas concomitantemente com a derivação do Sistema Cantareira (SMA, 1994). 
Analisando alguns indicadores sócio-econômicos deste cenário, destaca-se que a população da bacia do rio Atibaia está em torno de 900 mil habitantes, sendo a quase totalidade residente em zonas urbanizadas, o que a torna uma região de grande crescimento econômico. A bacia possui um dos mais importantes parques industriais do país $\left(3^{\circ}\right.$ pólo industrial do Brasil), sendo os principais tipos de indústrias o químico, o petroquímico, o têxtil e o de papel e papelão. Sua malha urbana é densa e sua infra-estrutura é bem diversificada, com importantes estradas de rodagem, um aeroporto internacional e várias universidades .

A origem desse crescimento foi a política de desenvolvimento descentralizado adotada nos anos 70, responsável pelo deslocamento de atividades econômicas da região da capital para o interior do Estado. Assim, alguns municípios passaram a constituir pólos de atração de diversas atividades consumidoras e degradadoras dos recursos hídricos - especialmente Campinas, Americana e Paulínea - fazendo a relação "demanda / disponibilidade de água” na bacia do rio Atibaia tornar-se crítica. Segundo dados do Comitê de Bacia, no ano 2000, considerada a vazão $\mathrm{Q}_{7,10}$, a demanda nessa bacia atingiu 139,5\% das disponibilidades e, em relação à vazão $\mathrm{Q}_{95}$, a demanda atingiu $106 \%$ da oferta.

Além desses números da escassez de recursos hídricos, o estilo de desenvolvimento adotado na região é fonte de poluentes que diminuem a quantidade de oxigênio nos corpos d'água, já que estes recebem os efluentes domésticos e industriais. Isso se dá porque, apesar de a maioria da população ter acesso ao serviço de coleta de esgotos, as cidades não possuem sistemas de tratamento. O quadro é agravado considerando que a bacia serve de manancial de abastecimento para 16 municípios e sua ocupação também é responsável por uma grande quantidade de poluição difusa nos trechos que cortam cidades e áreas com culturas agrícolas.

A região sofreu uma modernização do setor agrícola, resultando no uso intensivo do solo com utilização de insumos químicos e mecanização do sistema produtivo. A área cultivada da bacia do Atibaia é $57 \%$ do total de $2.770 \mathrm{~km}^{2}$, com destaque para a pastagem de braquiária. As culturas mais encontradas são o milho, a cana-de-açúcar e a fruticultura de uva, abacate e laranja. Os reflorestamentos de essências não nativas são constituídos predominantemente por eucaliptos e pinus. 
Quanto à vegetação nativa, esta ocupa apenas $12 \%$ da bacia e é constituída por capoeiras, cerrados, vegetação de várzea e algumas matas densas.

A falta de vegetação nativa, principalmente matas ciliares, indica o quadro de degradação dos recursos naturais na região. Especificamente quanto aos corpos d'água, isso faz com que deixe de existir a proteção que evitaria o assoreamento e o carreamento de substâncias químicas. Como conseqüência, podem ocorrer impactos significativos, como mortandade de peixes. Segundo dados da Secretaria do Meio Ambiente do Estado de São Paulo, na década de oitenta, a bacia do rio Piracicaba apresentou a maior mortandade de peixes resultado de ações antrópicas dentre todas as bacias do estado. Outro indicador da degradação existente é o fato de o rio Piracicaba apresentar níveis de Demanda Bioquímica de Oxigênio (DBO) e Oxigênio Dissolvido (OD) que o enquadrariam nas classes 3 e 4 em boa parte de sua extensão, apesar de ser classificado como classe $2^{*}$.

A mesma Secretaria do Meio Ambiente (SMA, 1994), analisando indicadores ambientais da bacia do Atibaia, faz as seguintes considerações:

- A qualidade da água dos rios que cortam as cidades constituintes da bacia é baixa;

- Alguns trechos do rio Atibaia não apresentam qualidade compatível com sua classe;

- Existe risco à saúde pública em função da degradação ambiental;

- Para adequar a qualidade do rio Atibaia aos usos desejados, é necessário tratamento avançado das águas.

Outra desconformidade na bacia apontada em SMA (1994) é o fato de o rio Atibaia, em um trecho a jusante do ribeirão Anhumas até Itatiba, apresentar qualidade compatível com classe 4, condição bastante inferior à classe na qual está legalmente enquadrado. O mesmo estudo aponta que 58\% dos mananciais da bacia apresentam alto e altíssimo potencial de impacto. No local da captação da cidade de Sumaré, por exemplo, observam-se indicadores químicos e físicos com valores fora dos padrões estabelecidos pela legislação, com destaque às concentrações dos metais zinco, chumbo, cádmio e manganês.

\footnotetext{
* classes dadas pela resolução CONAMA 20 / 86.
} 


\subsection{Resultados Obtidos e Discussão}

Mencionado anteriormente, a simulação de cobrança aqui apresentada está baseada em trabalhos existentes, tal como o relatório da Secretaria do Meio Ambiente do Estado de São Paulo (SMA, 1994) que, visando ao reenquadramento dos corpos d'água da bacia do rio Piracicaba, apresenta estudos de metas ambientais para os quais foram geradas previsões de demandas de água e cargas poluidoras de DBO para o ano de 2010. Assim como este, outros trabalhos já analisados no quarto capítulo são utilizados na simulação e, por isso, são novamente apresentados.

Utilizando-se do relatório da SMA, Righetto (2001) avaliou a capacidade de pagamento de indústrias e de irrigantes da bacia do rio Atibaia no contexto da cobrança pelo uso e degradação dos recursos hídricos. Para a irrigação, o autor analisou a capacidade de pagamento anual de produtores de cana, milho, feijão e frutas, chegando a valores especificados em dólar por hectare (US\$/ha). Em relação ao setor industrial, foram analisadas algumas das principais empresas usuárias de água, representativas de diversos setores, para as quais chegou-se a montantes indicativos da capacidade de pagamento em algumas delas. Além disso, mediante a análise financeira executada, quando necessário, pode ser estimado um valor inicial para a capacidade de pagamento igual a $1 \%$ do faturamento bruto ou $5 \%$ do faturamento líqüido, divididos pela quantidade de água necessária à produção percentagens sugeridas pela Secretaria dos Recursos Hídricos do Estado do Ceará visando à implementação da cobrança pelo uso da água, conforme item (4.2.2).

Também com base no mesmo relatório da SMA, Azambuja (2000) realizou simulações da disponibilidade hídrica da bacia do rio Piracicaba, nas quais foram consideradas as demandas para abastecimento urbano, indústrias e irrigação, correspondentes a cada um dos compartimentos ambientais apresentados na figura (4.5). Para as simulações, utilizaram-se séries de vazões histórica e sintética como dados de entrada de um modelo de rede de fluxo denominado MODSIM*, cujo esquema relativo à porção da bacia do rio Atibaia é mostrado na figura (6.3).

\footnotetext{
* Modelo de simulação também utilizado pela companhia de saneamento básico de São Paulo (Sabesp), cujos "nós" da rede representam represas, demandas e reversões e são interligados por "links" representando rios e canais.
} 


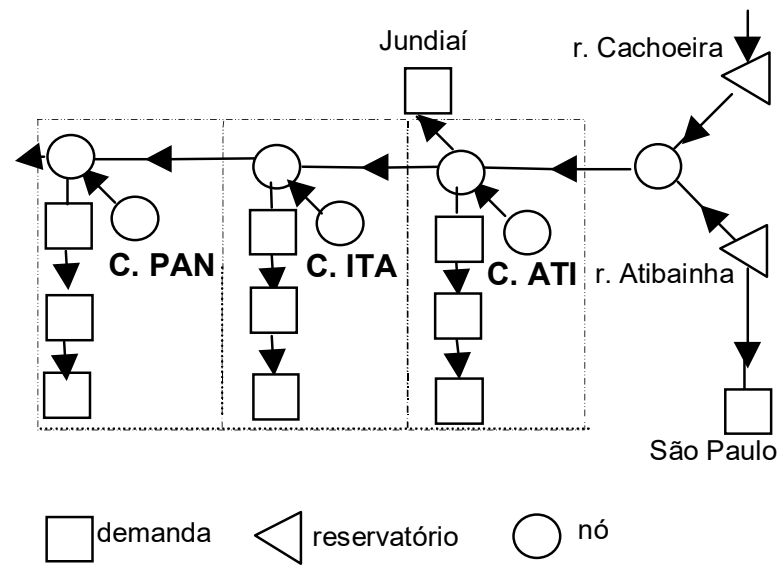

Figura 6.3 - Esquema da rede de fluxo relativo à porção da bacia do Atibaia

Assim, baseado em SMA (1994), Azambuja (2000) e Righetto (2001), pôde-se compilar os dados necessários para a aplicação das equações (5.1) a (5.10) do modelo de cobrança e, simulando-se cenários em diferentes trechos dos corpos d'água (representados pelos compartimentos ambientais), determinar o preço da água para alguns usuários da bacia do rio Atibaia. Em todos os cenários simulados, a vazão de referência mensal $\left(\mathrm{Q}_{\mathrm{r}}\right)$ adotada é calculada pelo modelo de simulação para uma ocorrência de 90\% do tempo, conforme curva de permanência da figura (6.4).

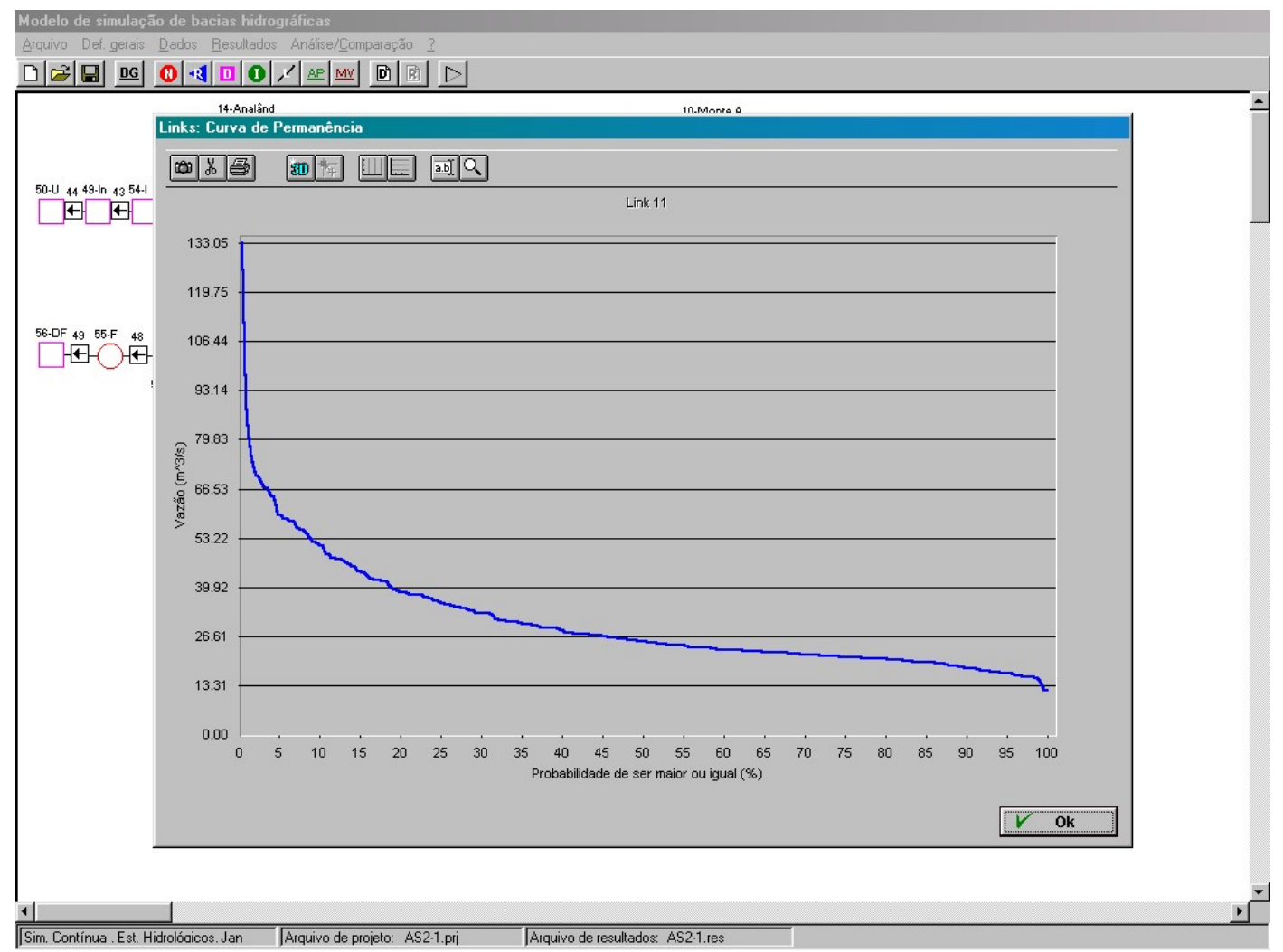

Figura 6.4 - Curva de permanência de trecho da bacia dada pelo MODSIM 
As cargas poluidoras e as demandas de água foram projetadas para o ano de 2010, assim como as capacidades de pagamento foram imaginadas para esse mesmo ano, apesar de originalmente calculadas com base em dados financeiros de anos anteriores. Essa extrapolação da capacidade de pagamento é possível já que, além dos valores serem em dólar, sua possível variação ao longo do tempo apenas sugere que os preços cobrados devem ser revistos periodicamente - o que ocorre em função dos Planos de Recursos Hídricos das bacias.

\subsubsection{Primeiro cenário: captação de água com pouca escassez}

A primeira simulação é feita para a captação relativa à irrigação de milho no compartimento C.ATI. O cenário escolhido representa um trecho com pequena escassez relativa de água, o que possibilitará observar o comportamento do modelo em situações sem problemas de quantidade de água e sem poluição pois, a fim de explorar as possibilidades de utilização do modelo, adota-se não existirem lançamentos anteriores e o valor a ser cobrado será definido com o uso das expressões (5.8), (5.9) e (5.10). Os valores necessários para a simulação, apresentados na tabela (6.1), têm como fonte as três referências já citadas e são explicados conforme o desenvolvimento das expressões do modelo.

Tabela 6.1 - Dados com base em SMA (1994); Azambuja (2000); Righetto (2001)

\begin{tabular}{c|c}
\hline vazão de referência & $Q_{r}=18,04 \mathrm{~m}^{3} / \mathrm{s}$ \\
\hline vazão “ambiental" & $Q_{7,10}=6,55 \mathrm{~m}^{3} / \mathrm{s}$ \\
\hline vazão captada & $Q_{\text {con }}=0,10 \mathrm{~m}^{3} / \mathrm{s}$ \\
\hline vazões a montante & $\sum Q_{\text {con }}=0,61 \mathrm{~m}^{3} / \mathrm{s}$ \\
\hline $\begin{array}{c}\text { capacidade de } \\
\text { pagamento }\end{array}$ & $\mathrm{CAP}=2,45$ \\
\hline
\end{tabular}

A obtenção do valor da tarifa se inicia com os cálculos das vazões disponível e de saturação, conforme expressões (5.8) e (5.9):

$$
\begin{gathered}
Q_{s}=18,04-6,55=11,49 \mathrm{~m}^{3} / \mathrm{s} \\
Q=11,49-0,10=11,39 \mathrm{~m}^{3} / \mathrm{s} \\
\text { sendo: } 18,04 \mathrm{~m}^{3} / \mathrm{s} \text { a vazão } Q_{r} \\
6,55 \mathrm{~m}^{3} / \mathrm{s} \text { a vazão } Q_{7,10} \\
0,10 \mathrm{~m}^{3} / \mathrm{s} \text { a vazão } Q_{c o n} .
\end{gathered}
$$


Neste cenário está sendo assumido o período anual, então, foi obtido apenas um valor para " $\mathrm{Q}_{\mathrm{r}}$ " (se o período considerado fosse mensal, caso dos próximos cenários, a análise resultaria em doze vazões de referência). A vazão obtida corresponde ao valor noventa da curva de permanência $\left(\mathrm{Q}_{90}\right)$ do trecho de captação da rede de fluxo do modelo de simulação matemática. Para o mesmo período, no cálculo da vazão disponível - expressão (5.9) - o valor de "Qcon" foi obtido analisando-se os consumos de água referentes a cada tipo de cultura irrigada na bacia do rio Atibaia e suas respectivas percentagens aplicadas à vazão de captação do setor no compartimento ambiental C.ATI.

A fim de ilustrar a situação mais crítica, foi suposto que a captação para irrigação de milho situa-se a jusante das outras captações com uso consuntivo de água. Portanto, o total consumido a montante da captação analisada é igual ao total no compartimento ambiental (aproximadamente $0,71 \mathrm{~m}^{3} / \mathrm{s}$ ) menos a vazão consumida $\prod \sum \mathrm{Q}_{\text {con }}=0,71 \mathrm{~m}^{3} / \mathrm{s}-0,10 \mathrm{~m}^{3} / \mathrm{s}$. Substituindo-se os valores até aqui apresentados na expressão (5.10), pode-se executar o cálculo do índice de qualidade:

$$
\begin{aligned}
& I=\frac{11,39-0,61}{11,49}=0,94 \\
& \text { sendo: } 11,39 \mathrm{~m}^{3} / \mathrm{s} \text { a vazão } Q_{;} \\
& 11,49 \mathrm{~m}^{3} / \mathrm{s} \text { a vazão } Q_{s} ; \\
& 0,61 \mathrm{~m}^{3} / \mathrm{s} \text { o somatório } \sum Q_{\text {con. }} .
\end{aligned}
$$

A capacidade de pagamento do setor avaliada para um período anual é $2,45 \mathrm{US} \$ 1000 \mathrm{~m}^{3}$, capacidade assumida considerando a situação de renda líquida mais crítica do trabalho de Righetto (2001) e já ajustada à unidade requerida para o modelo de cobrança. Conforme tabela (4.3), na definição desse valor, considerou-se o consumo anual de água para a produção de milho igual a $6.000 \mathrm{~m}^{3} / \mathrm{ha}$ e a capacidade de pagamento do produtor de 14,69 US\$/ha, avaliada para $90 \%$ de comprometimento de sua renda anual com a subsistência da família. Sobre o valor da capacidade de pagamento, mesmo que possa ser inexato, pode-se garantir coerência quanto à ordem de grandeza, fato suficiente ao objetivo das simulações de observar a aplicabilidade do modelo proposto. 
Para a definição do valor da água referente à escassez desse recurso e à disponibilidade a pagar do usuário, basta substituir os valores de "I" e "CAP" na expressão (5.7).

$K=2,45 \times(1-0,94)^{2.65}$
$K=0,0014$ US $\$ / 1000 m^{3}$

sendo: $2,45 \mathrm{US} \$ / 1000 \mathrm{~m}^{3}$ a capacidade de pagamento CAP;

0,94 o índice I.

O valor pago pela irrigação de milho anualmente (T) é conseguido utilizando-se a expressão (5.1), na qual o volume consumido anualmente é igual a

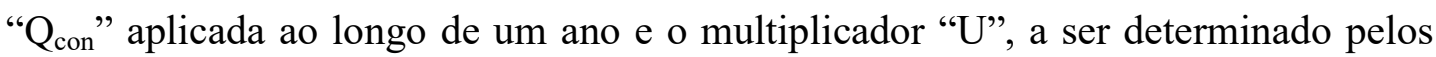
comitês de bacia, pode ser assumido igual à unidade sem prejuízo à analise do resultado:

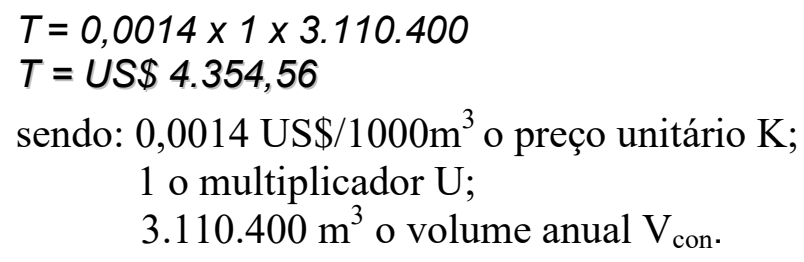

Comparando o valor do preço unitário à "CAP", observa-se que esse preço por volume de água é pequeno em relação à capacidade de pagamento do usuário, ou seja, “ 0,0014 US\$ $/ 1000 \mathrm{~m}^{3}<<<2,45$ US $\$ 1000 \mathrm{~m}^{3}$ ”. O resultado já era esperado neste primeiro cenário e reafirma o princípio do modelo, visto que há pouca escassez de recursos hídricos expressa pelo índice de qualidade muito próximo ao valor "um" (para $I=1$ não haveria cobrança).

\subsubsection{Cenário em ambiente MODSIM}

Para este item, a primeira simulação é reproduzida criando-se um algoritmo no modelo descrito no item (4.3.1), o que possibilita observar a versatilidade de aplicação da cobrança proposta quando integrada ao modelo de simulação de bacia hidrográfica. Fundamentalmente, podem ser obtidas mais facilmente as vazões de referência, as quais variam espacialmente e são diretamente retiradas da rede de fluxo calculando-se as vazões nos links de montante das demandas analisadas (conforme ilustrado na figura 6.4). As vazões consumidas - captadas ou utilizadas para diluição - podem estar em bancos de dados associados aos links ou aos compartimentos ambientais em questão. 
A figura (6.5) apresenta a tela do Modelo de Simulação com destaque para a planilha de cobrança, que serve como interface para calcular a tarifa cobrada de determinado usuário de água - especificando o uso com captação, com lançamento de poluente ou com ambas destinações.

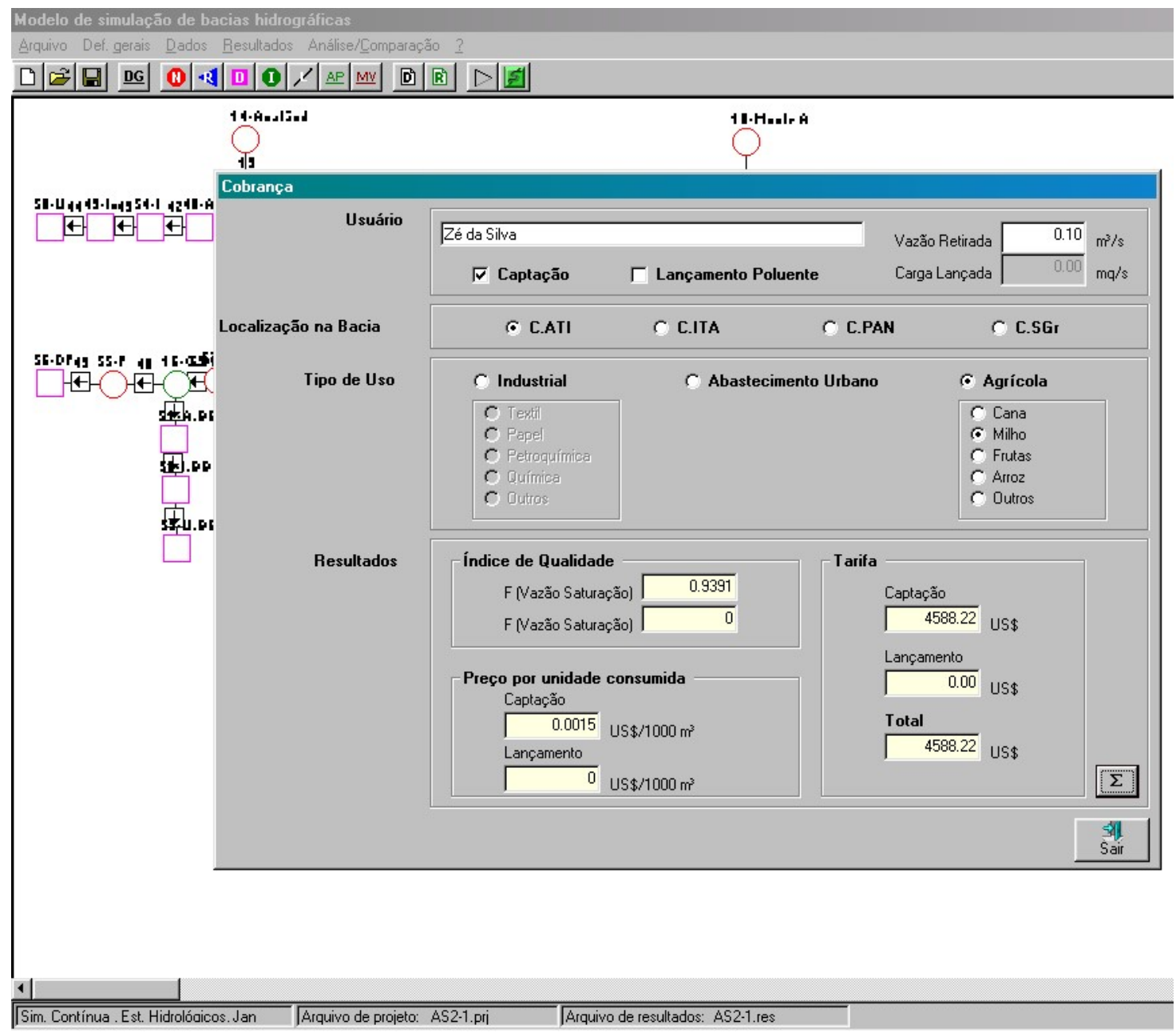

Figura 6.5 - Tela do MODSIM com destaque para a planilha de cobrança

Observando-se esta tela, pode-se notar que o último ícone na barra de ferramentas é um cifrão estilizado que quando acionado carrega a planilha "Cobrança". Na planilha, marcada a opção "Captação", ativa-se o campo correspondente à vazão retirada e, informando-se o compartimento ambiental e o tipo de uso, ativam-se os usuários para as diferentes possibilidades de capacidade de pagamento. No exemplo, entre as culturas existentes para o uso agrícola, tem-se a marcação para o milho. A partir desse instante, o programa já possui todas as informações necessárias para buscar o valor da vazão de referência na curva de 
permanência e os demais valores no banco de dados criado para a localização na bacia correspondente ao compartimento "C.ATI".

Assim, temos o índice de qualidade para a captação igual a "0,9391” e igual a zero para a poluição, já que não existe lançamento de poluentes, e o preço por unidade de água igual a " $0,0015 \mathrm{US} \$ / 1000 \mathrm{~m}^{3}$ ”. Como houve uma pequena diferença no arredondamento do índice de qualidade, que no item (6.2.1) apresentou o valor “0,94”, o menor valor significou uma maior escassez e, como conseqüência, um maior preço unitário. Ao final, a tarifa anual cobrada pelo uso da água na irrigação da cultura de milho na bacia ficou em U\$ 4.588,22.

Ainda sobre a planilha de cobrança, na parte reservada ao tipo de uso industrial, abastecimento urbano e agrícola - adotaram-se grupos de usuários correspondentes aos usos industrial e agrícola de forma a associá-los em segmentos daquilo que poderia ser representativo das diferentes capacidades de pagamento de suas categorias (visto em destaque na figura 6.6). Entretanto, a lista de usuários deve obedecer à lógica própria dos Comitês de Bacias e, a partir dos estudos de capacidade de pagamento efetuados, pode até ocorrer o extremo de conter grupo de um usuário, se a capacidade de pagamento deste assim exigir. Afinal, para o bom funcionamento do sistema, o usuário não pode ser cobrado muito abaixo de sua capacidade, o que deixaria de incentivar o uso racional da água, nem muito acima do quanto ele pode pagar quando o comitê entender que o usuário necessita, por exemplo, de subsídio para continuar sua atividade ou de prazo para adequar-se à escassez de água da bacia.

Além de ser apresentada uma planilha de cobrança inserida num modelo de simulação de bacias hidrográficas, juntamente com um banco de dados, como potencial auxílio aos gestores e usuários das águas, também se vislumbra a utilidade em se desenvolver um sistema de suporte à decisão. Associar um modelo de simulação de balanço hídrico, um banco de dados, um software de SIG, como interface mais apta à representação da bacia e à localização de seus usuários, e um modelo de cobrança cuja entrada possa ser alimentada pelo modelo de simulação pode constituir-se num sistema que, segundo Braga et al (1998), apresenta as 
técnicas mais recentes, adequadas e "amigáveis" aos tomadores de decisão na gestão integrada de recursos hídricos.

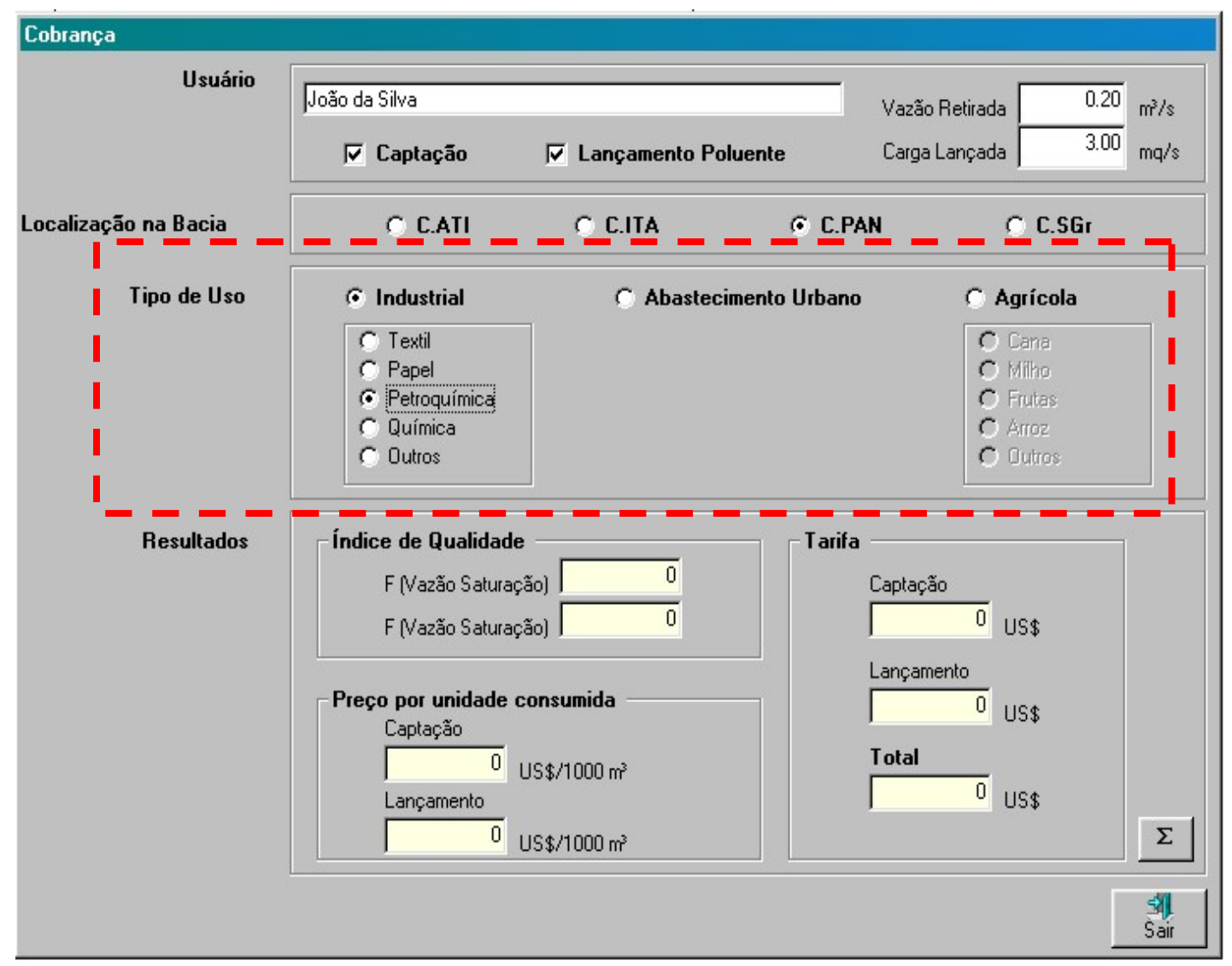

Figura 6.6 - Detalhe exemplificando planilha de cobrança no MODSIM

\subsubsection{Segundo cenário: captação de água e lançamento de efluente}

Ainda tendo como fonte de dados as três referências já citadas, para a segunda simulação são utilizados dados de uma indústria têxtil que retira água e lança efluente com carga de DBO no compartimento C.ITA e, pelo motivo exposto no primeiro cenário de explorar as possibilidades de aplicação do modelo, deve situar-se a jusante das outras atividades do compartimento que captam água e numa posição intermediária entre aquelas que poluem. Assim, como existem lançamentos a montante, faz-se necessária a análise sobre qual fator leva ao quadro de escassez mais crítico quando retirada água do corpo d'água: se a diminuição da vazão medida pela expressão (5.10) - ou se o aumento da carga poluidora - medida pela expressão (5.6). 
Iniciando esta análise, definiu-se que a montante da indústria simulada são lançados $30 \%$ da carga poluidora total do compartimento ambiental que, segundo SMA (1994), no ano de 2010 será de “88.657,41 mg DBO / s". É importante lembrar que as cargas de poluentes consideradas para o cálculo devem ser as cargas remanescentes após o tratamento e a depuração no corpo d'água. Em específico, é utilizada a carga poluidora residual apresentada em SMA (1994) como tendo essas características. O próprio trabalho citado aponta para a necessidade dessas considerações quando analisados poluentes não conservativos, utilizando um modelo baseado na fórmula de Streeter-Phelps em seus estudos para reenquadramento dos corpos d'água.

A análise comparativa para os índices de qualidade é feita tendo valores mensais como referência, com destaque à vazão " $\mathrm{Q}_{90}$ ", e está apresentada na tabela (6.2).

Tabela 6.2 - Análise comparativa do índice "I" para captação de água no C.ITA

\begin{tabular}{|c|c|c|c|c|c|c|c|}
\hline & $Q_{r}\left(m^{3} / s\right)$ & $Q_{s}\left(m^{3} / s\right)^{1}$ & $Q\left(\mathrm{~m}^{3} / \mathrm{s}\right)^{2}$ & I exp. $5.10^{3}$ & $\mathrm{C}_{\mathbf{s}}(\mathbf{m g} / \mathbf{s})^{4}$ & $\mathrm{C}(\mathrm{mg} / \mathrm{s})^{5}$ & I exp. $5.6^{6}$ \\
\hline jan & 30,12 & 21,73 & 21,72 & 0,90 & $150.600,00$ & $150.550,00$ & 0,82 \\
\hline fev & 37,41 & 29,02 & $29, .01$ & 0,92 & $187.050,00$ & $187.000,00$ & 0, 80 \\
\hline mar & 40,66 & 32,27 & 32,26 & 0,93 & $203.300,00$ & $203.250,00$ & $0,8 \pi$ \\
\hline$a b r$ & 29,07 & 20,68 & 20,67 & 0,89 & $145.350,00$ & $145.300,00$ & (0), 82 \\
\hline mai & 13,47 & 5,08 & 5,07 & 0,57 & $67.350,00$ & $67.300,00$ & 0,60 \\
\hline jun & 17,25 & 8,86 & 8,85 & 0,75 & $86.250,00$ & $86.200,00$ & (0), (29) \\
\hline jul & 14,21 & 5,82 & 5,81 & 0, 62 & $71.050,00$ & $71.000,00$ & 0, 62 \\
\hline ago & 13,08 & 4,69 & 4,68 & 0,53 & $65.400,00$ & $65.350,00$ & 0,59 \\
\hline set & 12,78 & 4,39 & 4,38 & 0,50 & $63.900,00$ & $63.850,00$ & 0,58 \\
\hline out & 12,64 & 4,25 & 4,24 & (0),48 & $63.200,00$ & $63.150,00$ & 0,58 \\
\hline nov & 15,93 & 7,54 & 7,53 & 0,71 & $79.650,00$ & $79.600,00$ & $0,0,7$ \\
\hline dez & 18,78 & 10,39 & 10,38 & 0,79 & $93.900,00$ & $93.850,00$ & $0, \pi 2$ \\
\hline $\begin{array}{l}\text { exp } \\
\text { exp } \\
\sum Q_{c}\end{array}$ & são (5.9) & $0^{x, 10}=0$ & $\begin{array}{l}n^{3} / s \\
n^{3} / s\end{array}$ & \multicolumn{4}{|c|}{$\begin{array}{l}{ }^{4} \text { exp. }(5.4): c_{p q}=5,00 \mathrm{mg} / \mathrm{l}\left(\mathrm{DBO}_{\text {máx }}\right) \\
{ }_{5} \text { expressão }(5.5)\end{array}$} \\
\hline
\end{tabular}

De acordo com a análise realizada, nos primeiros e nos últimos meses do ano quando as vazões são maiores, a escassez do recurso hídrico se mostra mais crítica em função da falta de água para a diluição de poluentes, o que implica na utilização 
da expressão (5.6) para o cálculo do preço da água captada de maneira consuntiva. Especificamente, em junho apresenta-se a mesma condição de boa vazão. Nos outros meses, exceção feita ao mês de julho, a escassez do recurso hídrico se mostra mais crítica em relação à vazão disponível do corpo d'água, o que implica na utilização da expressão (5.10). Curiosamente, no mês de julho, a qualidade da água se mostra comprometida na mesma medida, seja pela pouca quantidade de água ou pelo excesso de poluição.

Para o cálculo do valor a ser cobrado quando do lançamento de poluentes, basta aplicar as expressões (5.4), (5.5) e (5.6) utilizando uma vazão consumida equivalente segundo a expressão (5.3). Visto que é dado do problema a carga lançada $-\mathrm{C}_{\mathrm{e}}=2002 \mathrm{mg} \mathrm{DBO} / \mathrm{s}$ - e não a vazão e a concentração do efluente, não é necessário o uso da expressão (5.2). Sendo assim, tem-se:

$$
Q_{\text {con }}=2002 /\left(5,00 \times 10^{3}\right)=0,40 \mathrm{~m}^{3} / \mathrm{s}
$$

sendo: $2002 \mathrm{mg} \mathrm{DBO} / \mathrm{s}$ a carga $\mathrm{C}_{\mathrm{e}}$;

$5,00 \mathrm{mg} / \mathrm{l}$ o padrão $\mathrm{c}_{\mathrm{pq}}$.

A seguir, a tabela (6.3) apresenta os valores cobrados para a captação consuntiva e para os lançamentos relativos ao cenário simulado, já com os valores do índice de qualidade calculados para a vazão utilizada na diluição de DBO $\left(Q_{\text {con }}=0,40 \mathrm{~m}^{3} / \mathrm{s}\right)$. Na mesma tabela, o total a ser pago pelo usuário industrial é igual à soma da tarifa relativa à captação de água mais àquela relativa ao lançamento de poluente. Esclarecendo os cálculos das tarifas mensais, o valor da capacidade de pagamento mensal foi obtido dividindo-se o valor da capacidade anual (igual ao patrimônio líqüido da empresa de 4.274,61 mil US\$ ${ }^{*}$ ) por doze e pelo volume mensal de água necessário à atividade. O volume para o cálculo de CAP é a soma dos volumes consumidos para os dois usos, os quais foram obtidos referentes às duas vazões $\left(0,01 \mathrm{~m}^{3} / \mathrm{s}\right.$ de vazão de captação e $0,40 \mathrm{~m}^{3} / \mathrm{s}$ de vazão equivalente para o lançamento de efluentes) e para o tempo de um mês dado em segundos.

Concordando com Araújo (1998), para a obtenção da capacidade de pagamento deve ser utilizada a vazão necessária à produção e não a consumida, porque usuários ineficientes em termos tecnológicos seriam beneficiados com uma

\footnotetext{
${ }^{*}$ Valor adotado considerando Righeto (2001).
} 
redução relativa do preço da água. Assim sendo, a carga residual adotada foi aquela correspondente a uma eficiência de tratamento do efluente de $80 \%$, ou seja, no cálculo da capacidade de pagamento toma-se como base o poluente residual tratado com a mínima eficiência exigida por lei, que na prática corresponde à necessidade máxima de água para fim de diluição, transporte e assimilação de poluentes ${ }^{*}$. Nesta simulação, admitindo-se essa eficiência, a carga residual é de $173 \mathrm{~kg} \mathrm{DBO} /$ dia no efluente industrial ou, convertendo-se as unidades, $2002 \mathrm{mg} \mathrm{DBO} / \mathrm{s}$ (já utilizados no cálculo da vazão consumida conforme expressão 5.3).

Tabela 6.3 - Preço por unidade de água e total arrecadado do usuário no C.ITA

\begin{tabular}{|c|c|c|c|c|c|c|c|c|}
\hline & $\begin{array}{c}Q_{r} \\
\left(m^{3} / s\right)\end{array}$ & captação & $\underset{\left(U S \$ / 1000 m^{3}\right)}{K^{1}}$ & $\begin{array}{c}\mathrm{T}_{\text {captação }}{ }^{2} \\
\text { (US\$) }\end{array}$ & $\underset{\text { poluição }}{\text { I }}$ & $\begin{array}{r}K^{1} \\
\left(\mathrm{US} \$ / 1000 \mathrm{~m}^{3}\right)\end{array}$ & $\begin{array}{c}T_{\text {poluição }}{ }^{3} \\
\text { (US\$) }\end{array}$ & $\begin{array}{l}T_{\text {total }}{ }^{4} \\
\text { (US\$) }\end{array}$ \\
\hline jan & 30,12 & 0,82 & 3,56 & 92,38 & 0,81 & 4,11 & $4.261,25$ & $4.353,63$ \\
\hline fev & $37, .41$ & 0,86 & 1,83 & 47,49 & 0,85 & 2,19 & $2.270,59$ & $2.318,08$ \\
\hline mar & 40,66 & 0,87 & 1,50 & 38,93 & 0,86 & 1,83 & $1.897,34$ & $1.936,27$ \\
\hline$a b r$ & 29,07 & 0,82 & 3,56 & 92,38 & 0,80 & 4,71 & $4.883,33$ & $4.975,71$ \\
\hline mai & 13,47 & 0,57 & 35,81 & 929,27 & 0,58 & 33,64 & $34.877,95$ & $35.807,22$ \\
\hline jun & 17,25 & 0,69 & 15,04 & 390,29 & 0,67 & 17,76 & $18.413,57$ & $18.803,86$ \\
\hline jul & 14,21 & 0,62 & 25,81 & 669,77 & 0,60 & 29,56 & $30.647,81$ & $31.317,58$ \\
\hline ago & 13,08 & 0,53 & 45,32 & $1.176,05$ & 0,56 & 38,06 & $39.460,61$ & $40.636,66$ \\
\hline set & 12,78 & 0,50 & 53,40 & $1.385,73$ & 0,55 & 40,39 & $41.876,35$ & $43.262,08$ \\
\hline out & 12,64 & 0,48 & 59,25 & $1.537,54$ & 0,55 & 40,39 & $41.876,35$ & $43.413,89$ \\
\hline nov & 15,93 & 0,67 & 17,76 & 460,87 & 0,64 & 22,36 & $23.182,85$ & $23.643,72$ \\
\hline dez & 18,78 & 0,72 & 11,49 & 298,17 & 0,70 & 13,79 & $14.297,47$ & $14.595,64$ \\
\hline
\end{tabular}

Finalmente, somando os totais mensais da tabela, tem-se que o total anual pago pelo usuário é igual a US\$265.064,34, sendo a maior parte devida à vazão consumida para o lançamento de efluentes. Apesar de a escassez ser maior do que no primeiro cenário, ainda existe boa qualidade ambiental e o valor anual a ser pago pelo usuário é bastante inferior à sua capacidade de pagamento (US\$265.064,34<<US\$ 4.274.610,00).

\footnotetext{
* Na prática, o usuário que utilizar a tecnologia mais eficiente disponível no mercado é beneficiado.
} 


\subsubsection{Terceiro cenário: captação e poluição com escassez de água}

A terceira simulação é feita imaginando-se a mesma indústria do segundo cenário localizada no compartimento C.PAN. O objetivo é mostrar o aumento do valor pago pelo mesmo usuário do cenário anterior quando este se instala num trecho de corpo d'água saturado que, segundo SMA (1994), é a realidade apresentada pelo Compartimento Ambiental Pinheiros/Anhumas. Logo, procurando manter um paralelo entre o segundo e o terceiro cenários, valem todas as observações da simulação anterior e a análise comparativa para os índices de qualidade já está apresentada na tabela (6.4).

Tabela 6.4 - Análise comparativa do índice "I" para captação de água no C.PAN

\begin{tabular}{|c|c|c|c|c|c|c|c|}
\hline & $Q_{r}\left(m^{3} / s\right)$ & $Q_{s}\left(m^{3} / s\right)^{1}$ & $Q\left(\mathrm{~m}^{3} / \mathrm{s}\right)^{2}$ & $\mathbf{I} \exp .5 .10^{3}$ & $\mathrm{C}_{\mathbf{s}}(\mathrm{mg} / \mathrm{s})^{4}$ & $\mathrm{C}(\mathrm{mg} / \mathrm{s})^{5}$ & I exp. $5.6^{6}$ \\
\hline jan & 37,60 & 27,44 & 27,43 & 0,86 & $188.000,00$ & $187.950,00$ & $=0,01$ \\
\hline fev & 43,95 & 33,79 & 33,78 & 0,89 & $219.750,00$ & $219.700,00$ & 0,113 \\
\hline mar & 45,32 & 35,16 & 35,15 & 0,89 & $226.600,00$ & $226.550,00$ & (0, 1 16 \\
\hline$a b r$ & 33,32 & 23,16 & 23,15 & 0,84 & $166.600,00$ & $166.550,00$ & $=0,14$ \\
\hline mai & 16,80 & 6,64 & 6,63 & 0,44 & $84.000,00$ & $83.950,00$ & $=\pi, 2 \pi$ \\
\hline jun & 18,76 & 8,60 & 8,59 & 0,57 & $93.800,00$ & $93.750,00$ & $=\pi, 02$ \\
\hline jul & 13,84 & 3,68 & 3,67 & $-0,02$ & $69.200,00$ & $69.150,00$ & $=\pi, \pi, 75$ \\
\hline ago & 14,63 & 4,47 & 4,46 & 0,16 & $73.150,00$ & $73.100,00$ & $=\pi, 60$ \\
\hline set & 12,75 & 2,59 & 2,58 & $-0,44$ & $63.750,00$ & $63.700,00$ & $=\pi, 90$ \\
\hline out & 14,04 & 3,88 & 3,87 & 0,04 & $70.200,00$ & $70.150,00$ & $=\pi, \pi \pi$ \\
\hline nov & 19,18 & 9,02 & 8,01 & 0,59 & $95.900,00$ & $95.850,00$ & $=0,98$ \\
\hline dez & 25,61 & 15,45 & 15,44 & 0,76 & $128.050,00$ & $128.000,00$ & $=0,49$ \\
\hline & $\begin{array}{l}\text { pressão } \\
2_{\text {con }}=3,73\end{array}$ & 9): $Q_{\text {con }}=0$ & $\begin{array}{l}16 \mathrm{~m}^{3} / \mathrm{s} \\
1 \mathrm{~m}^{3} / \mathrm{s}\end{array}$ & \multicolumn{4}{|c|}{$\begin{array}{l}{ }^{4} \text { exp. }(5.4): c_{p q}=5,00 \mathrm{mg} \\
{ }^{5} \text { expressão }(5.5) \\
{ }^{6} \Sigma C_{e}=190.357,63 \mathrm{mg} / \mathrm{s}\end{array}$} \\
\hline
\end{tabular}

Diferentemente da comparação entre os índices de qualidade para o segundo cenário, para este compartimento não existe alternância dos valores críticos entre meses com maiores vazões e aqueles mais secos. Mesmo nos meses de julho e 
setembro, quando a vazão está abaixo do limite estabelecido como parâmetro ambiental, o estado de escassez da água é dado pela carga de poluição.

Outra diferença marcante entre este cenário e os anteriores é o fato de o trecho simulado (C.PAN) possuir uma qualidade ambiental tão inferior aos trechos dos outros compartimentos ambientais que, com exceção dos meses de fevereiro e março nos quais acontecem as maiores vazões, o comprometimento dos recursos hídricos sempre ultrapassa os indicadores de saturação dados pelo modelo. No mês mais seco, setembro, a poluição leva o corpo d'água a apresentar uma qualidade quase duas vezes pior do que o padrão. As conseqüências dessa saturação ambiental serão refletidas nos preços unitários da água, conforme mostrado na tabela (6.5).

Tabela 6.5 - Preço por unidade de água e total arrecadado do usuário no C.PAN

\begin{tabular}{|c|c|c|c|c|c|c|c|c|}
\hline & $\begin{array}{c}Q_{r} \\
\left(m^{3} / s\right)\end{array}$ & $\begin{array}{r}\boldsymbol{I} \\
\text { captação }\end{array}$ & $\begin{array}{r}K^{1} \\
\left(\mathbf{U S} \$ / 1000 \mathrm{~m}^{3}\right)\end{array}$ & $\begin{array}{l}T_{\text {captação }}{ }^{2} \\
\text { (mil US\$) }\end{array}$ & $\begin{array}{c}\text { I } \\
\text { poluição }\end{array}$ & $\begin{array}{r}K^{1} \\
\left(\mathrm{US} \$ 11000 \mathrm{~m}^{3}\right)\end{array}$ & $\begin{array}{l}T_{\text {poluição }}{ }^{3} \\
\text { (mil US\$) }\end{array}$ & $\begin{array}{c}T_{\text {total }}^{4} \\
\text { (mil US\$) }\end{array}$ \\
\hline jan & 37,60 & $-0,01$ & 344,14 & 8,93 & $-0,02$ & 353,24 & 366,24 & 375,17 \\
\hline fev & 43,95 & 0,13 & 231,74 & 6,01 & 0,12 & 238,87 & 247,66 & 253,67 \\
\hline mar & 45,32 & 0,16 & 211,16 & 5,48 & 0,15 & 217,89 & 225,91 & 231,39 \\
\hline$a b r$ & 33,32 & $-0,14$ & 474,32 & 12,31 & $-0,15$ & 485,43 & 503,29 & 515,60 \\
\hline mai & 16,80 & $-1,27$ & $2.942,70$ & 76,36 & $-1,29$ & $3.011,91$ & $3.122,74$ & $3.199,10$ \\
\hline jun & 18,76 & $-1,02$ & $2.160,03$ & 56,05 & $-1,05$ & $2.246,08$ & $2.328,74$ & $2.384,79$ \\
\hline jul & 13,84 & $-1,75$ & $4.892,26$ & 126,95 & $-1,78$ & $5.034,97$ & $5.220,26$ & $5.347,21$ \\
\hline ago & 14,63 & $-1,60$ & $4.216,55$ & 109,42 & $-1,63$ & $4.346,71$ & $4.506,66$ & $4.616,08$ \\
\hline set & 12,75 & $-1,99$ & $6.106,70$ & 158,47 & $-2,02$ & $6.270,42$ & $6.501,17$ & $6.659,64$ \\
\hline out & 14,04 & $-1,71$ & $4.705,94$ & 122,12 & $-1,74$ & $4.845,26$ & $5.023,57$ & $5.145,69$ \\
\hline nov & 19,18 & $-0,98$ & $2.048,52$ & 53,16 & $-1,00$ & $2.103,82$ & $2.181,24$ & $2.234,40$ \\
\hline dez & 25,61 & $-0,49$ & 964,32 & 25,02 & $-0,50$ & 981,57 & $1.017,69$ & $1.042,71$ \\
\hline
\end{tabular}

Já indicado pelos baixos valores dos índices de qualidade calculados na tabela (6.4), o preço unitário da água e o total pago pela indústria são bem maiores para o usuário localizado neste trecho da bacia hidrográfica. No mês de setembro, cuja vazão de referência apresenta o menor valor, o preço da água chega a ser dezoito vezes maior do que a capacidade de pagamento. Quanto ao total anual pago pelo usuário de US\$ 32.005.450,00, ele é sete vezes e meio superior à capacidade de 
pagamento de US\$4.274.610,00 e, mais do que ser considerado “indutor" de um comportamento ambiental desejado, deve forçar mudanças profundas no cenário apresentado.

Obviamente, se a cobrança estivesse implantada na bacia anteriormente ao quadro de saturação aguda, esse cenário de escassez não chegaria a cabo, pois os valores cobrados acima da capacidade de pagamento sugeririam uma mudança de localização na bacia (ou de bacia) ou fariam com que o usuário procurasse estruturar suas atividades, a fim de consumir menos água racionalizando o uso ou racionando a produção. Além disso, estando o sistema de cobrança definido em função de vazões consumidas mensais, pode-se imaginar um cenário com menor escassez no qual o usuário procuraria estruturar suas atividades para que o fluxo de produção considerasse os meses com maior ou menor disponibilidade de água.

\subsubsection{Quarto cenário: transposição de bacias}

A quarta simulação é feita imaginando-se a mesma condição explorada por Souza (1995) ao analisar a captação de água para a Região Metropolitana de São Paulo (RMSP) através da transposição de bacia pelo Sistema Cantareira, já representada nas figuras (6.2) e (6.3). O objetivo é simular a cobrança sobre essa modalidade de uso e analisar as diferenças entre as tarifas obtidas com o modelo de cobrança proposto e com o modelo cuja concepção da curva de cobrança serviu como base para este. Logo, procurando manter um paralelo entre os dois modelos, são utilizados os dados de entrada apresentados em Souza (1995), conforme tabela (6.6). A combinação dos dados representa nove diferentes cenários, nos quais variam as vazões de referência, as cargas poluidoras a montante da transposição e as vazões de transposição.

Em função de o modelo apresentado por Souza cobrar apenas considerando a escassez de água dada pela poluição, e sendo a análise comparativa, não será efetuado o cálculo do índice de qualidade em função da vazão mínima (equações 5.8 a 5.10). Para o cálculo do índice de qualidade função da poluição máxima, já dadas as cargas poluidoras $\left(\Sigma \mathrm{C}_{\mathrm{e}}\right)$, basta subtrair da vazão originalmente disponível para o recebimento dos poluentes - vazão de referência $\left(Q_{r}\right)$ - a vazão captada para a transposição $\left(Q_{c o n}\right)$. 
Tabela 6.6 - Cenários com dados de saturação do rio, vazão do rio e vazão captada da bacia do Piracicaba para a RMSP (Adaptado: Souza, 1995)

\begin{tabular}{c|c|c|c|c|c|c|c|c|c}
\hline Cenários & $\mathbf{1}$ & $\mathbf{2}$ & $\mathbf{3}$ & $\mathbf{4}$ & $\mathbf{5}$ & $\mathbf{6}$ & $\mathbf{7}$ & $\mathbf{8}$ & $\mathbf{9}$ \\
\hline $\mathbf{C}_{\mathrm{pq}}(\mathbf{m g} / \mathbf{l})$ & 5 & 5 & 5 & 5 & 5 & 5 & 5 & 5 & 5 \\
\hline $\mathbf{Q}_{\mathbf{r}}\left(\mathbf{m}^{\mathbf{3}} / \mathbf{s}\right)$ & 55 & 55 & 55 & 55 & 55 & 80 & 110 & 110 & 110 \\
\hline $\mathbf{Q}_{\mathrm{con}}\left(\mathbf{m}^{\mathbf{3}} / \mathbf{s}\right)$ & 30 & 30 & 29 & 15 & 15 & 30 & 30 & 30 & 30 \\
\hline$\Sigma \mathbf{C}_{\mathbf{e}}(\mathbf{m g} / \mathbf{s})$ & 125.000 & 122.500 & 125.000 & 125.000 & 122.500 & 122.500 & 122.500 & 100.000 & 50.000 \\
\hline
\end{tabular}

O valor da capacidade de pagamento adotado para a simulação será de 15 US\$ $/ 1000 \mathrm{~m}^{3}$, valor baseado em SRH (2001), a qual considerou-a variando entre 10 e $15 \mathrm{R} \$ / 1000 \mathrm{~m}^{3}$ tendo como base estudos que analisaram a capacidade de pagamento do setor de abastecimento humano no Ceará. A conversão do valor em moeda norte-americana baseou-se em seu valor médio frente ao real na época da publicação dos estudos - 1,19 R\$/US\$ - e admitindo-se que as capacidades de pagamento encontradas no Ceará não apresentam ordem de grandeza diferentes das encontradas na região metropolitana de São Paulo, sendo isto o necessário para o objetivo desta aplicação. Considerando esta situação e utilizando as equações (5.1) a (5.7), tem-se o cálculo das tarifas para os nove cenários da tabela (6.6). Esses valores estão apresentados na tabela (6.7), onde também se encontra a tarifa a ser paga por consumo, “T econ”, apresentada em Souza (1995) para esta aplicação.

Tabela 6.7 - Preços por unidade de água e totais arrecadados por ano do modelo proposto e respectivos totais do modelo base

\begin{tabular}{|c|c|c|c|c|c|}
\hline Cenários & $\operatorname{exp.} 5.6^{\boldsymbol{I}}$ & $\left(\mathrm{US} \$ / 1000 \mathrm{~m}^{3}\right)^{K^{1}}$ & $\left(1000 \mathrm{~m}^{3}\right)^{V_{c o n}}$ & $\begin{array}{c}\mathrm{T}_{\text {transposicão }}{ }^{2} \\
\text { (mil US\$/ano) }\end{array}$ & $\begin{array}{c}\mathrm{T}_{\text {econ }}{ }^{3} \\
\text { (mil US\$/ano) }\end{array}$ \\
\hline 1 & 0,00 & 15,00 & $9,33 \times 10^{5}$ & $13.995,00$ & $202.980,28$ \\
\hline 2 & 0,01 & 14,61 & $9,33 \times 10^{5}$ & $13.627,18$ & $15.573,88$ \\
\hline 3 & 0,02 & 14,22 & $9,02 \times 10^{5}$ & $12.826,44$ & $5.034,02$ \\
\hline 4 & 0,27 & 6,51 & $4,67 \times 10^{5}$ & $3.036,92$ & $1.827,45$ \\
\hline 5 & 0,28 & 6,28 & $4,67 \times 10^{5}$ & $2.929,62$ & $1.766,11$ \\
\hline 6 & 0,32 & 5,40 & $9,33 \times 10^{5}$ & $5.036,41$ & $2.125,82$ \\
\hline 7 & 0,51 & 2,27 & $9,33 \times 10^{5}$ & $2.113,45$ & $1.094,73$ \\
\hline 8 & 0,55 & 1,81 & $9,33 \times 10^{5}$ & $1.686,50$ & 776,89 \\
\hline 9 & 0,64 & 0,79 & $9,33 \times 10^{5}$ & 741,37 & 240,78 \\
\hline
\end{tabular}


Observando-se os valores do índice de qualidade e das tarifas para as duas propostas de cobrança, têm-se como cenários menos críticos aqueles cujas vazões de referências são maiores - cenários 6 a 9 - ou cujos volumes consumidos são bem menores - cenários 4 e 5 . Para todos estes casos, temos o valor da tarifa proposta

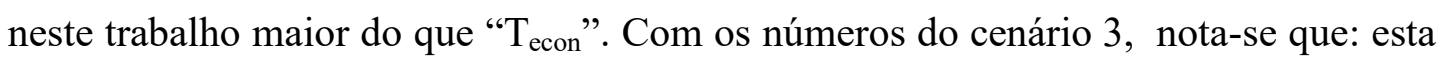
situação se mantém até ser atingido $98 \%$ da carga de saturação do meio $(I=0,02)$; a diferença entre os valores das tarifas varia pouco em relação ao total arrecadado; e, para uma mesma vazão de referência, esta diferença proporcional é um pouco menor quanto mais comprometido estiver o corpo d'água. Em função das equações para a curva de cobrança escolhidas por Souza, atingido o patamar representado pelo índice de qualidade igual a 0,02 , rapidamente " $\mathrm{T}_{\text {econ}}$ " supera monetariamente a tarifa

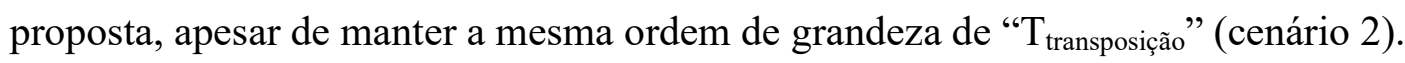

Entretanto, quando o cenário da transposição atinge o limite da saturação do meio, "T $\mathrm{T}_{\text {econ" }}$ extrapola em muito o valor da tarifa proposta (cenário 1). Passado este

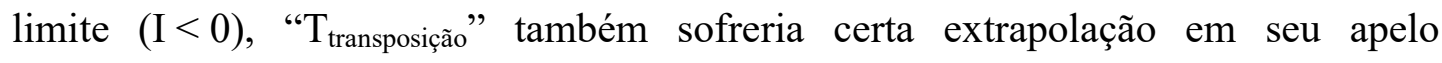
financeiro para a diminuição efetiva da poluição. Na formulação da equação (5.7), este apelo financeiro foi traduzido numericamente dobrando-se o valor cobrado correspondente à capacidade de pagamento do usuário quando superados aproximadamente $30 \%$ da saturação. Nesta aplicação, isto resultaria numa arrecadação de 27.990 mil US\$/ano e, mesmo assim, estar-se-ia na casa das dezenas de milhões de dólares, enquanto " $\mathrm{T}_{\text {econ" }}$ continuaria crescendo em centenas de milhões de dólares.

Essas convergências e diferenças entre os valores a serem cobrados segundo os dois modelos, representados por " $\mathrm{T}_{\text {transposição }} \mathrm{e}$ " $\mathrm{T}_{\text {econ" }}$ ", ocorrem devido ao fato de a proposta aqui apresentada ter mantido o conceito da curva de cobrança (dado pelo desenho exponencial), mas ter abandonado a valoração da água baseada em custo de tratamento de efluentes.

Além disso, esta aplicação também serve para apresentar duas vantagens da atual proposta. Já dito anteriormente, como o índice de qualidade para o cálculo de “ $\mathrm{T}_{\text {econ" }}$ só considera a saturação do meio mediante a poluição deste, não foi simulada a resposta do modelo para uma possível situação crítica em termos de vazão 
disponível. Porém, se for considerada a transposição como a primeira captação do trecho estudado $\left(\Sigma \mathrm{Q}_{\mathrm{con}}=0\right)$, adotada a vazão mínima apresentada por Souza $\left(\mathrm{Q}_{7,10}=25 \mathrm{~m}^{3} / \mathrm{s}\right)$ e tomado o cenário 1 , também se tem a saturação do meio $(\mathrm{I}=0$, equações 5.8 a 5.10) e o valor cobrado ao usuário é o mesmo dado em função da poluição $\left(\mathrm{K}=15 \mathrm{US} \$ / 1000 \mathrm{~m}^{3}\right)$. Na concepção da forma de cobrança aqui apresentada, seja devido à poluição seja devido à diminuição do volume, é dado à água o mesmo valor monetário quando atingido o mesmo grau de escassez.

Por fim, a partir dos cenários gerados neste capítulo, observam-se aspectos envolvendo a cobrança sobre o uso da água que exemplificam o quanto este instrumento oferece alternativas para o planejador ambiental traçar caminhos e eleger prioridades factíveis com a visão sistêmica do meio, própria do desenvolvimento ecologicamente equilibrado. Nesse sentido, as considerações feitas aqui procuram demonstrar as facilidades oferecidas pela simulação à operação das informações, já que a modelagem deve indicar o grau de incerteza, a divisibilidade e a interferência de determinado uso na disponibilidade da água. Finalmente, observada a validade do modelo proposto, poderão ser apresentados estes resultados como subsídio à efetiva implementação da cobrança pelo uso da água.

Como indicativo dessa aplicabilidade do modelo, ao serem analisados os números apresentados por Dinar e Subramanian (1997), também citados pela Secretaria dos Recursos Hídricos do Estado do Ceará, constata-se que os preços simulados - por unidade de volume - são compatíveis com os valores cobrados em vários países do mundo. Analisando-se os valores apresentados pelos autores, apenas o preço encontrado para a irrigação ficou abaixo do menor valor relativo ao uso agrícola de $0,10 \mathrm{US} \$ / 1000 \mathrm{~m}^{3}$ cobrado na Espanha. Entretanto, isso pode ser explicado porque o primeiro cenário simulado apresenta índice de qualidade muito próximo ao valor máximo e, se assim fosse, nem estaria configurada a escassez e a cobrança não existiria. Por outro lado, passando a existir um quadro de escassez de água pouco maior, o índice de qualidade indicaria um valor mais próximo da capacidade de pagamento de $2,45 \mathrm{US} \$ / 1000 \mathrm{~m}^{3}$ e o preço unitário da água poderia encontrar-se facilmente acima do limite inferior supracitado. 
Prova disto seria dada ao realizar-se a mesma simulação do primeiro cenário trocando-se a captação para irrigação de milho pela irrigação de frutas, cujo irrigante possuísse a capacidade de pagamento igual ao valor médio das hipóteses analisadas por Righetto (2001). Neste caso, o preço por unidade de água consumida seria de $0,07 \mathrm{US} \$ / 1000 \mathrm{~m}^{3}$, valor bem mais próximo do mínimo referido, mesmo frente à boa condição de qualidade da água existente no compartimento ambiental simulado.

Também mediante a análise dos números apresentados por Dinar e Subramanian (1997), nota-se grande diferença entre os limites inferior e superior dos valores de cobrança no mundo. Assim, afirma-se novamente a vantagem da utilização da capacidade de pagamento dos diferentes usuários na formação do preço da água, pois, dessa maneira, além de a cobrança contemplar o uso múltiplo de água, ela serve como balizamento aos valores cobrados a fim de que o agente econômico que está exaurindo o meio ambiente não possa ter capacidade de pagar pelos custos dessa degradação. 


\section{Conclusão}

Neste trabalho foi desenvolvido e aplicado um modelo de cobrança sobre o uso da água que considera como princípio base a sustentabilidade ambiental, medida pela adequada gestão da escassez de água. Essa condição necessária pode ser vista como o objetivo geral da forma de cobrança aqui proposta e, compondo a busca desse objetivo, a racionalização econômica e a viabilização financeira podem ser caracterizadas como constituintes do processo. Perseguido esse objetivo, o caráter de instrumento econômico - instrumento que visa a administrar a escassez de recursos está preservado pelo modelo.

Traduzindo a sustentabilidade ambiental em termos de instrumentos de gestão dos recursos naturais, só tem chance de êxito uma cobrança em cuja metodologia a capacidade de suporte for dada pelo meio e não pelo desenvolvimento tecnológico. Afinal, acreditar que mediante investimentos financeiros em infra-estrutura serão corrigidos indefinidamente os impactos advindos dos usos da água é supor erroneamente que o meio econômico é limitante do meio ambiente e não o contrário.

Diferente da maioria das propostas de cobrança, que valoram a água baseadas em custos de tratamento de resíduos e de obras hidráulicas, a curva para cobrança representada pela figura (5.1) foi construída fundamentada na sustentabilidade do meio independentemente destas intervenções, residindo nesse fato a vantagem do modelo agora proposto. Mesmo que a cobrança seja baseada em um padrão ambiental corretamente definido, a partir do qual se torna mais caro captar água ou lançar poluentes do que racionalizar usos, o parâmetro para ser apresentado o veredicto "mais caro" não pode ser limitado pelo custo de obras e tecnologias, cuja "sustentabilidade" pode acabar no curto prazo se houver um crescimento econômico acelerado. 
Também vai ao encontro de uma sustentabilidade ambiental a associação que se faz entre o valor a ser cobrado e a capacidade de suporte do meio - representada na curva para cobrança pelo índice de qualidade - tendo como referência a capacidade de pagamento dos usuários de recursos hídricos. A sustentabilidade dos recursos hídricos só será base da cobrança pelo uso da água se o valor cobrado for difícil de ser pago quando esses recursos se tornarem escassos, não quando os custos de medidas mitigadoras dessa escassez tornarem-se muito elevados.

$\mathrm{Na}$ formulação, o "difícil de ser pago" é traduzido numericamente associando-se o valor da tarifa ao dobro da capacidade de pagamento do usuário quando superados aproximadamente $30 \%$ da saturação do meio. Entretanto, o fato da fórmula de cobrança possibilitar aos Comitês de Bacia flexibilidade na tomada de decisão permite a utilização deste índice de forma prospectiva. Outro nível de comprometimento dos recursos hídricos, inferior ou superior a este, pode ser adotado como medida da capacidade de recuperação do meio desde que se mantenha o crescimento exponencial da curva associado à "capacidade de não-pagamento" do usuário, isto sim fundamental à consecução dos objetivos do modelo de cobrança proposto.

Com relação aos agentes econômicos detentores de alta capacidade de pagamento, a mesma flexibilidade apresentada pela fórmula de cobrança possibilita que, a partir de análises efetuadas, os tomadores de decisão possam chegar ao extremo de definirem um grupo de usuários com um único usuário, se a capacidade de pagamento deste assim exigir. Para manter a qualidade do meio, o valor cobrado deverá sugerir a mudança de bacia a determinados usuários. Além disto, a política tarifária estará integrada aos outros instrumentos de gestão, principalmente, deverá submeter-se a uma política de outorga adequada.

O modelo proposto também contempla a associação entre sustentabilidade ambiental e racionalização econômico-financeira ao oferecer a possibilidade de adoção de uma vazão de referência com garantias estatísticas de ocorrência, obtida através dos cenários de simulação matemática de disponibilidade hídrica. A vazão de referência, ao mesmo tempo em que contribui com o viés de sustentabilidade ambiental do índice de qualidade, possibilita ao sistema de cobrança uma melhor 
alocação dos recursos e uma maior arrecadação para possíveis melhorias na infra-estrutura responsável pela quantidade e qualidade dessas vazões: quanto maior a garantia da existência de água $\rightarrow$ menor a vazão de referência $\rightarrow$ maior o preço por unidade de água consumida $\rightarrow$ maior a necessidade de racionalização do uso.

Além da vazão de referência, a modelagem matemática pode fornecer a quantificação das interferências entre os usos da água, as possibilidades advindas do manejo de reservatórios e a probabilidade de ocorrência de determinados cenários desejados. Com dados apropriados, a modelagem pode funcionar como ferramenta mais apta à representação da bacia e à localização de seus usuários, diminuindo a subjetividade do sistema de cobrança e se tornando interface adequada ao fornecimento das variáveis espaciais, quais sejam: vazões, cargas poluidoras e padrões de qualidade.

Aspecto importante do modelo de cobrança proposto é a definição de um único preço por unidade de volume para aqueles que provocam equivalente impacto ambiental poluindo ou retirando água. $\mathrm{Na}$ concepção da forma de cobrança apresentada, seja devido à poluição, seja devido à diminuição do volume, a água tem o mesmo valor monetário (K) quando atingido o mesmo grau de escassez (I). Seguindo o mesmo princípio, a utilização do padrão de qualidade no cálculo da vazão equivalente faz com que a tarifa em função da poluição não apresente valores diferentes para usuários que captam água e provocam aumento na concentração de determinado poluente daqueles que lançam este poluente e provocam o mesmo aumento de concentração.

Outras possibilidades econômicas e sociais poderão ser amplamente discutidas pela sociedade quando definidos os valores cobrados e, especificamente, o valor do multiplicador "U”. Por exemplo, determinado segmento de usuários pode ser dividido em classes, considerando fatores sociais ou econômicos, e determinada classe pode ter o valor cobrado aumentado ou diminuído para haver uma melhor distribuição de renda. Além dessa possibilidade, poderia ser incrementado o estímulo em não se ocupar áreas com escassez de recursos hídricos - associação entre uso e ocupação do solo e qualidade da água já intrínseca à metodologia base majorando-se os valores cobrados aos usuários localizados junto a corpos d'água 
cuja utilização pretendida pela sociedade seja outra ou cuja capacidade de suporte local esteja próxima do limite.

Logo, tem-se uma fórmula simples dada por "K.U.V" - multiplicação de um valor unitário de água pelo volume consumido, cujo resultado pode ser aumentado ou diminuído em função de objetivos da sociedade - e um modelo versátil, características que, juntamente com os resultados simulados, indicam facilidades na implementação do modelo. 


\section{Referências}

ALMEIDA, L. T. Política Ambiental: Uma Análise Econômica. São Paulo: Paribus, Fundação Editora da Unesp, 1998.

ALMEIDA, R.; ORSOLON, A. M.; MALHEIROS, T. M.; PEREIRA, S. R. B.; AMARAL, F.; SILVA, D.M. Planejamento ambiental: Caminho para participação popular e gestão ambiental para o nosso futuro comum - Uma necessidade, um desafio. Rio de Janeiro: Thex, 1993.

ALVES, C. M. A. A ponderação dos fatores ambientais - com uso de SIG - na localização de atividades econômicas e na cobrança pelo uso da água para irrigação. 1997. 138p. Dissertação Mestrado - EESC/USP, São Carlos.

ARAÚJO, J. C. Estudos de tarifa d'água e hidrológicos. Fortaleza: CNPq/COGERH, 1996. (Relatório Técnico, CNPq/COGERH)

ARAÚJO, J. C. Avaliação da capacidade de pagamento de irrigantes no Ceará. Fortaleza: UFC/CNPq/COGERH, 1998. (Relatório Técnico, $\mathrm{UFC} / \mathrm{CNPq} / \mathrm{COGERH})$

ARAÚJO, J. C.; SOUZA, M. P. Avaliação do sistema tarifário de água bruta no Ceará. In: XIII Simpósio Brasileiro de Recursos Hídricos. ABRH, 1999, Belo Horizonte.

ASAD, M.; AZEVEDO, L. G.; KEMPER, K. E.; SIMPSON, L. D. Management of Water Resources. Bulk Water Pricing in Brazil. The World Bank, Washington, D.C., E.U.A., 1999. (World Bank Technical Paper 432, The World Bank)

AZAMBUJA, C. Disponibilidade hídrica da bacia do rio Piracicaba - utilização do modelo MODSIMP-32. 2000. 180p. Dissertação Mestrado - EESC/USP, São Carlos.

AZEVEDO, L. G. T.; PORTO, R. L. L.; ZADEH, K. Modelos de Simulação e de Rede de Fluxo. Vol.1. ABRH, 1998.

BARRAQUÉ, B. As Políticas de Água na Europa. Lisboa: Instituto Piaget, 1995. 
BARRAQUÉ, B. Assessing the Efficiency of Economic Instruments: the Case of the French Agences de L'eau. In: Semana Internacional de Estudos sobre Gestão de Recursos Hídricos. 1999, Foz do Iguaçu.

BARTH, F. T. Aspectos institucionais da cobrança pelo uso da água. In: Workshop Cobrança Pelo Uso da Água. Belo Horizonte, 1996.

BRAGA, B.; BARBOSA, P. S. F.; NAKAYAMA, P. T. Sistemas de Suporte à Decisão em Recursos Hídricos. Revista Brasileira de Recursos Hídricos, v. 3, n. 3, p. 73-95, 1998.

BROOKSHIRE, D. S.; DALE, W. Water Resources Issues in the Developing Countries. Water Resources Research, v.29, n.7, p. 1883-1888, 1993.

CÁNEPA, E. M.; PEREIRA, J. S.; LANNA, A. E. L. A política de recursos hídricos e o princípio usuário-pagador (PUP). Revista Brasileira de Recursos Hídricos, v. 4, n.1, p. 103-117, 1999.

COSTANZA, R. Ecological economics: the science and management of sustainability. New York: Columbia University Press, 1991.

CUEVA, R. V. B. Incentivos Econômicos para a Proteção Ambiental. Saneamento Ambiental, n.14, p 32-34, 1991.

DELITTI, W. Ecologia e análise ambiental. In: TAUK, S.M. et al Análise ambiental: uma visão multidisciplinar. São Paulo: UNESP, 1995, p. 163-165.

DINAR, A.; SUBRAMANIAN, A. Water Pricing Experiences: An International Perspective. The World Bank, Washington, D.C., E.U.A., 1997. (World Bank Technical Paper 386, The World Bank)

ELLIOT, A. J. An introduction to sustainable development: the development world. London and New York: Routledge, 1994.

ENVIRONMENT AGENCY. Abstraction charges 2000-2001. United Kingdom: 2000.

FEDERAL MINISTRY FOR THE ENVIRONMENT, NATURE CONSERVATION AND NUCLEAR SAFETY. Envonmental Policy: it's our future. Water Resources Management in Germany. Germany: 1998.

FONTES, A. T. Aspectos do Macrozoneamento Utilizando SIG como Instrumento de Gestão Ambiental: Diagnósticos e Cenários Regionais no Estudo de Caso da Região de Ribeirão Preto. 1997. 67p. Dissertação Mestrado - EESC-USP, São Carlos.

GARRIDO, R. J. S. A importância da cobrança pelo uso da água como instrumento de gestão. In: Seminário Nacional de Gerenciamento de Recursos Hídricos. ABES - Seção Ceará, 1996, Fortaleza. 
GARRIDO R. Considerações Sobre a Formação de Preços para a Cobrança pelo Uso da Água no Brasil. In THAME, A. C. M. et al. A Cobrança pelo Uso da Água. São Paulo: IQUAL, 2000. p. 57-91.

GODARD, O. A gestão integrada dos recursos naturais e do meio ambiente: conceitos, instituições e desafios de legitimação. In. VIEIRA, P. F.; WEBER, J. et al. Gestão de Recursos Naturais Renováveis e Desenvolvimento: Novos desafios para a pesquisa ambiental. São Paulo: Ed. Cortez., 1997. cap. 5, p. 201-66.

HUBERT, G.; PEREIRA, J. A.; LANNA, A. E. L. Os novos instrumentos de planejamento do sistema francês de gestão de recursos hídricos: I apresentação e análise. Revista Brasileira de Recursos Hídricos, v. 7, n.2, p. 81-107, 2002.

KETTELHUT, J. T. S.; RODRIGUEZ, F. A.; GARRIDO, R. J. et al. Cobrança e outorga pelo uso da água. In: ANEEL. $O$ estado das águas no Brasil. Brasília: Agência Nacional de Energia Elétrica, 1999. $<$ hidroweb.aneel.gov.br $>$

KRAEMER, R. A. Water Management and Policy in Germany. In: Semana Internacional de Estudos sobre Gestão de Recursos Hídricos. 1999. Foz do Iguaçu.

LANNA, A. E. L. Instrumentos Econômicos de Gestão Ambiental. Porto Alegre: IPH - UFRGS, 1998. <www.iph.ufrgs.br>

LANNA, A. E. L. Hidroeconomia. In: Águas Doces do Brasil: Capital Ecológico, Uso e Conservação. São Paulo: Ed. Escrituras, 1999. cap.16.

LANNA, A. E. L. A inserção da gestão das águas na gestão ambiental. Porto Alegre: IPH - UFRGS, 2000. <www.iph.ufrgs.br>

LIVINGSTON, M. L. Designing Water Institutions: Market Failures and Institutional Response. Water Resources Management, v.9, p. 203-220, 1995.

MACHADO, P. A. L.. Direito Ambiental Brasileiro. 9a ed. São Paulo: Malheiros, 2001.

MAINOM, D. Passaporte verde: Gestão Ambiental e Competitividade. Rio de Janeiro: Qualitymark Ed., 1996.

MARTINEZ JR., F. Aplicação de Instrumentos Econômicos à Gestão Ambiental Introdução da Cobrança pela Utilização dos Recursos Hídricos no Estado de São Paulo. 1997. 253p. Tese Doutorado - Escola Politécnica-USP, São Paulo.

MORAES, A. C. R. Meio ambiente e ciências humanas. São Paulo: Hucitec, 1994. 
MOTTA, R. S. As técnicas das análises de custo-benefício na avaliação ambiental. In: TAUK, S.M. et al. Análise ambiental: uma visão multidisciplinar. São Paulo: UNESP, 1995. p. 156-162.

OECD. Environment Policy: How to Apply Economic Instruments. Paris: Organization for Economic Cooperation and Development, 1991.

PANONE, L. A.; MELlO, R. M.; SOUZA M. P.; AVOLIO, E. G. Discussão dos conceitos envolvidos no Projeto de Lei 676 do Estado de São Paulo. In: XIV Simpósio Brasileiro de Recursos Hídricos e V Simpósio de Hidráulica e Recursos Hidricos dos Países de Língua Oficial Portuguesa. ABRH, 2001, Aracaju.

PORTO, R. L.; AZEVEDO, L. G. T. Sistemas de Suporte a Decisões Aplicados a Problemas de Recursos Hídricos. In: Técnicas Quantitativas para o Gerenciamento de Recursos Hidricos. Porto Alegre: UFRS/ABRH, 1997. cap. 2, p. 43-96.

RIBEIRO, M. M. R.; LANNA, A. E. A cobrança como instrumento de gestão dos recursos hídricos brasileiros. In: Foro Interamericano de Gestón de Recursos Hídricos. 1999. Montevidéu.

RIGHETTO, G. M. Capacidade de pagamento e cobrança pelo uso e degradação dos recursos hídricos. 2001. 109p. Dissertação Mestrado - EESC-USP, São Carlos.

SACHS, I. Ecodesenvolvimento: Crescer sem Destruir. São Paulo: Vértice, 1986.

SEROA DA MOTTA, R. Utilização de Critérios Econômicos para a Valorização da Água no Brasil. Rio de Janeiro: IPEA, 1998. (Texto para discussão no 556, IPEA)

SMA. Estabelecimento de metas ambientais e reenquadramento dos corpos d'água: bacia do rio Piracicaba. São Paulo: Secretaria do Meio Ambiente, 1994. (Série Relatórios, SMA)

SOUZA, M. P. A cobrança e a água como bem comum. Revista Brasileira de Engenharia - Caderno de Recursos Hidricos, v.13, n.1, p. 25-55, 1995.

SOUZA, M. P.; ARAÚJO, J. C.; BRYANT, M. J. Diagnóstico e perspectivas do sistema tarifário de água bruta no Estado do Ceará. Fortaleza: Secretaria de Recursos Hídricos do Estado do Ceará, 1998. (Relatório Técnico, SRH)

SOUZA, M. P. Instrumentos de Gestão Ambiental: fundamentos e práticas. São Carlos: Riani Costa, 2000.

SRH. Estudos para a definição e implementação da política tarifária de água bruta no Estado do Ceará: revisão do plano de trabalho. Fortaleza: Secretaria dos Recursos Hídricos do Estado do Ceará, 2001. 
TIETENBERG, T. H. Administrando a transição para um desenvolvimento sustentável: o papel dos incentivos econômicos. In: MAY, P. H.; MOTTA, R. S. et al. Valorando a natureza: análise econômica para o desenvolvimento sustentável. Rio de Janeiro: Campos, 1994. p. 93-109.

VIEIRA, P. F. Meio ambiente, desenvolvimento e planejamento. In: Viola, E.J.; Leis, H.R.; Scherer-Warren, I. et al. Meio ambiente, desenvolvimento e cidadania: desafios para as ciências sociais. São Paulo: Cortez, 1995. p. 45-98.

WCED. Our common future. World Commission on Environment and Development. Oxford: University Press, 1987.

ZABEL, T.; REES, Y. Institutional framework for water management in the United Kingdom. In: Semana Internacional de Estudos sobre Gestão de Recursos Hídricos. ABRH, 1999, Foz do Iguaçu.

ZABEL, T.; REES, Y.; ANDREWS, K. Economic and Financial Aspects of Water Policies in Selected European Countries. In: Semana Internacional de Estudos sobre Gestão de Recursos Hídricos. ABRH, 1999, Foz do Iguaçu. 